UNIVERSIDADE DE SÃO PAULO

FACULDADE DE FILOSOFIA, LETRAS E CIÊNCIAS HUMANAS DEPARTAMENTO DE LETRAS CLÁSSICAS E VERNÁCULAS PROGRAMA DE PÓS-GRADUAÇÃO

EM LITERATURA PORTUGUESA

LUIZ CARLOS DE MOURA AZEVEDO

O QUARTO, FIGURAÇÃO DO INTIMISMO

NA POESIA DE

SOPHIA DE MELLO BREYNER ANDRESEN. 
UNIVERSIDADE DE SÃO PAULO

FACULDADE DE FILOSOFIA, LETRAS E CIÊNCIAS HUMANAS

DEPARTAMENTO DE LETRAS CLÁSSICAS E VERNÁCULAS

PROGRAMA DE PÓS-GRADUAÇÃO

EM LITERATURA PORTUGUESA

\title{
O QUARTO, FIGURAÇÃO DO INTIMISMO \\ NA POESIA DE \\ SOPHIA DE MELLO BREYNER ANDRESEN.
}

\author{
Luiz Carlos de Moura Azevedo
}

\author{
Dissertação apresentada ao Programa de \\ Pós-Graduação em Literatura Portuguesa, do \\ Departamento de Letras Clássicas e Vernáculas \\ da Faculdade de \\ Filosofia, Letras e Ciências Humanas \\ da Universidade de São Paulo, para \\ a obtenção do título de Mestre em Letras.
}

Orientadora: Profa.

Dra. Annie Gisele Fernandes 
Até agora, minhas referências eram os meus quatro pontos cardeais,

Sylvia, minha mulher,

Luís André e Paula, meus filhos,

e Estherzinha, minha mãe.

Recentemente, minha bússola ganhou mais dois braços,

Regina, minha nora, e Fabiano, meu genro.

É com a maior satisfação que dedico, aos dois, este trabalho.

Agradeço, sinceramente, aos meus professores

de pós-graduação na FFLCH,

o Prof. Dr. José Horácio do Nascimento Costa,

a Profa. Dra. Marcia de Arruda Franco

e a Profa. Dra. Viviana Bosi,

dedicados inspiradores do percurso, nem sempre ameno,

que resultou nesta dissertação.

À minha orientadora, a Profa. Dra. Annie Gisele Fernandes, sempre incansável, sempre paciente, sempre presente, um agradecimento muito especial. 


\section{RESUMO}

As operações da memória, a introspecção e a auto-representação são alguns tópicos da chamada escrita intimista, que vem desempenhando papel importante na poesia portuguesa, desde meados do século XIX. A partir de um grupo de poetas precursores, entre os quais se incluem Cesário Verde (1855/1886) e António Nobre (1867/1900), o estilo da poesia intimista continuou nos novecentos através de nomes como os de Camilo Pessanha (1867/1926), Fernando Pessoa (1888/1935), Mário de Sá Carneiro (1890/1926).

Sophia de Mello Breyner Andresen (Porto, 1919/ Lisboa, 2004), foi uma das três mais importantes vozes poéticas portuguesas da segunda metade do século XX, ao lado de Jorge de Sena (1919/1978) e de Eugénio de Andrade (1923/2005). Ela sempre apresentou recorrentes, em seus 14 livros de poesia, (o primeiro, Poesia I, de 1944), muitos dos temas caros ao intimismo: o choque entre o mundo exterior e o eu poético, a rememoração como mergulho interior, a solidão, o sofrimento provocado quando o sujeito recolhe-se dentro de si mesmo. Além disso, ela privilegia, num estilo muito particular, determinados espaços ligados à intimidade, como a casa e, em especial, o quarto.

Nossa dissertação divide-se em três capítulos - O Quarto e o Silêncio, O Quarto, a Noite e o Vazio, O Quarto Como Prisão - que enfocam o aspecto intimista da obra poética de Sophia. A discussão é centrada no sujeito poético, analisando sua posição frente ao mundo e à vida, no contexto fragmentado do pós II Guerra. Sempre na perspectiva humana de nossa finitude, frente ao horizonte da eternidade.

Palavras-chave: Sophia de Mello Breyner Andresen, poesia portuguesa século XX, intimismo, sujeito poético, análise poética. 


\section{ABSTRACT}

The so-called Intimate Poetry School flourished in Portugal by the middle of the $19^{\text {th }}$ Century, throught a group of very particular poets, like Cesário Verde (1855/1886) or António Nobre (1867/1900). Due to other outstanding poets, Camilo Pessanha (1867/1926), Fernando Pessoa (1888/1935) and Mário de Sá Carneiro (1890/1926), among others, intimate style continued on its way through the $20^{\text {th }}$ century.

Sophia de Mello Breyner Andresen (1919-2004) is recognized as one of the three most important Portuguese poets of $20^{\text {th }}$ Century's last half, the other two being Jorge de Sena (1919/1978) and Eugénio de Andrade (1923/2005). She wrote 14 poetry books since her first one, Poesia I, published in 1944.

In most of her poems, Sophia de Mello Breyner Andresen dealed with some of the innermost aspects of the poetic self, such as solitude, the remembrance of past experiences, or the aggressiveness from the outside world. She described, in several poems, the sleepingroom, this space that is a typical intimate retreat for the self.

Her poetry is always related to the human condition, in the sense that her poems encompass the joys, the sufferings and all the emotions related to our state of being human, that is, being finite and mortal, when compared to a horizon of eternity. Also, she achieved a very intimate way of describing the self's fortunate past experiences, as related to his deceptive present life.

Our Master's research, The room used as a symbol of intimate questions, in Sophia de Mello Breyner Andresen's poetry, deals mainly with three Intimate Poetry aspects that the room may present in her poems: The Room and the Silence; The Room, the Night and the Void; The Room as a Prison.

Key-words: Sophia de Mello Breyner Andresen, 20th Century Portuguese Poetry, Intimate Poetry, Poetic Self, Poetic Analysis. 


\section{SUMÁRIO}

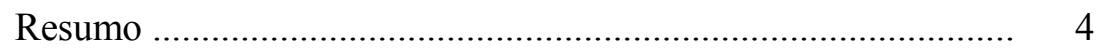

Abstract …..................................................................... 5

Introdução .........................................................................

1. O Quarto e o Silêncio ........................................................ 18

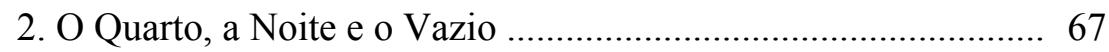

3. O Quarto como Prisão ........................................................ 108

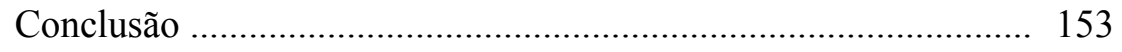

Referências Bibliográficas ........................................................ 158

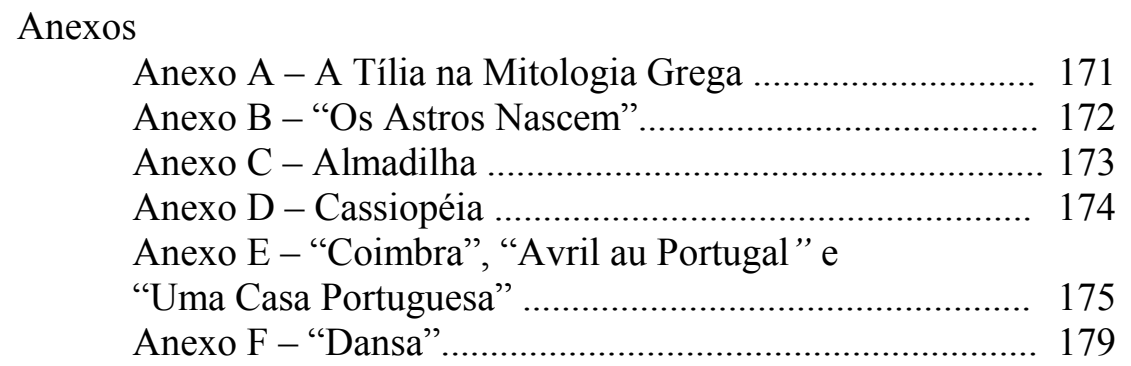




\section{INTRODUÇÃO}

Sophia de Mello Breyner Andresen (Porto, 1919/ Lisboa 2004), uma das mais importantes vozes poéticas portuguesas da segunda metade do século XX, publicou seu primeiro livro, Poesia, posteriormente chamado de Poesia I, quando tinha 25 anos, em 1944. A esse seguiram outros, num total de 14 títulos de poesia, sem contar as antologias, os contos, as histórias infantis, os ensaios e as traduções.

Ao percorrermos toda a sua obra poética, percebemos o quanto Sophia manteve-se fiel a certos temas, em especial o dilema existencial do homem, colocado entre a eternidade do cosmos e a sua própria finitude terrestre. Ela desenvolveu essa problemática valendo-se de um repertório de imagens um tanto restrito, porém constante, privilegiando cenários e elementos naturais como o mar (não só o próprio mar, mas incluindo vários itens diretamente ligados a ele: as ondas, a praia, a areia, as ilhas) ou o jardim (e seus componentes, sejam as plantas, algumas vezes individualizadas, sejam as fontes e os tanques), além do vento, dos astros (o sol, a lua, as estrelas), das nuvens.

A natureza não aparece sozinha, pois o homem está sempre marcando sua presença, por meio de sua moradia (é freqüente a menção à casa) e de suas intervenções espaciais mais elaboradas (como as cidades e, num extremo de particular simbologia, os palácios). O homem aparece muito nítido, seja através de sua postura e de seus sentimentos, frente ao que a vida lhe apresenta (temos, então, o silêncio, a solidão, a dor), seja pela descrição de suas atitudes, mesmo as condenáveis (caso da violência, da agressividade, da opressão física e política).

Esse elenco básico vem emoldurado pela sinalização da passagem do tempo, nas noites que sucedem aos dias e no ciclo das estações do ano. Ao tempo finito do homem, Sophia contrapõe a mensagem da eternidade, representada por assíduas referências, ora aos deuses da Antigüidade clássica, ora a outros personagens mitológicos.

É importante lembrar, na temática de Sophia, as cores e os perfumes, a presença das artes plásticas e de personagens históricos. Os poetas são continuamente evocados, inclusive os contemporâneos.

Enfim, um traço seu bastante particular é a assídua referência às coisas, celebrando epifanicamente a realidade visível. Nesse sentido da celebração do real, cumpre mencionar uma famosa série de textos, intitulados "Arte Poética", nos quais 
Sophia procura formular uma "explicação" para sua própria poesia. Reproduzimos, a seguir, um trecho de "Arte Poética II", do livro Geografia, cuja primeira edição é de 1967:

Pois a poesia é a minha explicação com o universo, a minha convivência com as coisas, a minha participação no real, o meu encontro com as vozes e as imagens. Por isso, o poema não fala de uma vida ideal mas sim de uma vida concreta: ângulo da janela, ressonância das ruas, das cidades e dos quartos, sombra dos muros, aparição dos rostos, silêncio, distância e brilho das estrelas, respiração da noite, perfume da tília e do orégão. (ANDRESEN, 1999, p. 95)

Sophia deixa bem clara "a minha participação no real", insistindo que "o poema não fala de uma vida ideal mas sim de uma vida concreta". Para a poeta, portanto, mais que uma proposta idealizada, provavelmente utópica e distante de tudo o que o homem verdadeiramente sente, o que importa é uma atitude frente a frente com tudo o que nos cerca, encarando esta realidade como próprio motor de nossa vida.

Vejamos os elementos citados por Sophia. No caso da "janela", das "ruas, das "cidades", dos "quartos", dos "muros", verificamos que todos constituem exemplos da interferência humana sobre o cenário natural. O "ângulo", a "ressonância" e a "sombra" não são meros detalhes, mas recursos eloqüentes que colorem os poemas de maneira, podemos dizer, muito viva, agregando elementos geométricos, recursos sonoros e de luz. Quanto às "estrelas", notamos que elas estão realçadas tanto pela "distância", evidenciando seu caráter eterno, contraposto à qualidade mortal do homem, como pelo "brilho", o que enfatiza a perenidade.

A "aparição dos rostos" sublinha a própria existência do homem, enquanto o "perfume da tília e do orégão" exalta e sacraliza a natureza, através de uma característica peculiar. $\mathrm{Na}$ "respiração da noite", Sophia utiliza a antropomorfização, solução estilística recorrente em sua poesia, para destacar a primazia conferida ao ambiente noturno, como inspirador do recolhimento do sujeito para dentro de si próprio, graças às condições favoráveis de "silêncio" e de pouca luminosidade. 
São detalhados, assim, os vetores da "vida concreta" sempre valorizados por Sophia, de modo a enfatizar as coisas como componentes essenciais, ao lado do homem, da realidade do mundo.

Nesse sentido, alguns estudos sobre Sophia costumam definir a sua poesia como uma poesia do concreto, caso da professora brasileira (e também poeta) Vilma Arêas, na introdução a Poemas escolhidos - Sophia de Mello Breyner Andresen, uma antologia publicada no Brasil em 2004.

Após assinalar a proximidade poética entre Sophia e dois poetas portugueses seus contemporâneos, Eugénio de Andrade e Jorge de Sena (o trio certamente representa o que de melhor aconteceu na poesia portuguesa, imediatamente após a II Guerra), a professora Arêas cita o brasileiro João Cabral de Mello Neto, outro nome conhecido pela concretitude de sua poesia:

[Os três poetas, Sophia, Eugénio de Andrade e Jorge de Sena] reagiram ao esgotamento de certa poesia neo-realista nos fins da década de 40 , elegendo a "secura" da composição à semelhança de João Cabral de Melo Neto, cuja "mineralidade", paradigma de sua poética, constitui o domínio metafórico preferido de Sophia, com sua pedra, conchas, sal e cristais do mar. (ARÊAS, 2004, p. 19)

Outro que lembra o aspecto concreto da poesia de Sophia é o professor português Carlos Reis, em ensaio de 2005, no qual, após mencionar os mesmos Eugénio de Andrade e Jorge de Sena, salienta a militância cívica de Sophia, que participou da resistência ao regime do ditador António de Oliveira Salazar, criou poemas sobre a Revolução de Abril e, no governo instaurado após esse movimento, foi eleita deputada à Assembléia Constituinte, pelo Partido Socialista.

O ensaio de Reis primeiramente lembra a estréia poética dos três, Sophia, Eugénio e Sena, em Cadernos de Poesia, revista editada de maneira intermitente, entre 1940 e 1953, considerada um marco na divulgação da poesia portuguesa e na revelação de novos poetas.

Justamente de autenticidade poética, acima de feudos políticos ou ideológicos (mas não, quando foi o caso, à margem de intervenções cívicas), pode falar-se a propósito de Sophia de Mello Breyner Andresen, de Jorge de Sena ou de Eugénio de Andrade, consagrados pela crítica e pela história literária como os vultos fundamentais que, a partir de uma quase iniciação nos Cadernos de Poesia, prolongaram a sua poesia por várias décadas. (REIS, 2005, p. 114) 
Mais adiante, após destacar o valor de Sophia, Reis aponta a "concreção" verificada em sua obra poética, embora se referira, de forma um tanto vaga, à "moderna poesia portuguesa":

É difícil dizer com brevidade o quanto [Sophia] significa para a moderna poesia portuguesa e como foi assumindo a dimensão incontornável que hoje tem, na [...] história literária [portuguesa]. [Nos seus livros de poesia] desenvolve-se um trajecto poético extremamente exigente e suportado por diversas linhas de força: uma concepção da poesia como factor de concreção de uma perfeição ausente e perdida; o entendimento do poema como entidade natural e anterior ao dizer do poeta [...] e como arte anterior a todas as artes; o culto da linguagem poética como enigmática revelação de uma verdade oculta (também por isso, ela declarou, em fórmula que ficou lapidar, "que a poesia não se explica, a poesia implica"), num trajecto em que ao poeta cabe descobrir a identidade latente que se oculta sob "o nome das coisas".(REIS, 2005, p. 114)

Foi esse "nome das coisas" que inspirou o próprio título de um dos livros de Sophia, o décimo de poesia, $O$ nome das coisas, de 1977. Além disso, numa demonstração de como é representativo de toda a sua obra poética, foi exatamente como Il nome delle cose que foi editada na Itália, em 1983, uma antologia de toda sua obra poética até então, traduzida pelo poeta Carlo Vittorio Cattaneo.

Ora, para Sophia, referir-se ao "nome das coisas" significa, talvez, a melhor evidência de sua extrema preocupação com a ênfase no lado real e concreto da vida, assinalando, ao mesmo tempo, a importância da existência do homem sobre a terra. É o que se passa, por exemplo, em "Coral", com apenas três versos, mas que por resumir admiravelmente essas idéias básicas da poesia de Sophia, constitui um de seus poemas mais citados.

"Coral" abre a segunda parte de seu terceiro livro de poesia, também intitulado Coral, originalmente editado em 1950:

Ia e vinha

E a cada coisa perguntava

Que nome tinha. (ANDRESEN, 2001, p. 193).

Muito se tem discutido sobre esse poema, inclusive sobre a possibilidade de um significado para seu título "Coral", que, como já dissemos, é o mesmo do livro no qual foi incluído. Argumenta-se, por exemplo, se "Coral" estaria se referindo ao animal celenterado marinho que leva esse nome; ou a um outro animal, desta vez 
réptil, a cobra-coral; ou a um grupo de vozes que cantam em conjunto; ou mesmo a todas essas hipóteses. Ao nosso ver, não são esses detalhes que interessam, mas sim o que podemos encontrar diretamente no poema, através de uma leitura atenta de seus três versos, curtos e incisivos.

O sujeito é mencionado na terceira pessoa do singular, o que claramente indica uma generalização. Ao descrever movimento de "ia e vinha", Sophia pode estar se referindo à indecisão, tão característica do homem, perplexo frente ao mundo, o qual lhe aparece, muitas vezes, complexo e estranho. O verbo "perguntava", por sua vez, assinalaria a falta de conhecimento do homem, incapaz de resolver o próprio mistério da vida, pronto a perguntar a "cada coisa" o seu "nome", para tentar conhecer melhor o mundo no qual vive, numa atitude que vem reforçar o conceito da diminuta dimensão humana.

Ora, o movimento de ir e vir recorda, também, o ciclo eterno das marés nas praias, evidenciando a força da natureza e o tamanho infinito do mar, novamente em comparação à finitude humana. Admitindo-se essa analogia marinha, fica mais fácil entender o título do poema como uma alusão ao animal coral, que possui uma simbologia específica, ligada tanto à sua origem mitológica (ele teria nascido do sangue da Górgona Medusa vertido sobre o mar, após ela ter sido decapitada por Perseu, como veremos no decorrer da dissertação), como a uma de suas colorações mais típicas, o vermelho (associando-o, mais uma vez ao sangue). De qualquer maneira, o coral é um material considerado precioso, com o qual são confeccionadas jóias muito apreciadas, utilizadas como amuleto em algumas culturas.

O "ia e vinha" poderia, outrossim, ser associado à locomoção de um réptil. Não seria razão igualmente válida para optarmos pela cobra-coral como justificativa para o título do poema?

Enfim, e isto é o que importa, “Coral” aponta a relevância da nomeação das “coisas", não só no âmbito restrito do poema, mas na obra poética de Sophia e, de forma ainda mais abrangente, como atitude fundamental para o homem tomar conhecimento da realidade que o cerca. Nesse sentido, nada como dar palavra a uma outra poeta portuguesa da segunda metade do século 20, mas de uma geração posterior, Fiama Hasse Pais Brandão. Num texto em homenagem à Sophia, de 1988, referindo-se aos versos "Arranco o mar do mar e ponho-o em mim/ E o bater do meu coração sustenta o ritmo das coisas" (ANDRESEN, 2001, p. 164), do poema "As Minhas Mãos", também de Coral, Fiama faz esta confissão: "Eis a aprendizagem 
fundamental: chamar $E u$ às coisas, minha primeira dívida a Coral” (BRANDÃO, 1988, p. 80).

Em primeiro lugar, encontramos, nessa assertiva de Fiama, um certo eco do que Fernando Pessoa escreveu sobre Antonio Nobre, quase cem anos atrás, no texto "Para a Memória de António Nobre":

De António Nobre partem todas as palavras com sentido lusitano que de então para cá têm sido pronunciadas. Têm subido a um sentido mais alto e divino do que ele balbuciou. Mas ele foi o primeiro a pôr em europeu este sentimento português das almas e das coisas, que tem pena de que umas não sejam corpos, para lhes poder fazer festas, e de que outras não sejam gente, para poder falar com elas. (PESSOA, 1915)

Além disso, as palavras de Fiama definem com perfeição o pronunciado intimismo que encontramos na poesia de Sophia - da mesma forma, poderíamos acrescentar, como o texto de Pessoa também aponta certas tendências intimistas de Nobre.

Os versos de "As Minhas Mãos”, o poema de Sophia citado por Fiama, mostram um sujeito em comunhão tão completa com o universo que o circunda, a ponto de essa aliança envolver o "bater" do "coração" dele, sujeito. Na verdade, "As Minhas Mãos” é realmente um poema belíssimo e merece ser reproduzido por inteiro:

As minhas mãos mantêm as estrelas,

Seguro a minha alma para que se não quebre

A melodia que vai de flor em flor,

Arranco o mar do mar e ponho-o em mim

E o bater do meu coração sustenta o ritmo das coisas. (ANDRESEN, 2001, p. 164)

A presença do sujeito é reiterada em quatro dos cinco versos, pelos possessivos "minhas", “minha", "mim", "meu”. Ao mesmo tempo, o segundo e o quarto versos iniciam-se pelos verbos "seguro" e "arranco", conjugados na primeira pessoa do singular e indicativos de ações, podemos dizer, fortes, intensas, mais uma enfatizando a impositiva presença do eu-sujeito. $\mathrm{O}$ mar, grande força da natureza, 
sempre privilegiada pela poesia de Sophia, como teremos oportunidade de observar no decorrer desta dissertação, sublima o desejo de união com o universo. A mesma natureza, através de outro de seus elementos, as flores, vem ainda lembrada no verso central, de certa forma isolado por seu tamanho menor e que recorda, através da referência à "melodia”, uma das características mais específicas da própria poesia.

Além da natureza e da poesia em si, “As minhas mãos" traz, também, outros dos ingredientes muito caros à Sophia, desta vez do cosmos: "as estrelas", que são referidas no primeiro verso e, como notamos acima, participam daquele elenco de componentes da "vida concreta" citados pela poeta em "Arte Poética II", "distância e brilho das estrelas".

$\mathrm{Na}$ verdade, ao seguirmos o percurso poético de Sophia, lendo os poemas de todos os seus livros, percebemos nitidamente o quanto ela foi fiel e constante em relação a certos temas e assuntos. O conceito de fidelidade, aliás, foi notado pela professora Arêas:

Penso em um nome que emblematicamente resuma o ofício e a oficina de Sophia. Escolho dois: "bravura" e "resistência". Mas também "fidelidade", que faz com que poemas, prosas e ensaios repercutam uns nos outros. (ARÊAS, 2004, p. 23).

Ao comentar essa constância de Sophia, o poeta brasileiro Sérgio Alcides, na resenha que fez da antologia Poemas escolhidos, optou por falar em "regularidade", citando vários dos elementos aos quais já nos referimos:

Numa obra que se prolongou por mais de 50 anos, [Sophia] mantém de ponta a ponta uma impressionante regularidade. Segue em linhas gerais o mesmo curso, perseguindo sempre os mesmos temas e imagens: o mar, o universo, a tensão entre o tempo e a eternidade, a epifania que equilibra a finitude humana e a perenidade do cosmos. (ALCIDES, 2004, p. 38)

Como vimos observando, o contraste entre a "a finitude humana e a perenidade do cosmos" é um dos pontos-chave da poesia de Sophia. Em “As Minhas Mãos”, poema que acabamos de mencionar, o mar, metáfora do infinito e do eterno, aparece em oposição à fragilidade do sujeito - e do próprio homem -, claramente expressa no segundo verso, "Seguro a minha alma para que não se quebre". Note-se que essa fragilidade envolve, inclusive, aquela porção humana tida como imortal, a "alma".

A persistente identificação entre o eu-poeta e a realidade que o circunda, constante em Sophia, conforme Fiama Hasse Pais Brandão tão bem soube destacar, 
vai se manifestar de maneira muito perceptível, através de toda sua obra poética, pela repetição assídua de determinados cenários, ambientes e elementos, pelos quais a poeta evidenciou sua predileção, ao relacioná-los explicitamente no trecho de "Arte Poética II", que voltamos a citar: "ângulo da janela, ressonância das ruas, das cidades e dos quartos, sombra dos muros, aparição dos rostos, silêncio, distância e brilho das estrelas, respiração da noite, perfume da tília e do orégão".

Portanto, é nas palavras da própria Sophia que sentimos a identificação da poeta com alguns dos elementos mais característicos da chamada literatura intimista, como o "silêncio", estado que salienta a solidão e o isolamento ${ }^{1}$ do sujeito. Ou os "muros", representando um obstáculo considerável entre o eu e a sua apreensão do mundo. E mais, a "distância" que nos separa das "estrelas", símbolo do infinito do universo frente à minúscula dimensão do homem, marcado pelo seu destino de mortal. Também a "noite", espaço de tempo favorável aos sonhos, aos devaneios, à fuga da realidade.

No conjunto de a obra poética de Sophia, a reiteração assídua desses tópicos, somada ao realce da agitação das "ruas" e da desordem das "cidades", em oposição ao ambiente fechado dos "quartos" (ou ao caráter sagrado das casas), vai indicando, poema a poema, a grande afinidade da poeta com as características que compõem o estilo intimista, modo literário no qual a ênfase recai sobre o "eu" que escreve, assinalando suas recordações e memórias como forma de mergulho interior, expressando suas dores e tormentos pessoais através da angústia provocada pela introspecção, vivenciando, enfim, todo o choque entre o mundo exterior e a aflição íntima provocada pelo isolamento dentro de si mesmo.

Entre todos esses elementos, o quarto ocupa uma posição de relevo, na poesia de Sophia. Como tentaremos mostrar nesta dissertação, o quarto, ambiente extremamente propício para o sujeito poético encontrar-se consigo mesmo, combinado com outros ingredientes caros à poeta (muitas vezes elementos internos, como as paredes e muros, as portas e janelas, mas também externos, como o terraço, o

\footnotetext{
1 A respeito do isolamento, diz a professora portuguesa Clara Rocha, em Máscaras de narciso, sobre Robinson Crusoe, o personagem náufrago do escritor inglês Daniel Defoe que se vê sozinho numa ilha: "[Ao] estar insulado, isolado [,] todo o autobiógrafo tem um pouco de Robinson. O seu interlocutor imediato é ele mesmo. [O poeta francês Paul] Valéry dá o título de Le Robinson pensif às reflexões sobre a comunicação do eu consigo próprio. E a figura de Robinson insinua-se na escrita intimista como modelo desse diálogo/monólogo, em que se cruzam as vozes dum eu dividido por força de seu isolamento, da sua inquietação" (ROCHA, 1992, p. 56). Lembremos ainda que, a propósito da relação entre o isolamento e a ilha, Ilhas é o título do décimo segundo livro de poesia de Sophia, lançado em 1990 .
} 
jardim, o mar, o céu), ou substituído por cenários equivalentes (caso das grutas, no texto poético "As Grutas"), torna-se bastante emblemático do intimismo muito particular de Sophia, no qual o eu poético afirma-se como componente real e importante de um universo do qual se vê, muitas vezes, exilado.

$\mathrm{O}$ aspecto intimista da poesia de Sophia encaixa-se num viés mais recente de estudo da literatura portuguesa, que analisa a literatura do eu como tendência que se acentuou a partir de meados do século XIX, configurando uma geração de precursores como Antero de Quental (1842/1891), Cesário Verde (1855/1886) e António Nobre (1867/1900). A partir do início do século XX, encontramos características intimistas na produção de poetas tão diferentes quanto Camilo Pessanha (1867/1926), Manuel Laranjeira (1877/1912), Florbela Espanca (1884/1930), Fernando Pessoa (1888/1935), Mário de Sá Carneiro (1890/1926), Irene Lisboa (1892/1958). Mais para o fim dos novecentos, continua a escrita íntima na obra de poetas portugueses, tais como, para citar apenas quatro exemplos, Miguel Torga (1907/1995), Alexandre O’Neill (1924/1986), Luiza Neto Jorge (1939/1989), ou mesmo Fiama Hasse Pais Brandão (1938/2007).

Em alguns desses autores, a escrita do eu expressou-se, também, através de diários, vide o Diário íntimo (edição póstuma, 1952) de Laranjeira, o Diário do último ano (editado também após a morte da autora, em 1981) de Florbela, o Livro do desassossego (publicação igualmente póstuma, 1982) de Pessoa, através de seu heterônimo Bernardo Soares, ou o Diário (em doze volumes, lançados a partir de 1941) de Miguel Torga.

Há opiniões que chegam a comparar Sophia a Camilo Pessanha, como faz a professora Arêas no texto que vimos citando, no qual, aliás, ela frisa a predileção de Sophia pelo espaço do quarto:

O espaço interno, do quarto, volta-se inteiramente para fora, para a luz, levando-nos a evocar o léxico particular de Sophia que experimenta tramas de sombra e de claridade nas coisas e na paisagem, numa nuance de transparências que parecem inspiradas, não fossem os contornos muito marcados, na paleta de Camilo Pessanha. (ARÊAS, 2004, p. 18).

Quanto a Cesário Verde, Sophia homenageou-o no livro Ilhas, num poema justamente intitulado "Cesário Verde", cuja segunda estrofe descreve a profunda angústia do sujeito, em contraposição à agitação da cidade, numa referência clara a " $\mathrm{O}$ Sentimento dum Ocidental" (VERDE, 1945, p. 101), de O livro de Cesário Verde cuja 
primeira edição, póstuma, é de 1887. Esta é a segunda estrofe do poema "Cesário Verde":

(...)

Porém nas roucas ruas da cidade

A nítida pupila se alucina

Cães se miram no vidro da retina

E ele vai naufragando como um barco

(...) (ANDRESEN, 1999, p. 339)

Sophia descreve os olhos do sujeito poético como se fossem uma janela, intermediários entre ele e o mundo. Janela não totalmente aberta, mas interceptada por um obstáculo, o "vidro da retina", no qual se refletem os "cães", imagem suficientemente aterradora para provocar o naufrágio do sujeito poético.

Voltaremos a "Cesário Verde" no Capítulo 2, quando o poema será reproduzido na íntegra e analisado em detalhe. Por enquanto, gostaríamos de notar que o verso que se refere à "retina" lembra um famoso verso de Camilo Pessanha, “Imagens que passaes pela retina” (PESSANHA, 1994, p. 112), que abre um dos poemas de Clepsidra, livro publicado pela primeira vez em 1920.

Quanto ao naufrágio, sugerido no último verso da estrofe, trata-se de imagem muito recorrente no final do século XIX. Além disso, o sujeito naufragado, ou seja, fragilizado, isolado, perdido, é o sujeito solitário, típico da literatura intimista, como nestes livros de dois daqueles poetas portugueses da virada do século XIX para o XX, nos quais a solidão aflora a partir do título: Só de António Nobre, de 1892, ou Commigo (versos d'um solitário), de Manuel Laranjeira, de 1912. Isso se verifica também em Irene Lisboa, cujo livro Solidão, de 1939, é considerado, pelo ensaísta e professor português Jacinto do Prado Coelho "talvez a sua obra-prima" (COELHO, 1979, p. 37). Postumamente, em 1975, Irene teve editado Solidão II.

No caso específico de Sophia, ao analisarmos, em detalhe, cada uma das ocorrências do quarto, foi possível estabelecer três padrões principais, ligando o quarto a questões específicas do intimismo:

\section{O Quarto e o Silêncio.}

\section{O Quarto, a Noite e o Vazio.}




\section{O Quarto como Prisão.}

Nessa perspectiva, foram definidos os três capítulos desta dissertação, cada um incluindo um grupo de poemas de Sophia, estudados a partir dos elementos que podem contribuir para entender o intimismo presente em sua obra poética. O foco é sempre no espaço do quarto e, segundo o poema, surgem menções a outros espaços e ingredientes típicos do intimismo, alguns dos quais já citamos mais de uma vez nesta Introdução, como a casa, a gruta e o jardim, além da janela, da parede, do muro, da janela e do espelho.

Gostaríamos de frisar que os três capítulos não constituem ensaios isolados entre si, mas, devido à própria recorrência de temas, elementos e, mesmo, termos, na totalidade da poesia de Sophia, estão constantemente remetendo-se uns aos outros.

O corpo dos poemas de Sophia foi estudado a partir dos três volumes de sua Obra poética, da editora portuguesa Caminho, com exceção dos poemas de $O$ búzio de Cós e outros poemas, que consultamos na edição da Caminho, de 2007. . Cumpre informar que essa editora deixou de publicar os três volumes da Obra poética, passando a reeditar individualmente, a partir de 2003, cada um dos 14 títulos de poesia de Sophia. 


\section{O QUARTO E O SILÊNCIO.}

O poema escolhido para iniciar este capítulo é "Manuel Bandeira", homenagem de Sophia ao poeta brasileiro e originalmente publicado em Geografia, livro de 1967. Nossa escolha se justifica pela atitude tipicamente intimista na qual se coloca o sujeito, em especial pelo estado de silêncio, enfatizado logo a partir da primeira estrofe.

Além do silêncio, "Manuel Bandeira" apresenta outros elementos do intimismo, reiterados por Sophia através de toda a sua obra poética, como é o caso das operações da memória, do recolhimento do sujeito para dentro de si, do contraste verificado entre a escuridão sombria dos interiores, em oposição à luminosidade "transparente" do exterior. Também a recordação da infância como um tempo mais feliz, além da sinalização da passagem do tempo finito do homem, contraposto ao ciclo perene da natureza.

O poema, enfim, dedica significativa importância aos espaços de proteção e abrigo do sujeito, necessários não só como amparo contra as constantes ameaças externas, mas, muitas vezes, como locais favoráveis à introspecção e ao mergulho íntimo. Estamos nos referindo à "casa", identificada em "Manuel Bandeira" como "antiga", característica que reforça o seu valor protetor; e, de maneira particular, ao "quarto", objeto primeiro de nossa dissertação, definido pelo próprio sujeito como "pleno de futura/ Saudade".

Vale assinalar que este poema interessa muito de perto ao leitor brasileiro, pois além do tributo que presta ao poeta que é considerado um dos ícones do nosso modernismo, menciona três de suas obras fundamentais, seja pelo que representam dentro da linguagem modernista, seja pelo que proporcionam em termos de prazer lúdico (caso de "A Balada das Três Mulheres do Sabonete Araxá" e “Trem de Ferro"), ou mesmo pelo seu caráter predominantemente intimista, característica de peso específico para este trabalho, que encontramos em "Poema do Beco".

Vamos a "Manuel Bandeira":

Este poeta está

Do outro lado do mar

Mas reconheço sua voz há muitos anos

E digo ao silêncio seus versos devagar 
Relembrando

$\mathrm{O}$ antigo jovem tempo quando

Pelos sombrios corredores da casa antiga

Nas solenes penumbras do silêncio

Eu recitava

"As três mulheres do sabonete Araxá"

E minha avó se espantava

Manuel Bandeira era o maior espanto da minha avó

Quando em manhãs intactas e perdidas

No quarto já então pleno de futura

Saudade

Eu lia

A canção do "Trem de ferro"

E o "Poema do beco"

Tempo antigo lembrança demorada

Quando deixei uma tesoura esquecida nos ramos da cerejeira

Quando

Me sentava nos bancos pintados de fresco

E no junho inquieto e transparente

As três mulheres do sabonete Araxá

Me acompanhavam

Tão visíveis

Que um eléctrico amarelo as decepava.

Estes poemas caminharam comigo e com a brisa

Nos passeados campos da minha juventude

Estes poemas poisaram a sua mão sobre o meu ombro

E foram parte do tempo respirado (ANDRESEN, 1999, p.78)

A lembrança que o sujeito tem de Manuel Bandeira está ligada ao "silêncio", no qual os "seus versos" são ditos "devagar", indicando o caráter de profunda 
introspecção, sentimento logo a seguir reforçado pelo ambiente doméstico escolhido para recitar o poeta brasileiro, os "sombrios corredores da casa antiga", com suas "solenes penumbras". A introspecção começa a ser sinalizada pelo "relembrando", vocábulo que significativamente aparece isolado, iniciando a segunda estrofe. Este relembrar, ação na qual o eu recorda sua própria memória, acontece num ambiente de sombras, escuridão e "penumbras", reforçando, muito a propósito, o caráter de interioridade, percebido desde o início do poema. Além disso, por ser mencionado duas vezes, no quarto e no oitavo versos, fica clara a importância do silêncio, para esta operação de mergulho em si mesmo.

Antes de nos determos, em maior detalhe, sobre os "sombrios corredores" e suas "solenes penumbras", convém abordar o cenário mais amplo onde ambos se localizam, a "casa antiga" que, justamente por sua antigüidade, mantém uma relação de familiaridade íntima com o sujeito.

É conhecida a obsessão de Sophia pelo tema da casa, presença constante em seus poemas, desde seu primeiro livro, Poesia I, de 1944, e componente do título de uma das subdivisões de um de seus livros: “A Noite e a Casa” é a terceira parte de Geografia, que inclui "Manuel Bandeira" em sua sexta parte, esta chamada "Brasil ou do Outro Lado do Mar”. Também a primeira parte de Dual, nono livro de poesia da autora, lançado em 1972, chama-se “A Casa”, mesmo título de seu poema de abertura.

Ora, a casa significa não só um dos símbolos mais evidentes de abrigo seguro contra as intempéries, como constitui, para o homem, defesa e "estabilidade" expressão utilizada pelo filósofo Gaston Bachelard, em sua definição da casa como um dos "espaços de estabilidade do ser" (BACHELARD, 1988, p. 114), frente aos perigos e adversidades do mundo exterior. Ou, como afirma Hans Biedermann, em seu Dicionário ilustrado de símbolos: "ponto de cristalização para a formação das diversas conquistas da civilização, [a casa é] símbolo do próprio homem, que [nela] encontrou seu lugar estável no Cosmo (BIEDERMANN, 1993, p. 76).

Vejamos o poema “As Casas", de Dia do mar, segundo livro de poesia de Sophia, de 1947, no qual o sujeito se refere, especificamente, às casas "em que eu vivo". Essa clara assertiva reforça, através da posse, a intensa intimidade com o espaço:

Há sempre um deus fantástico nas casas

Em que eu vivo, e em volta dos meus passos 
Eu sinto os grandes anjos cujas asas

Contêm todo o vento dos espaços. (ANDRESEN, 2001, p. 141)

Como, no mesmo verso no qual o pronome pessoal "eu” é citado, aparece, logo a seguir, o pronome possessivo "meus", referindo-se aos "passos", o efeito conseguido é o de uma ênfase adicional no sentimento de posse, acentuando o caráter íntimo. A intimidade, na verdade, é ainda reiterada pelo verbo viver, conjugado na primeira pessoa do singular, "eu vivo". Percebemos, em conseqüência, que o verso encontra-se totalmente centrado no "Eu", inclusive pelo fato de a maior amplitude espacial alcançada ser, apenas, "em volta dos meus passos".

Quanto à profunda relação entre a casa e seu morador, é interessante recorrer a “Uma Casa para Ler e Deitar”, ensaio do professor Edgard Pereira, incluído em Escrever a casa portuguesa, livro organizado pelo professor Jorge Fernandes da Silveira. Embora o artigo refira-se, especificamente, ao poeta português Helder Moura Pereira, as considerações gerais sobre a casa que, inclusive, citam o filósofo Emmanuel Lévinas, encaixam-se, perfeitamente, no contexto da poesia introspectiva de Sophia:

Espaço exemplar da representação da privacidade e do recolhimento, a casa constitui o lugar privilegiado em que o sujeito se abriga e inicia sua relação com o mundo. Nas palavras de Lévinas, "o papel privilegiado da casa não consiste em ser o fim da atividade humana, mas em ser a sua condição e, nesse sentido, o seu começo. $\mathrm{O}$ recolhimento necessário para que a natureza possa ser representada e trabalhada, para que se manifeste apenas como mundo, realiza-se como casa". Nada mais natural, portanto, que a casa e seus objetos funcionem como metonímias de estados e emoções do sujeito que a habita. Nesse sentido aponta esta reflexão de Lévinas: "O movimento pelo qual um ser constrói a sua casa abre-se e garante a interioridade, constituindose num movimento pelo qual o ser separado se recolhe. $O$ nascimento latente do mundo dá-se a partir da morada"1. (PEREIRA, 1999, p. 496; grifo meu)

No poema "As Casas", esse lugar privilegiado (que se torna ainda mais singularizado pelo próprio título) aparece como um espaço sagrado, pois habitado por "um deus fantástico", não um deus qualquer, pois vem qualificado claramente como “fantástico". A sacralização completa-se pela menção aos anjos, personagens assíduos nos poemas de Sophia e que, neste poema, apesar de acompanharem o sujeito de perto, lembram a ele a vastidão de tudo o que é exterior à casa, vastidão aqui representada pelo vento, força da natureza muitas vezes evocada por Sophia.

\footnotetext{
${ }^{1}$ O livro de Lévinas citado por Edgard Pereira é Totalidade e infinito, p. 63 e p. 90.
} 
Vem a propósito o conceito do "espaço sagrado da casa", formulado por Mircea Eliade e aproveitado por Leland Robert Guyer, em sua tese de doutoramento na Universidade da Califórnia, Santa Bárbara, Imagística do espaço fechado na poesia de Fernando Pessoa:

[Uma] útil abordagem da casa como uma imagem arquetípica é a do historiador religioso Mircea Eliade [que em $O$ sagrado e o profano: $a$ essência das religiões] foca particularmente bem este tópico. [...] Estabelece o espaço sagrado da casa em oposição ao espaço profano, exterior à casa. De acordo com a identificação junguiana do processo da auto-realização ou individuação, Eliade descobre que o homem possui “[...] uma inextinguível sede ontológica. O homem religioso é sedento do ser. O terror diante do 'Caos' que envolve seu mundo habitado corresponde ao seu terror diante do nada" . O seu sacro mundo habitado no qual o homem encontra a realidade do seu ser e muitas vezes o objectivo da sua existência é o templo, ou a sua contrapartida secular tendendo para o sagrado, a casa (GUYER, 1982, p. 2627).

Não pretendemos nos estender demais sobre a casa, pois esta dissertação refere-se ao espaço do quarto. No entanto, já que falamos sobre a sacralização da moradia, vale uma referência ao poema "Habitação", do livro Ilhas, de 1989:

Muito antes do chalet

Antes do prédio

Antes mesmo da antiga

Casa bela e grave

Antes de solares palácios e castelos

No princípio a casa foi sagrada -

Isto é habitada

Não só por homens e por vivos

Mas também pelos mortos e por deuses

Isso depois foi saqueado

Tudo foi reordenado e dividido

Caminhamos no trilho

De elaboradas percas

Porém a poesia permanece

\footnotetext{
${ }^{2}$ ELIADE, 1992, p. 56.
} 
Como se a divisão não tivesse acontecido

Permanece mesmo muito depois de varrido

O sussurro de tílias junto à casa da infância (ANDRESEN, 1999, p.

311)

O travessão, finalizando o sexto verso da primeira estrofe, enfatiza exatamente a idéia da casa como espaço sagrado, já que ela foi, primitivamente, "habitada/ (...) também pelos mortos e pelos deuses". O "No princípio", sugere um tempo imemorial, no qual reinava a perfeição, antes de ocorrer a "divisão" - o que remete à idéia do homem moderno como um ser exilado, expulso da totalidade do universo, à qual não tem acesso. Afinal, só lhe resta o "trilho/ De elaboradas percas", cabendo ao leitor pouco familiar com o vocabulário exigente de Sophia concluir que "percas" aqui não se refere a um peixe, mas a "perdas".

Ou, como disse a propósito dessa "divisão", , a professora portuguesa, também poeta, Maria de Lourdes Belchior, num artigo de 1986 para a revista Colóquio/Letras:

Desde sempre se contrapõe, [na poesia de Sophia], à imagem de um tempo dividido que o homem vive como tempo de ameaça, tempo de ódio, tempo de nojo, a ambição de uma linha imaginária não quebrada, de um tempo absoluto, sem limites. [...] Esta demanda de um tempo puro, na procura da unidade, tem raízes fundas em sua poesia. [...] O "puro espaço" e a "lúcida unidade" [conforme o poema "Liberdade", de Mar novo] procura-os Sophia a todo transe. Puro espaço e lúcida unidade serão equivalência de absoluto por oposição a dividido, efêmero. (BELCHIOR, 1986, p. 36 e 39; grifos da autora)

No entanto, nem tudo está perdido: “a poesia permanece”, esperança sinalizada na última estrofe, envolta por elementos, como a "casa da infância", que lembram o poema "Manuel Bandeira", no qual aquelas "mulheres do sabonete Araxá", "Tão visíveis", seriam uma evidência concreta da permanência da poesia, em oposição ao aspecto finito, tanto do homem, como do mundo construído por ele.

Encontramos, em "Habitação", outros ecos de "Manuel Bandeira", como a primeira referência à "casa", que a define como "antiga". Por outro lado, ainda em "Habitação", as "tílias" do último verso, cujo "sussurro" realça o clima de silêncio, individualizam a vegetação de um determinado jardim ou quintal, de maneira a particularizá-lo como lembrança pessoal do sujeito, gravada em sua memória, exatamente como as "cerejeiras" de "Manuel Bandeira".

\footnotetext{
${ }^{3}$ Vale assinalar que No tempo dividido é o título do quarto livro de poesia de Sophia, lançado em 1954.
} 
A referência às tílias lembra a mitologia grega, que menciona essa árvore em pelo menos duas lendas. Uma refere-se ao casal de camponeses frígios Filêmon e Baucis, esta transformada em tília pelos deuses, como resposta ao pedido do casal de permanecerem eternamente juntos, sendo Filêmon convertido num carvalho, ambos postados defronte à antiga casa deles, agora um templo.

O outro mito narra a desventura da ninfa Fílira, metamorfoseada em tília, após o nascimento do centauro Quíron, fruto do seu relacionamento com Crono. (O Anexo A detalha ambas as lendas.)

É de se notar que, na Grécia antiga, a tília era considerada uma espécie de árvore sagrada, como lembra Robert-Jacques Thibaud, em seu Dictionnaire de mythologie et de symbologie grecque: "Utilizava-se a tília como planta medicinal, para fabricar o papel ou predizer o futuro" (THIBAUD, 1996, p. 592; trad. minha).

Em sua poesia, Sophia menciona constantemente a Grécia antiga, fato apontado por diversos autores, em artigos e teses acadêmicas ${ }^{4}$. A própria Sophia, na epígrafe do ensaio que dedicou à arte grega, $O$ nu na antiguidade clássica, cuja primeira edição é de 1975, menciona uma afirmação do poeta Murilo Mendes, "Nunca mais escaparemos a esses gregos". Mais adiante, num trecho do ensaio, ela é enfática:

A Grécia recomeça sempre que reconhecemos como verdade, e não como exílio, como alheio, como alienação ou ilusão, o mundo em que estamos. Sempre que buscamos uma relação com a terra em que nada de nós se demita, adie ou transfira. (ANDRESEN, 1992, p. 82)

Esse trecho é fundamental para entendermos o intimismo de Sophia, voltado para o intenso desejo do sujeito no sentido de uma plena e profunda interação de si mesmo com o universo que o cerca. Essa comunhão, porém, torna-se difícil de ser efetivada no mundo de hoje, como demonstra a constatação, direta e sem rodeios, de

\footnotetext{
${ }^{4}$ Citemos, por exemplo, este trecho da dissertação de mestrado de Camila Garcia Scramim, A presença do helenismo de Ricardo Reis e da visão do mundo grego clássico na poesia de Sophia de Mello Breyner Andresen, apresentada ao Centro de Ciências Humanas Letras e Artes da Universidade Estadual de Maringá, em 2006: "A antigüidade clássica é um tema caro à obra de Sophia e representa uma referência de harmonia e perfeição que não se encontra no mundo caótico e confuso [...]. Sendo assim, muitos de seus poemas são celebrações aos modelos gregos de justiça, de perfeição, de beleza, de ordem, e do culto pela arte. Outros são prantos por esses valores perdidos. A cultura grega não só influenciou a poetisa [sic] na temática de suas obras, mas também, na própria composição das mesmas". (SCRAMIN, 2006, p. 73)
} 
"Habitação": "Isso depois foi saqueado", só nos restando lamentar o "trilho/ de Elaboradas percas".

Mas, falávamos de tílias. Através da ligação dessa árvore com a mitologia grega, a última estrofe de "Habitação", por incluir, além da "casa da infância", também o "sussurro das tílias", revela-se carregada de significados. Aproveitando a lenda de Filêmon e Baucis, podemos considerar a tília como uma referência à eternidade, símbolo evidenciado pela propriedade divinatória atribuída à árvore. Além disso, a menção ao "sussurro" implica num comportamento caracteristicamente intimista, como se as "tílias" estivessem se comunicando com o sujeito muito particularmente, quase em segredo, enviando-lhe uma mensagem que só ele, sujeito, poderia entender.

O fato de o verbo "permanece" vir repetido duas vezes, além de implicar na possibilidade de eternidade da própria poesia, leva, também, à idéia da rememoração, exatamente como o "Relembrando" de "Manuel Bandeira". Ora, rememorar, recordar, é uma importante operação do processo intimista, fazendo com que o sujeito, ao se encontrar com suas memórias, se descubra mais perto de si mesmo e de suas emoções.

Ao enfatizar o exercício da memória, a "casa da infância", com a qual se encerra "Habitação", estabelece mais um significativo ponto de contato com "Manuel Bandeira", poema cujo verso "Nos passeados campos da minha juventude" salienta as recordações do tempo da adolescência do sujeito. Assim, tanto "Habitação", como "Manuel Bandeira" realçam a dicotomia entre o tempo da infância, ou da juventude, tempo já passado e, provavelmente mais feliz, e o tempo atual, tempo de desconforto consigo mesmo. O que nos leva a um conceito da historiadora Michele Perrot, relacionando casa, memória e infância, incluído em seu artigo "Maneiras de Morar", no volume 4 da coleção História da vida privada: "Cenário da vida privada e das aprendizagens mais pessoais, tópico das recordações de infância, a casa é o sítio de uma memória fundamental que nosso imaginário habita para sempre” (PERROT, 1992, p. 321).

Com efeito, é a partir da casa que o eu toma conhecimento do mundo que o cerca, pois a casa funciona como um exemplo, em escala microcósmica, daquele macrocosmo maior que o envolve. Ou, nas palavras de Lévinas, ainda citado por Edgard Pereira: "O papel privilegiado da casa não consiste em ser o fim da atividade humana, mas em ser a sua condição e, nesse sentido, o seu começo. $\mathrm{O}$ recolhimento necessário para que a natureza possa ser representada e trabalhada, para que se 
manifeste apenas como mundo, realiza-se como casa" (LÉVINAS, 1988, p. 135, apud PEREIRA, 1999, p. 496).

Mais uma vez recorremos a Bachelard: "a casa é o nosso canto do mundo. Ela é, como se diz freqüentemente, nosso primeiro universo.” (BACHELARD, 1988, p. 112; grifo meu). Mais adiante, ele complementa: “Assim, a casa não vive somente o dia-a-dia[...]. Pelos sonhos, as diversas moradas de nossa vida se interpenetram e guardam os tesouros dos dias antigos. Quando na nova casa, voltam as lembranças das antigas moradias, viajamos até o país da Infância [...]" (BACHELARD, 1988, p. 113).

Bachelard chama a atenção para a estreita ligação entre as lembranças da casa antiga e as memórias vindas do "país da Infância". A respeito da infância, cabe uma citação da professora portuguesa Maria de Fátima Marinho, que a relaciona a "um paraíso perdido, lugar eufórico, por excelência, anterior ao conhecimento do pecado de Adão e Eva" (MARINHO, 1989, p. 82), acrescentando: "A idealização da infância corresponde a uma tendência própria a vários poetas e que se conjuga na figura do sonho, no sentido de desejo e esperança, que transforma a disforia [...] em euforia [...]”. (MARINHO, 1989, p. 83)

Um detalhe: essas considerações têm lugar logo após a professora Marinho mencionar um trecho do poema "Os Astros Nascem", de Reinaldo Ferreira, poeta português que escreveu toda sua obra em Moçambique. O trecho citado trata do quarto e do sofrimento sentido e provocado pelo sujeito, ao nascer:

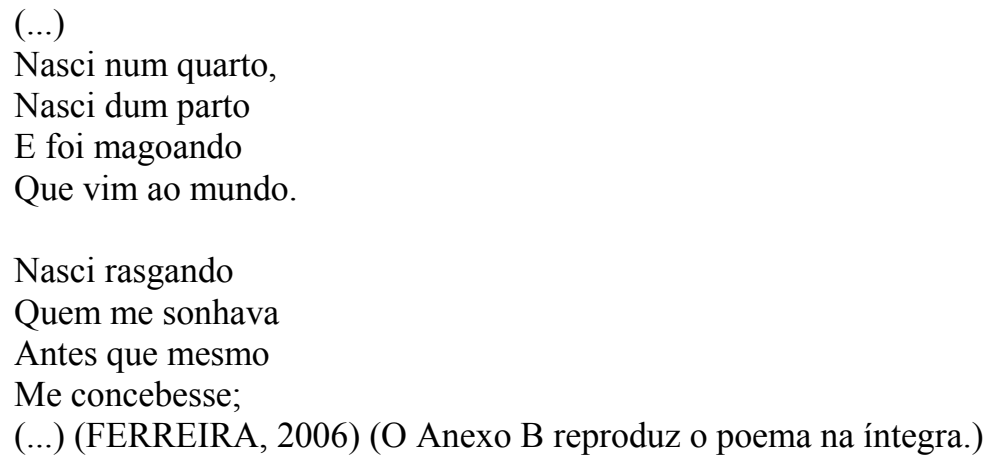

Por falar em "paraíso perdido", um texto de Helena Conceição Langrouva, ao analisar uma série de poemas de Sophia relativos ao mar, refere-se ao "sagrado", não “como uma religião, mas [...] como aliança do homem com a luz cósmica sobre o mar”. Da mesma maneira, podemos perceber, na casa do "princípio", do poema "Habitação", "habitada pelos mortos e por deuses", também um sentimento de eternidade, um símbolo da mesma união sagrada com o cosmos, lembrada agora como 
uma sentida perda, depois que tudo "foi saqueado/ Tudo foi reordenado e dividido". Ou seja, como já comentamos, após o homem haver rompido a primitiva aliança cósmica e sentir, agora, nas palavras da mesma Langrouva, a "ausência do divino na vida actual, [a] degradação do sagrado e [a] invasão da monstruosidade, do monstro como excesso que se expõe ao homem dos nossos dias e o arruína" (LANGROUVA, 2002).

Degradação, com efeito, do homem moderno, impossibilitado de se unir cosmicamente ao universo, pois o próprio mundo encontra-se fragmentado. Afinal, o homem moderno e, também, o homem da segunda metade do século XX, contemporâneo de Sophia, é aquele que, apesar de todos os progressos do conforto e da técnica ${ }^{5}$, parece sempre estar pisando sobre terreno movediço, ao tentar encontrar seu lugar.

Retomando o poema "As Casas", notamos que nele há uma referência ao vento, elemento constantemente utilizado por Sophia. Em "As Casas", o vento aparece como símbolo da imensidão da natureza, como pólo oposto à intimidade da casa onde o sujeito procura abrigo.

Em outras ocasiões, porém, o vento surge como uma possibilidade de libertação para o sujeito, abrindo-lhe uma possibilidade de escape do seu retraimento interior. É o que ocorre, por exemplo, no poema "III", de No tempo dividido, do qual reproduzimos apenas a primeira das duas estrofes:

As paredes são brancas e suam de terror

A sombra devagar sua o meu sangue

Tudo é como eu fechado e interior

Não sei por onde o vento possa entrar

(...) (ANDRESEN, 1991, p. 13)

Nos quatro versos, o estado íntimo do sujeito define-se numa perspectiva bastante amedrontadora, dentro da qual ele se vê exangüe e absolutamente isolado, sem possibilidade de qualquer comunicação com o exterior. $\mathrm{O}$ vento poderia

\footnotetext{
${ }^{5}$ Sophia ironiza tais progressos num poema um tanto humorístico, "Fúrias", incluído em Ilhas. O título refere-se às divindades da antiga Grécia, horríveis na aparência e pertencentes ao mundo inferior, transportadas pela poeta para o mundo de hoje: "Habitam agora a mais íntima humildade/ Do quotidiano. São/ Torneira que se estraga atraso de autocarro/ Sopa que transborda na panela/ Caneta que se perde/ Aspirador que não aspira/ Táxi que não há recibo extraviado/ Empurrão cotovelada espera/ Burocrático desvario". (ANDRESEN, 1999, p.343)
} 
representar uma possibilidade de amenizar tanto "terror" - o termo, apesar de se referir às paredes, elemento limitador do espaço muito utilizado por Sophia, define perfeitamente o medo interior sentido pelo sujeito. Mas o vento acaba não conseguindo chegar até o sujeito, hermeticamente "fechado" em si mesmo.

A respeito do sentimento sofrido por quem se volta exclusivamente para o seu “interior”, há uma reflexão, velha de mais de quatro séculos, do escritor e ensaísta francês Michel Eyquem de Montaigne (1533/1592), que nos aconselha a sempre olhar para fora de nós mesmos, a fim de evitar o "penoso" mergulho em nosso redemoinho íntimo:

A idéia e a prática comuns de olhar para outros lados que não para nós mesmos de muito nos tem valido! Somos para nós mesmos objeto de descontentamento: em nós não vemos senão miséria e vaidade. Para não nos desanimar, a natureza, muito a propósito, nos orientou a visão para o exterior. Avançamos facilmente ao sabor da corrente, mas inverter a nossa marcha contra a corrente, rumo a nós próprios, é um penoso movimento: assim o mar se turva e remoinha quando em refluxo é impelido contra si mesmo. (MONTAIGNE, 2006, grifo meu)

A referência à sofrida imersão no torvelinho íntimo leva-nos novamente a "Manuel Bandeira", pois, na terceira estrofe do poema, o recolhimento/fechamento do sujeito, "No quarto já então pleno de futura/ Saudade", envolve exatamente esse mergulho. Assim, é aqui que Sophia, aprofundando a lente de seu microscópio poético sobre o cenário da casa, chega até o quarto, espaço íntimo por excelência e, não por acaso, definido como "pleno".

O quarto delimita o ambiente mais reservado do sujeito, onde o eu recolhe-se para dentro do seu íntimo, resguardando-se de tudo que o cerca, numa atitude profundamente solitária, que abre espaço para os devaneios da memória. "Sem dúvida", nas palavras do escritor francês Georges Perec, "porque o espaço do quarto funciona, para mim, como uma madeleine de Proust" (PEREC, 1974, p. 34), numa referência aos bolinhos capazes, por si só, de detonar a memória do narrador de Em busca do tempo perdido, de Marcel Proust.

Ora, em "Manuel Bandeira", um dos títulos do poeta brasileiro que o sujeito lê "No quarto" é o "Poema do Beco" (de Estrela da manhã, 1936) que, apesar de curto, apenas um dístico, expressa nitidamente o isolamento sofrido por quem enfrenta, através de uma janela, tudo aquilo que está à sua volta: 
Que importa a paisagem, a glória, a baía, a linha do horizonte?

O que eu vejo é o beco. (BANDEIRA, 1966, p. 228)

Se o "Poema do Beco" pode parecer um tanto pessimista, por focalizar um estado de sofrimento íntimo do sujeito, lembremos que o sujeito de "Manuel Bandeira" lê mais dois poemas de Bandeira, "A Balada das Três Mulheres do Sabonete Araxá" e "Trem de Ferro", todos de Estrela da manhã. Tradicionalmente reconhecidos como duas das melhores peças poéticas do modernismo brasileiro, "A Balada das Três Mulheres do Sabonete Araxá" e "Trem de Ferro", devido a seu tom lúdico, coloquial e, sem dúvida, alegre, ajudam a formar o expressivo contraste dos "sombrios corredores" e das "solenes penumbras" da "casa antiga" de "Manuel Bandeira", com a transparência ("eléctrica" como o amarelo das três mulheres, poderíamos arriscar), do jardim externo à casa. "Estes poemas caminharam comigo e com a brisa/ Nos passeados campos da minha juventude", confessa o sujeito, dando conta da intimidade dele com, digamos, a leveza e o viço do poeta brasileiro - daí a "brisa" e a "minha juventude".

Nesse sentido, é esclarecedor ler "Ouvir o poema", artigo publicado na revista portuguesa Relâmpago, escrito por Eucanaã Ferraz, poeta e professor de Literatura Brasileira na Universidade Federal do Rio de Janeiro. Embora o texto seja centrado em outro poema de Sophia, o "Poema de Helena Lanari", também de Geografia e igualmente incluído, como "Manuel Bandeira", na parte denominada "Brasil ou do Outro Lado do Mar", Eucanaã reporta-se, também, ao poema que homenageia Bandeira:

A imagem do poeta brasileiro ressurge dentro da memória, no tempo e no espaço de uma casa "antiga", de corredores "sombrios" e "solenes penumbras de silêncio". O espanto da avó contrasta com a tranqüilidade da menina que recita os poemas. Não há dúvidas de que há uma aliança entre a juventude da leitora e a juventude dos versos, conforme a última estrofe. [...]

Em meio a sombras vetustas e silenciosas, os versos bandeirianos, sem que isso seja dito explicitamente no poema, funcionam como lâmpadas, estremecimento juvenil, graça, alegria, ar puro. Não são versos embaralhados na lembrança. A memória sabe seus nomes de cor: "[Balada d]As Três Mulheres do Sabonete Araxá", "Trem de ferro", "Poema do beco", poemas de modernidade arrojada, lúdicos, paródicos, dramáticos, repletos de ritmo, claros e sem afetação mas, simultaneamente, refinados ao extremo, construídos como peças de grande força intelectual mas, ao mesmo tempo, plenos de emoção, de erotismo, de revolta. A juventude dos textos resultava, sem dúvida, dessa vitalidade, desse desassombro.

Se o interior da casa parece sintonizar com a avó, a jovem Sophia harmoniza-se com o espaço aberto. (FERRAZ, 2001) 
Em suas observações sobre "Manuel Bandeira", Eucanaã nota o extremo contraste entre o interior, com suas "sombras vetustas e silenciosas", mais ligados à avó, e o "espaço aberto", este em harmonia com a "jovem Sophia", em que pese a confusão entre a poeta e o sujeito poético. E, ao reparar que "a memória sabe [os nomes dos poemas de Bandeira] de cor”, Eucanaã deixa implícita a profunda relação entre os poemas de Bandeira e as lembranças íntimas do sujeito.

O "espaço aberto", escreve ainda Eucanaã, "apresenta um [lugar] e um tempo luminosos, arejados, nos quais reina uma cerejeira", embora, outra vez, ele personalize a "menina Sophia" como o sujeito do poema:

Não por acaso, os bancos têm a tinta ainda fresca, porque tudo é recente, verdejante, viçoso. As mulheres do poema bandeiriano surgem sem as aspas que lhes apontavam a condição literária. Agora, as três mulheres estão vivas, como a árvore; são "visíveis", como se recortadas pela tesoura que ficou "esquecida nos ramos da cerejeira". No tempo e no espaço da juventude, misturam-se, portanto, o real, o fantasioso, o imaginário, num quadro em que a menina Sophia e a poesia de Manuel Bandeira se irmanam, respiram a mesma ternura, igualam-se na saúde, no vigor e na liberdade. (FERRAZ, 2001)

Enfim, para finalizar nossa análise de "Manuel Bandeira", assinalamos uma das particularidades estilísticas próprias de Sophia: o "espanto" vem repetido duas vezes (da mesma forma como o "silêncio", ou a menção às "três mulheres do sabonete Araxá"), criando assim uma moldura adicional para o assombro causado pela imagem das três mulheres, imagem essa, na verdade, irreal, mas, ao mesmo tempo, extremamente "visível" (adjetivo do próprio poema), ou viva, como bem notou Eucanãa.

A respeito do espanto, vejamos o que acontece, no texto poético de Sophia “As Grutas", de Livro sexto:

O esplendor poisava solene sobre o mar. E - entre as duas pedras erguidas numa relação tão justa que é talvez ali o lugar da Balança onde o equilíbrio do homem com as coisas é medido - quase me cega a perfeição como um sol olhando de frente. Mas logo as águas verdes em sua transparência me diluem e eu mergulho tocando o silêncio azul e rápido dos peixes. Porém a beleza não é só solene mas também inumerável. De forma em forma vejo o mundo nascer e ser 
criado. Um grande rascasso vermelho passa em frente a mim que nunca antes o imaginara. Limpa, a luz recorta promontórios e rochedos. É tudo igual a um sonho extremamente lúcido e acordado. Sem dúvida um novo mundo nos pede novas palavras, porém é tão grande o silêncio e tão clara a transparência que eu muda encosto a minha cara na superfície das águas lisas como um chão.

As imagens atravessam os meus olhos e caminham para além de mim. Talvez eu vá ficando igual à almadilha da qual os pescadores dizem ser apenas água.

Estarão as coisas deslumbradas de ser elas? Quem me trouxe finalmente a este lugar? Ressoa a vaga no interior da gruta rouca e a maré retirando deixou redondo e doirado o quarto de areia e pedra. No centro da manhã, no centro do círculo do ar e do mar, no alto do penedo, no alto da coluna está poisada a rola branca do mar. Desertas surgem as pequenas praias.

Um fio invisível de deslumbrado espanto me guia de gruta em gruta. Eis o mar e a luz vistos por dentro. Terror de penetração na habitação secreta da beleza, terror de ver o que nem em sonhos eu ousara ver, terror de olhar de frente as imagens mais interiores a mim do que o meu próprio pensamento. Deslizam os meus ombros cercados de água e plantas roxas. Atravesso gargantas de pedra e a arquitectura do labirinto paira roída sobre o verde. Colunas de sombra e luz suportam céu e terra. As anémonas rodeiam a grande sala de água onde os meus dedos tocam a areia rosada do fundo. E abro bem os olhos no silêncio líquido e verde onde rápidos, rápidos fogem de mim os peixes. Arcos e rosáceas suportam e desenham a claridade dos espaços matutinos. Os palácios do rei do mar escorrem luz e água. Esta manhã é igual ao princípio do mundo e aqui eu venho ver o que jamais se viu.

O meu olhar tornou-se liso com um vidro. Sirvo para que as coisas se vejam.

E eis que entro na gruta mais interior e mais cavada. Sombrias e azuis são águas e paredes. Eu quereria poisar como uma rosa sobre o mar o meu amor neste silêncio. Quereria que o contivesse para sempre 
o círculo de espanto e de medusas. Aqui um líquido sol fosforescente e verde irrompe dos abismos e surge em suas portas.

Mas já no mar exterior a luz rodeia a Balança. A linha das águas é lisa e limpa como um vidro. O azul recorta os promontórios aureolados de glória matinal. Tudo está vestido de solenidade e de nudez. Ali eu quereria chorar de gratidão com a cara encostada contra as pedras. (ANDRESEN, 1991, p. 175)

É fácil perceber que a"gruta" constitui sinônimo perfeito para "quarto", detalhe bem explicitado no terceiro parágrafo: "Ressoa a vaga no interior da gruta rouca e a maré retirando deixou redondo e doirado o quarto de areia e pedra”. Se, em "Manuel Bandeira", a repetição do "silêncio" serve para reiterar o estado de introspecção do sujeito, já em "As Grutas", a recorrência do mesmo "silêncio", em quatro ocasiões $\left(6^{\mathrm{a}}\right.$ e $12^{\mathrm{a}}$ linhas do $1^{\mathrm{o}}$ parágrafo, $10^{\mathrm{a}}$ linha do $4^{\mathrm{o}}$ parágrafo e $3^{\mathrm{a}}$ linha do $6^{\circ}$ parágrafo), aponta para um desejo de "perfeição" e "beleza", ao lado da instauração de um "novo mundo", em oposição ao mundo real, destroçado e imperfeito, do qual, para fugir, o eu mergulha no universo submarino - mergulho que, como veremos, também metaforiza a imersão do sujeito poético para dentro de seu próprio íntimo.

Um texto como "Grutas" merece do leitor toda a atenção, um texto para ser lido com calma. Sophia escolheu as primeiras palavras como se estivesse iniciando um ritual: "O esplendor poisava solene sobre o mar". Assim, começamos a lê-lo como se nos preparássemos para uma cerimônia magnífica, "solene", para repetirmos o qualificativo utilizado pela poeta. Logo a seguir a constatação de que o "equilíbrio do homem com as coisas" refere-se a uma "relação tão justa" cuja "perfeição" cega o sujeito como um "sol olhando de frente", em mais uma referência à necessidade da integração cósmica entre o homem e a natureza.

O início do quarto parágrafo, depois de mencionar o "deslumbrado espanto" que "guia" o sujeito de "gruta em gruta", vai se referir ao "terror", este repetido três vezes. Na terceira, o "terror" refere-se ao ato de "olhar de frente as imagens mais interiores a mim do que o meu próprio pensamento" e podemos ler, aqui, a idéia do receio que o sujeito sente de mergulhar em seu íntimo. A primeira e a última frase do parágrafo, ao se reportarem ao "fio invisivel de deslumbrado espanto" (primeira frase, grifo meu) e ao fato de que "aqui eu venho ver o que jamais se viu" (última, idem), estabelecem um nítido contraste entre ver e não ver, deixando claro o quão importante 
é, para o sujeito poético de Sophia, a percepção do mundo e dos elementos que o compõem.

Nesse sentido de união total com o mundo, recorremos a palavras da própria Sophia, numa entrevista de 1991, para o periódico português Jornal de Letras. A entrevista foi conduzida por, José Carlos de Vasconcelos que, a certa altura observa à poeta que "na sua poesia [existe] uma grande ligação directa com as coisas, os objectos, uma certa luz, uma captação do essencial” (VASCONCELOS, 1991, p. 9). Ao que, obtém de Sophia a seguinte resposta:

Penso que nós procuramos sobretudo o que nos dá felicidade, não acha? Procuramos o que nos cria uma certa libertação intima que é necessária à felicidade. Procuramos o ser um com o universo. (VASCONCELOS, 1991, p. 9, grifos meus)

Ao mergulhar em seu próprio interior - tarefa que não é fácil, daí o "terror" o sujeito de “As Grutas" também está mais próximo dessa comunhão, desse esplendor, desse deslumbramento, para utilizar o vocabulário do poema. Percebemos que Sophia recorre a expressões ligadas à pureza, à inocência, para descrever o estado de um mundo não contaminado, direcionando os anseios do sujeito à busca de um renascimento, daí a insistência no momento da manhã, como símbolo do princípio do dia e, por extensão, do "princípio do mundo": "Esta manhã é igual ao princípio do mundo (...)".

Note-se, também, os "arcos e rosáceas" que "desenham a claridade dos espaços matutinos", numa evidente referência à arquitetura das catedrais góticas, o que empresta ao texto um tom sacralizante. Na sentença seguinte, aparecem os "palácios", construções volta e meia citadas pela poeta, como no já mencionado poema "Habitação", ou em "A Escrita", de Ilhas, que traz o "Palácio Mocenigo onde viveu sozinho /Lord Byron (ANDRESEN, 1999, p.38), referência ao pallazzo do século XVI localizado em Veneza, no qual Byron morou ("sozinho", portanto mais próximo de si mesmo) algum tempo. Os "palácios" podem, outrossim, remeter a "O Palácio da Ventura", um dos mais famosos sonetos de Antero de Quental, esse que foi, como já frisamos, um dos precursores da poesia intimista portuguesa, no século XIX. 
O "palácio" de Antero, aliás, pertenceu à memória afetiva da própria Sophia, como ela confessou, na mesma entrevista ao Jornal de Letras que acabamos de citar:

Quando eu era pequena e não sabia ler nem escrever, ouvia um soneto do Camões ou do Antero e dava-me a impressão de um palácio extraordinário. $\mathrm{O}$ de Camões era de vidro, ou de cristal, brilhante, o de Antero era mais sombrio e mais floresta. (VASCONCELOS, 1991, p. 9; grifo do autor)

Incluímos, a seguir, "O Palácio da Ventura", aproveitando para observar que os dois vocábulos que abrem o último verso, "Silêncio e escuridão", identificam-se com dois dos elementos mais utilizados por Sophia nos poemas analisados neste capítulo, o próprio "silêncio" e as "penumbras":

Sonho que sou um cavaleiro andante.

Por desertos, por sóis, por noite escura,

Paladino do amor, busca anelante

O palácio encantado da Ventura!

Mas já desmaio, exausto e vacilante, Quebrada a espada já, rota a armadura... E eis que súbito o avisto, fulgurante $\mathrm{Na}$ sua pompa e aérea formosura!

Com grandes golpes bato à porta e brado:

Eu sou o Vagabundo, o Deserdado...

Abri-vos, portas d'ouro, ante meus ais!

Abrem-se as portas d'ouro, com fragor...

Mas dentro encontro só, cheio de dor,

Silêncio e escuridão - e nada mais! (QUENTAL, 1972, p.80)

Estávamos em "As Grutas". Nesse texto, o "quarto", "de areia e pedra", assume o esplendor à sua volta, "redondo e doirado". Tudo se relaciona à "perfeição" das "coisas deslumbradas de ser elas", à exatidão traduzida pelo "centro", seja o "centro da manhã" (a parte inicial e mais luminosa do dia), ou o "centro do círculo", círculo que é uma figura exata, completa nela mesma, "o mais importante e difundido símbolo geométrico" (BIEDERMANN, 1993, p. 96). Ou, segundo Juan-Eduardo Cirlot, "símbolo do estar fechado em si mesmo, perfeito, eterno" (CIRLOT, 1984, p. 138 , grifo meu). 
O formato do círculo, ao repercutir no "redondo" do "quarto de areia e pedra", implica, portanto, no desenho de algo totalmente fechado em seus limites, adequada metáfora para o próprio quarto. Lembremos que o círculo representa, também, o infinito, ou seja, o eterno retorno, o eterno recomeço - o que, de certa forma evoca as operações da memória que o quarto propicia.

A perfeição continua "no alto da coluna", onde, em primeiro lugar, podemos ler uma referência à limpeza arquitetônica dos templos da Grécia clássica. Além disso, encontramos no Dicionário de símbolos, de Chevalier e Gheerbrant, a observação de que as colunas "simbolizam a solidez de um edifício, quer seja ele arquitetural, quer seja social ou pessoal" (CHEVALIER \& GHEERBRANT, 1999, p. 265). Então, a "perfeição" mencionada por Sophia estaria se referindo ao reconhecimento, por parte do sujeito, de sua própria inteireza e de seu deslumbramento, frente às maravilhas do universo.

A poeta diz mais: "no alto da coluna está poisada a rola branca do mar". Se pensarmos na Chevalier e Gheerbrant "rola branca" como a pomba branca que é tradicionalmente considerada símbolo da paz, poderemos visualizar o mar como referência de repouso, tranqüilidade e sossego, estados importantes para um sujeito preocupado em encontrar sua completa comunhão com o cosmos.

Seguindo com "As Grutas", encontramos as "Colunas de sombra e luz" que "suportam céu e terra". Tingidas pela luminosidade própria de Sophia, que combina os dois contrários "sombra e luz" numa única imagem, as "colunas" estariam unindo o "céu" à "terra", o que nos faz, mais uma vez, recorrer a Chevalier e Gheerbrant: “Árvore da vida, árvore cósmica, árvore dos mundos, a coluna liga o alto e o baixo, o humano e o divino" (CHEVALIER \& GHEERBRANT, 1999, p. 266). Ou seja, podemos ler, nas entrelinhas de "As Grutas", a fascinação do sujeito ao tentar, irmanado aos prodígios da natureza, suplantar a sua essência humana, almejando alcançar a imortalidade divina.

Enfim, em meio a tantas maravilhas, nada como tomar de empréstimos as palavras de mais um poeta, Fabrício Carpinejar, que se referiu desta maneira à poesia de Sophia, num artigo escrito por ocasião do falecimento dela: "Suas descobertas são puras, maravilhamentos miúdos entre o visível e o invisível" (CARPINEJAR, 2004).

Já nos referimos a esse contraste entre o visível e o invisível, mas vale enfatizar que, em "As Grutas", o sentido da visão é constantemente aguçado, através de verbos e substantivos que lhe são diretamente relacionados, como podemos perceber nos 
exemplos a seguir, além daqueles que já apontamos (grifos meus): “quase me cega a perfeição como um sol olhando de frente"; "as águas verdes em sua transparência"; "De forma em forma vejo o mundo nascer e ser criado"; "a luz recorta promontórios e rochedos"; "um sonho extremamente lúcido e acordado"; "tão clara a transparência"; "as imagens atravessam os meus olhos"; "o mar e a luz vistos por dentro"; "terror de ver o que nem em sonhos eu ousara ver, terror de olhar de frente as imagens mais interiores a mim"; "abro bem os olhos no silêncio líquido e verde"; "a claridade dos espaços matutinos"; "O meu olhar tornou-se liso com um vidro. Sirvo para que as coisas se vejam".

Justamente por causa do apelo à evidência de tudo o que há para ver, adquire ênfase especial a única frase que descreve o sujeito olhando, não o panorama espetacular que se desenrola ao seu redor, mas aquilo que ele guarda dentro de si: "terror de ver o que nem em sonhos eu ousara ver, terror de olhar de frente as imagens mais interiores a mim". Como assinalamos, a insistência no "terror", realça o medo íntimo do sujeito que, submerso num espetáculo (o fundo do mar) de beleza e perfeição, percebe a sua incapacidade de aproveitar o que presencia, algo assim como o homem contemporâneo, soterrado pelas mil e uma descobertas do progresso e da técnica, aparentemente brilhantes e perfeitas, mas insuficientes para garantir sua felicidade.

Pois é esse desejo de se comungar com o universo, tanto do sujeito poético, quanto do homem, às vezes tão difícil de realizar, que leva ao "espanto", ecoado por duas vezes no texto "As Grutas" (aliás, também em "Manuel Bandeira”), a primeira como um "deslumbrado espanto" ( $1^{\mathrm{a}}$. linha do $4^{\mathrm{o}}$ parágrafo), a segunda no "círculo de espanto e de medusas" ( $4^{\mathrm{a}}$. linha do $6^{\circ}$ parágrafo).

A respeito do círculo, já falamos. Quanto às medusas, seres marinhos amiúde citados por Sophia, tratam-se de animais celenterados, muitas vezes confundidos com plantas por causa de seu aspecto, cuja origem é narrada pela mitologia grega. Junto com os corais e anêmonas do mar, teriam nascido das gotas do sangue da Górgona Medusa, quando esta teve sua horripilante cabeça, com os cabelos formados por serpentes, decapitada por Perseu ${ }^{6}$. As medusas são bastante recorrentes na poesia de Sophia e teremos ocasião para voltar a falar sobre elas.

\footnotetext{
${ }^{6}$ Ver o Anexo C.
} 
Antes de terminar a análise de "As Grutas", voltamos a citar Langrouva, que nota, a propósito de Sophia utilizar o adjetivo "rouca" para qualificar a "gruta" (terceiro parágrafo do texto), a possibilidade de a gruta constituir uma metáfora para o próprio interior do eu poético:

O adjectivo "rouco", relacionado com o som cavo, repete-se. [em "As Grutas" e também no poema "Gruta do Leão"] assim como a cor "roxa", o escuro e colorido da gruta, a sua essência de "puro interior", a presença simultânea da sombra e da luz - "e brilho" -, enfim uma acumulação de metáforas do mais recôndito da alma do sujeito lírico. (LANGROUVA, 2002)

“Gruta do Leão", de Livro sexto, reproduzido a seguir, é um poema curto, com uma estrofe, no qual a "gruta" é "Feita de puro interior", assemelhando-se a um quarto:

Para além da terra pobre e desflorida

Mostra-me o mar a gruta roxa e rouca

Feita de puro interior

E povoada

De cava ressonância e sombra e brilho (ANDRESEN, 1991, p. 100)

Notamos, no poema, a importância que o sujeito encontra na "gruta roxa e rouca", colocada em oposição à "terra", esta caracterizada por dois adjetivos de conotação negativa, "pobre e desflorida". A "gruta", ao ser caracterizada como "de puro interior" (grifo meu), parece espelhar o próprio íntimo do sujeito. E, por ser "povoada/ De cava ressonância e sombra", apresenta condições favoráveis ao exercício de introspecção do sujeito, devido à "ressonância" e à "sombra". Numa direção contrária, repetindo a característica tão típica de Sophia de estar sempre aproximando os opostos, há também o "brilho", capaz de iluminar o mesmo sujeito, no sentido deste encontrar uma saída para suas dúvidas íntimas.

A gruta metaforizando a "alma do sujeito", como apontou Langrouva, talvez seja mais nítida em outro poema de Sophia, este de Geografia e intitulado "Manhã", no qual o sujeito reconhece possuir um "coração de gruta":

Na manhã recta e branca do terraço

Em vão busquei meu pranto e minha sombra 
O perfume do orégão habita rente ao muro

Conivente da seda e da serpente

No meio-dia da praia o sol dá-me

Pupilas de água mãos de areia pura

A luz me liga ao mar como a meu rosto

Nem a linha das águas me divide

Mergulho até meu coração de gruta

Rouco de silêncio e roxa treva

O promontório sagra a claridade

A luz deserta e limpa me reúne (ANDRESEN, 1999, p. 12)

Aqui, a primeira singularidade a notar são os asteriscos, pois Sophia quase nunca recorreu a recursos visuais para seus poemas. Curiosamente, remetem a velhos textos impressos, pois constituem recursos gráficos pouco utilizados atualmente, fazendo-nos recordar os antigos almanaques, ou folhinhas, que costumavam trazer várias máximas e provérbios populares, separados entre si por asteriscos.

Cada estrofe funciona de maneira isolada, algumas de beleza muito particular, como a que se refere ao "perfume do orégão", à "seda" e à "serpente", três fortes vetores simbólicos; ou a que unifica sujeito e "mar" num esplendor de "luz" tão intenso, que nem "a linha das águas me divide".

Graças, ainda, à sugestão dos almanaques, poderíamos aproveitar cada estrofe como pílulas de sabedoria, pois elas quase que representam conselhos para que tentássemos nos comportar como o eu-poeta do poema, nos encontrando, assim, mais próximos tanto da natureza, como da epifania constantemente defendida por Sophia.

É de se notar que o "meu coração de gruta" que, além de estar indubitavelmente ligado ao sujeito, pela utilização do possessivo "meu", é também caracterizado pelo "silêncio", tema deste capítulo. Na mesma estrofe, os adjetivos "rouco" e "roxa", remetem ao poema "Gruta do Leão". 
Mas é com o texto "As Grutas" que o poema "Manhã" apresenta um maior grau de afinidade. O "meio-dia" da terceira estrofe, momento de maior luz de todo o dia, ecoa na passagem referente ao "centro da manhã" de "As Grutas", enquanto a intensa relação entre a luz, o mar e o sujeito, em versos de "Manhã", como "A luz me liga ao mar como a meu rosto", ou "A luz deserta e limpa me reúne", remetem à passagem “Mas logo as águas verdes em sua transparência me diluem”, do primeiro texto.

Mesmo que não tenhamos a presença do quarto em "Manhã", esse poema traz o cenário do "terraço", elemento também ligado à poética intimista, pois significa um espaço de intermediação entre o interior da casa e o seu exterior. Posto no "terraço", é como se sujeito estivesse no limiar de si mesmo, confrontando o "pranto" e a "sombra" de seu interior, com tudo o que se encontra lá fora, o "meio-dia", o "sol", a “claridade". De se notar, também, a função do "terraço" como ponto de observação, a partir do qual o sujeito tem melhores condições de ver o que se passa.

Enfim, assim como “As Grutas", também "Manhã” termina em clima de celebração, inclusive sagrada: "O promontório sagra a claridade/ A luz deserta e limpa me reúne". Notamos que o sujeito insiste na expressão "me reúne", como se referisse à própria comunhão com a natureza do seu eu anteriormente fragmentado.

"Manhã” repete a menção ao "promontório", como em "As Grutas”, nesse texto também relacionado a uma possível união sagrada entre o sujeito e a natureza: "O azul recorta os promontórios aureolados de glória matinal. (...) Ali eu quereria chorar de gratidão com a cara encostada contra as pedras". Mas a dupla ocorrência do mesmo acidente geográfico não constitui mera coincidência (nada em Sophia é coincidência), pois Langrouva refere-se à "topologia do promontório como lugar de pausa para oração, como acontece com freqüência ao longo dos litorais portugueses e mediterrânicos" (LANGROUVA, 2002).

Temos, ainda, duas derradeiras observações a respeito de "As Grutas". A primeira, sobre as "coisas", repetidas/enfatizadas três vezes no texto, indicando, mais uma vez, o valor que Sophia confere à percepção acurada do mundo real. A segunda, sobre a palavra "almadilha" (segundo parágrafo), aparentemente criada por Sophia, pois não consta dos dicionários (ver Anexo D).

Passemos a um outro poema de Sophia, incluído em Livro sexto. Trata-se de "Musa", no qual o "quarto" ocupa uma posição de destaque:

Musa ensina-me o canto 
Venerável e antigo

$\mathrm{O}$ canto para todos

Por todos entendido

Musa ensina-me o canto

O justo irmão das coisas

Incendiador da noite

E na tarde secreto

Musa ensina-me o canto

Em que eu mesma regresso

Sem demora e sem pressa

Tornada planta ou pedra

Ou tornada parede

Da casa primitiva

Ou tornada o murmúrio

Do mar que a cercava

(Eu me lembro do chão

De madeira lavada

E do seu perfume

Que atravessava)

Musa ensina-me o canto

Onde o mar respira

Coberto de brilhos

Musa ensina-me o canto

Da janela quadrada

E do quarto branco

Que eu possa dizer como

A tarde ali tocava

$\mathrm{Na}$ mesa e na porta 
No espelho e no corpo

E como os rodeava

Pois o tempo me corta

O tempo me divide

O tempo me atravessa

E me separa viva

Do chão e da parede

Da casa primitiva

Musa ensina-me o canto

Venerável e antigo

Para prender o brilho

Dessa manhã polida

Que poisava na duna

Docemente os seus dedos

E caiava as paredes

Da casa limpa e branca

Musa ensina-me o canto

Que me corta a garganta (ANDRESEN, 1991, p. 102)

Há muito a ser analisado no poema, sob a perspectiva do intimismo. Em primeiro lugar, assinalemos, que ao lê-lo, fica difícil não lembrar a primeira parte daquela afirmação de Fiama Hasse Pais Brandão citada na Introdução desta dissertação, "Eis a aprendizagem fundamental: chamar $\mathrm{Eu}$ às coisas [...]" (BRANDÃO, 1988, p. 80; grifo meu). Enquanto Fiama fala em “aprendizagem”, o eu poético de "Musa" está, repetida e constantemente, pedindo à sua musa "ensina-me". Além disso, o pedido refere-se ao ensino de um canto não só "justo irmão das coisas" (podemos perceber, nessa expressão, a expressão de um carinho fraterno, portanto íntimo), mas, também, capaz de consubstanciar o próprio sujeito em "planta ou pedra", ou seja, comungar o eu com o mundo concreto, aqui representado pelos reinos vegetal e mineral. 
Bem a propósito, seria interessante mencionar, ainda que de passagem, a importância da "pedra" na temática particular de Fiama ${ }^{10}$. Citamos um dos poemas dessa poeta, incluído no livro As fábulas, de 2002, que compara a pedra ao eu poético. Aliás, o título é "Da pedra":

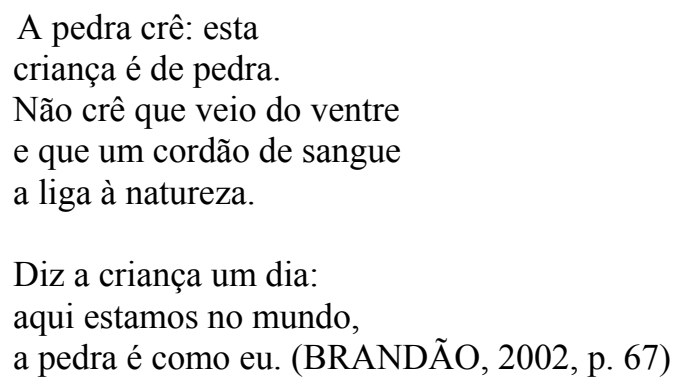

Voltemos à Sophia e a "Musa". Além da casa, nesse poema definida como "primitiva", temos o quarto, na verdade, o "quarto branco", identificado pela cor branca que, como veremos, é uma das mais freqüentes em Sophia. O poema evidencia, ainda, aqueles fatores que, dentro da casa ou do quarto, limitam ou abrem o espaço vivido pelo sujeito, como a "parede", a "janela", a "porta" e o "espelho".

Quanto a isso, vale incluir um comentário sobre "Musa", feito por Ana Helena Cizotto Belline em sua dissertação de mestrado, Da solidão à solidariedade: uma leitura da obra poética de Sophia de Mello Breyner Andresen:

A presença do quarto, e dentro dele a da janela, e [...] a do espelho, leva-nos à compreensão de um movimento [...] de um fechamento progressivo do espaço, que, passando da casa ao quarto, abre-se no entanto em duas linhas diversas: a janela como abertura para o mundo exterior, e o espelho como um mergulho na profundidade do eu. (BELLINE, 1985, p. 71)

Sobre a "janela" e ao "espelho", teremos oportunidade, no decorrer deste trabalho, de abordar esses elementos em maior profundidade. "Musa" também menciona a "noite", referência temporal importante para o intimismo, pois o escuro e o isolamento propiciam as operações de introspecção do sujeito; estudaremos, a seu devido tempo, uma série de poemas de Sophia que enfocam a noite. O mesmo será feito em relação ao "mar", paisagem exterior à casa e de especial predileção por parte de Sophia, cuja vastidão lembra ao sujeito a pequenez de sua natureza humana, comparada à imensidão da natureza.

\footnotetext{
${ }^{10}$ Consultar a respeito, por exemplo, o artigo do professor Jorge Fernandes da Silveira, "Da idade da pedra - Fiama poeta", mencionado nas Referências Bibliográficas.
} 
Tudo isso, repetimos, será focalizado em maior detalhe, mais à frente, quando estudarmos outros poemas que trazem os mesmos elementos. Gostaríamos, agora, de assinalar, em "Musa", alguns outros aspectos. Como o fato de, a partir do título, o poema identificar-se com a própria história da poesia portuguesa, lembrando, sem dúvida, a "musa" de Camões, como em "Detém um pouco, Musa, o largo pranto" (CAMÕES, 1981, p. 91), verso cujo "pranto" rima com o "canto" do poema de Sophia, ou principalmente, "Cesse tudo o que a Musa antiga canta", famoso verso da terceira estrofe do Canto I de "Os Lusíadas" (CAMÕES, 1996, p. 61). É nesse sentido que Sophia utiliza os adjetivos "Venerável e antigo", para "o canto" ensinado pela "Musa".

Outro ponto que observamos em "Musa" é a maneira como o poema apresenta certos itens caros à poética intimista, que se reportam a poemas que já analisamos. É o caso, por exemplo, da menção ao "brilho/ Dessa manhã polida/ Que poisava na duna" que repercute, em termos da claridade de "manhã" e do cenário litorâneo, com passagens do texto "As Grutas". Já a "casa primitiva", imagem reiterada na quarta e na sexta estrofe, que, dentro do próprio poema, apresenta um certo eco com "o canto/ Venerável e antigo" da "Musa", também lembra a "casa antiga" de "Manuel Bandeira", ou a "antiga/ Casa bela e grave" de "Habitação".

$\mathrm{Na}$ verdade, à medida que lemos, com atenção, toda a obra poética de Sophia, percebemos o quanto certos vocábulos e determinadas construções são recorrentes, repetidas quase que palavra por palavra, em poemas diferentes. Ou, como constata Vivian Steinberg, em uma passagem inspirada de sua dissertação de mestrado, No Poema: um paradigma da tessitura poética de Sophia de Mello Breyner Andresen: "Há uma forma que inspira os poemas de Sophia, parece que eles se enrodilham em espiral. Um poema surge de dentro do outro" (STEINBERG, 2006, p. 11).

Assim, dois temas que já analisamos, o da casa e o da penumbra, estão igualmente presentes em "Casas", poema de Ilhas que incluímos a seguir. Dedicado por Sophia à poeta Luiza Neto Jorge "Casas" descreve uma "penumbra sequiosa" envolvendo o quarto, na verdade quartos, "quarto após quarto":

Casas - casas roucas

Atentos muros - umbrais medidos e solenes

Quarto após quarto penumbra sequiosa

Tectos lentos 
Como no espelho afloram

Lagos e magia: caminho

Submerso do possível

A paixão habita seu jogo mais secreto

Sua trágica e precisa

Perfeição (ANDRESEN, 1999, p. 340)

A leitura de "Casas" revela um ritmo, digamos, quebrado, no qual as palavras parecem vir aos saltos, efeito favorecido pelos travessões que impõem uma pausa forçada, já nos dois primeiros versos. Note-se o termo escolhido para adjetivar as casas, "roucas" (outra vez, uma antropomorfização), implicando numa dificuldade do ato de falar. Interessante observar que a dedicatória é, não por acaso, dirigida a Luiza (que Sophia grafa como Luísa) Neto Jorge, poeta radicalmente diferente de Sophia quanto à construção de seus poemas - daí, talvez, o ritmo fragmentado de Casas. Por outro lado, ao voltar-se para uma poeta mais jovem, atuante no momento de elaboração do poema (a primeira edição de Ilhas é de 1987), Sophia demonstra também estar interessada na obra de poetas de uma geração posterior à sua e então vivos (Luiza morreu em 1989), mesmo que a maioria dos outros poetas, citados por ela em sua obra poética, seja constituída por poetas já mortos e de certa forma canonizados, como o inglês Lord Byron, os portugueses Camões, Cesário Verde e Fernando Pessoa, alcem dos brasileiros Manuel Bandeira, Cecília Meireles, da qual falaremos logo adiante, ou Murilo Mendes.

Se "Casas" enumera vários dos itens caros à elaboração da poesia intimista, como as próprias "casas", os "muros", os "umbrais" (sinônimos de portas), o "espelho", ou os "tectos" (que podemos ler como um componente arquitetônico a comprimir o sujeito), torna-se bastante significativo recordar que uma série escrita por Luiza chama-se exatamente "As Casas" (de Os sítios sitiados, 1973), contando um total de quinze poemas, incluindo o último, intitulado "Posfácio às Casas".

Fica irresistível a tentação de incluir aqui, ao menos, um dos poemas de Luiza dessa série. Escolhemos o primeiro, identificado apenas pelo numeral "I", não só por razões de gosto pessoal, mas, também, por incluir alguns importantes referentes intimistas. Em especial, o "silêncio", objeto deste capítulo e presente na última estrofe: 
As casas vieram de noite

De manhã são casas

À noite estendem os braços para o alto

Fumegam vão partir

Fecham os olhos

percorrem grandes distâncias

como nuvens ou navios

As casas fluem de noite

sob a maré dos rios

São altamente mais dóceis

que as crianças

Dentro do estuque se fecham

Pensativas

Tentam falar bem claro

no silêncio

com sua voz de telhas inclinadas (JORGE, 1993, p. 98)

É bem possível que, em seu poema, Sophia, ao mencionar às "casas roucas", esteja se referindo ao "falar" das "casas" que Luiza preferiu expressar como "voz de telhas inclinadas" (tanto Sophia como Luiza constroem, cada uma à sua maneira, imagens poéticas de grande intensidade). Observamos também que, ao escolher termos como "nuvens", "navios" ou "noite" (três aliterações em "n”), Luiza privilegia um léxico muito ao gosto de Sophia, além do fato de "navio" ser uma das metáforas mais utilizadas para "casa". Não podemos, também, deixar de assinalar a antropomofização que Luiza faz das casas, adotando outro recurso comum em Sophia.

Mas o parêntesis dedicado à Luiza iniciou-se devido a uma das referências de Sophia à penumbra, em seus poemas. Ora, em "Arte Poética", do décimo quarto e último livro (sem contar as antologias) de poesia de Sophia, O Búzio de Cós e outros poemas, de 1997, voltamos a encontrar a penumbra, caracterizando o interior do quarto:

A dicção não implica estar alegre ou triste

Mas dar minha voz à veemência das coisas

E fazer do mundo exterior substância da minha mente

Como quem devora o coração do leão

Olha fita escuta

Atenta para a caçada no quarto penumbroso (SOPHIA, 2004) 
Para o leitor brasileiro mais informado sobre poesia, é difícil não associar o primeiro verso deste poema a "Motivo", do livro Viagem, de 1939, talvez o mais popular poema de Cecília Meireles, e cuja primeira estrofe reproduzimos a seguir:

Eu canto porque o instante existe e a minha vida está completa.

Não sou alegre nem sou triste: sou poeta.

(...) (MEIRELES, 1965, p. 7)

Sabe-se que Sophia foi, ela própria, leitora atenta de Cecília, tendo, inclusive, publicado, em 1956, o ensaio A poesia de Cecília Meireles, no qual analisa três livros da chamada fase de maturidade da poeta brasileira, Viagem, Vaga música e Mar absoluto. Por ocasião da morte de Cecília, Sophia dedicou-lhe um poema, "Na morte de Cecília Meireles", incluído em Geografia. Enfim, Sophia não dialoga com Cecília de forma gratuita, pois a poeta brasileira também se preocupou em caracterizar o intimismo em sua obra? ${ }^{7}$.

Ainda quanto ao poema "Arte Poética", notamos a caracterização do quarto, como "penumbroso", que de certa forma se reporta ao que já vimos em "Manuel Bandeira" e em "Casas". Além disso, o sujeito de "Arte Poética" manifesta um veemente desejo de se comunicar com o lá fora, "fazer do mundo exterior substância da minha mente", talvez num ato de suprema coragem (afinal, no quarto estão as penumbras a serem transpostas), coragem que poderíamos ver simbolizada pela façanha de devorar "o coração do leão". Mas não se trata de empresa fácil; daí a necessidade de atenção, numa atitude de olhar, fitar e escutar, como numa "caçada".

$\mathrm{Na}$ verdade, os três vocábulos escolhidos por Sophia, "coração", "leão" e caçada", envolvem rica simbologia. Comecemos pelo leão, "poderoso, soberano, símbolo solar e luminoso ao extremo", considerado como o "rei dos animais", nas palavras de Chevalier e Gheerbrant (CHEVALIER \& GHEERBRANT, 1999, p. 538, grifo dos autores). Também Biedermann cita o mesmo epíteto do leão, “ freqüentemente [...] mencionado na heráldica e nas fábulas como o rei dos animais. (BIEDERMANN, 1993, p. 210, grifo do autor).

\footnotetext{
${ }^{7}$ A respeito de relacionamentos possíveis entre a poesia de Sophia e a de Cecília Meirelles, vale consultar a tese de doutoramento de Jussara Neves Rezende, A simbolização nas imagens poéticas de Cecília Meireles e Sophia de Mello Breyner Andresen: tempo e espaço, apresentada em 2006 à Faculdade de Filosofia Letras e Ciências Humanas da USP.
} 
Enquanto a simbologia relativa ao leão coloca-o no topo do reino animal, ao analisarmos os significados ligados a coração, percebemos que esse termo também encontra-se no ponto mais elevado de outra escala, desta vez relacionada à vida humana. O mesmo Biedermann acentua o papel capital do coração "como órgão central da circulação sanguínea, indispensável à conservação da vida” (BIEDERMANN, 1993, p. 104), enquanto Juan-Eduardo Cirlot, em seu Dicionário de símbolos, após afirmar que "no esquema vertical do corpo humano, três são os pontos principais: o cérebro, o coração e o sexo", salienta que o ponto "central é o segundo, [o coração, que] por esta própria situação adquire o privilégio de concentrar de certo modo os outros dois" (CIRLOT, 1984, p. 180).

Assim, ao escolher a alegoria de "quem devora o coração de leão", Sophia colocou seu sujeito poético na posição privilegiada de alguém que, ao assumir para si o órgão mais privilegiado do mais privilegiado dos animais, afirma, para si mesmo uma posição extremamente humana, no sentido do homem como o ser superior da natureza e merecedor, portanto, de uma total integração com o universo.

Quanto à caça, ao comentar que, na Grécia antiga, eram bastante freqüentes as lendas que se referiam às caçadas, Thibaud lembra que a "caça era uma escola que ensinava o domínio de si mesmo, privilegiando a coragem, a inteligência e a resistência" (THIBAUD, 1996, p. 144). Na primeira estrofe de "Arte Poética", o sujeito deseja claramente comungar com o esplendor do mundo, emprestando sua própria voz à "veemência das coisas". Homem e mundo estariam, assim, intrinsecamente ligados um ao outro - operação de certa forma semelhante, para ficarmos ainda na metáfora da caçada, à apontada por Thibaud, ao notar que os deuses gregos "participavam das grandes caçadas, ou influenciavam seu desenrolar", transformando-se "eles mesmos em caçador ou em presa". (THIBAUD, 1996, p. 144).

Em “Arte Poética", o sujeito isolado em seu "quarto penumbroso", está mais numa atitude de caçador, atento ao que acontece ao seu redor, e interessado no mundo que o cerca, para além das penumbras. Temos, de um lado, o "quarto penumbroso"; do outro, o "mundo exterior", pedindo a atenção do sujeito para a "veemência" das coisas.

A "veemência" do mundo real constitui, justamente, uma das características mais presentes na obra de Sophia, não só em seus poemas, mas também em seus textos. Entre estes últimos, destaca-se, inclusive por ser bastante citado, o discurso 
que ela pronunciou, ao receber um prêmio por seu Livro sexto, em 1964. Reproduzimos o primeiro parágrafo:

A coisa mais antiga de que me lembro é dum quarto em frente do mar dentro do qual estava, poisada em cima duma mesa, uma maçã enorme e vermelha. Do brilho do mar e do vermelho da maçã erguia-se uma felicidade irrecusável, nua e inteira. (...) (ANDRESEN, 2001, p. 7)

Novamente recorremos àquele leitor ideal de Sophia, conhecedor não só de toda poesia dela, mas também da obra de outros poetas, inclusive dos brasileiros seus contemporâneos. Sabendo muito bem o que estava dizendo, a própria Sophia salientou que "o leitor ideal é o bom poeta”, em entrevista a Denira Rozário (ROZÁRIO, 1994, p. 37). Pois bem, não é difícil associar a "maçã" do discurso, "enorme e vermelha", “poisada em cima duma mesa" num "quarto", àquela descrita por Manuel Bandeira (outra vez ele) em "Maçã” (de Lira dos cinquent'anos, de 1940), poema no qual, nas palavras do professor Davi Arrigucci Júnior, "mais uma vez o quarto surge (...), como o reduto da interioridade do sujeito, espaço lírico por excelência" (ARRIGUCCI JR, 1990, p. 23).

Teríamos muito a falar sobre os muitos entrelaçamentos que ocorrem entre os poemas de Sophia e os de Bandeira, inclusive em relação ao quarto ${ }^{8}$. No entanto, para não perder o fio da dissertação, voltemos ao tema deste capítulo, qual seja a análise do silêncio e do quarto, na poesia de Sophia. Vejamos “As Nereides”, poema também de Geografia, no qual o quarto encontra-se "denso de silêncio puro":

Pudesse eu reter o teu fluir, ó quarto,

Reter para sempre o teu quadrado branco

Denso de silêncio puro

E vida atenta

\footnotetext{
${ }^{8}$ Meu ensaio "O quarto, figuração do intimismo na poesia de Manuel Bandeira e na de Sophia de Mello Breyner Andresen", apresentado em comunicação e incluído nos anais do X Congresso Internacional da Abralic, em CD-Rom, analisa, em maior detalhe, o espaço do quarto na obra de ambos os poetas. De Sophia, são discutidos três poemas, "Manuel Bandeira", de Geografia; "Dia do Mar no Ar" e "Passam os Carros", de Coral, mais o fragmento de um texto, "A coisa mais antiga de que me lembro". De Bandeira, cinco poemas: "Poema do Beco", de Estrela da manhã; "Maçã", e "O Martelo", de Lira dos cinquent'anos; "Comentário Musical" e "Chambre Vide", de Libertinagem. (AZEVEDO, 2006)
} 
Reter o brilho

Da Cassiopeia em frente da janela

Reter a queda

Das ondas sobre a areia

E habitar para sempre o teu espelho

Que dos meus ombros jamais tombasse o tempo

Marinho misterioso e antigo

Assim como as nereides

Não perderão jamais seu manto de água (ANDRESEN, 1999, p.78)

Não passa desapercebida a profunda afinidade semântica deste "denso de silêncio puro", com aquele "quarto (...) pleno" (grifos meus), de "Manuel Bandeira". Por outro lado, Sophia, como sempre, insiste na constante retomada dos mesmos vocábulos: aqui, a "vida atenta" é sublinhada pelo mesmo adjetivo de "minha mente (...) atenta" (grifos meus), de "Arte Poética".

Ao lado do silêncio, o que mais chama a atenção em "As Nereides" é a contínua referência à eternidade, a partir do "para sempre" do segundo verso, repetido no nono e convertido no "jamais", que aparece duas vezes, na última estrofe. Para o efeito deste tempo eterno que nunca tomba (o enunciado é do poema, "que dos meus ombros jamais tombasse o tempo") contribui, além da constelação de Cassiopéia, "em frente da janela", o desejo de "Reter a queda/ Das ondas sobre a areia", sublinhando o movimento constante da maré, que ilustra o contínuo fluir do tempo.

Na verdade, a vontade de "Reter o brilho/ Da Cassiopéia em frente da janela" (o verbo "reter" aparece três vezes no poema) está diretamente relacionado a um dito popular citado por Biedermann, o "querer buscar as estrelas no céu", pois "tentar alcançar as estrelas significa procurar conseguir o impossível” (BIEDERMANN, 1993, p. 147). Ou seja, para o homem, ver realizado o seu desejo de plenitude cósmica, pode ser algo tão irrealizável quanto "reter o brilho" das estrelas, devido à própria condição humana, mortal e finita.

Colocada em oposição à finitude humana, a eternidade é sugerida não apenas pela constelação e pela "queda/ Das ondas", mas, também, pela evocação de um tempo "misterioso e antigo", este associado às míticas "nereides". 
Podemos definir o mistério como algo difícil, senão impossível, de ser compreendido pelo homem - ou, segundo a Grande enciclopédia portuguesa e brasileira, algo "cuja compreensão está acima da razão humana, [...], aquilo que é vago, imponderável, imaterial, incerto e, por isso mesmo, incompreensível", (MISTÉRIO, 1960, p. 398). De certa forma, constituem, também, um mistério aquelas "três mulheres do sabonete Araxá", do poema "Manuel Bandeira", ausentes da realidade imediata, mas capazes de provocar "espanto".

“As Nereides" também lembra "Musa", poema que já focalizamos, não só pela alusão ao espelho e à janela, mas, principalmente, pela cor branca. Se, em "Musa", o quarto era apenas definido como "branco", aqui, em "As Nereides", temos o "quadrado branco", que poderia indicar o cerceamento do espaço ocupado pelo sujeito, dentro dos limites rígidos dessa figura geométrica de quatro lados. No entanto, o quadrado refere-se, também, à necessidade que o homem tem de orientar-se, em meio a um ambiente confuso. Ou, como explica Biedermann: "No caso do quadrado, é fundamental o desejo [do homem] de orientar-se em um mundo que parece caótico, mediante a introdução de direções e coordenadas. A quadratura comporta um princípio de ordem que parece ser inato ao homem [...].(BIEDERMANN, 1993, p. 147)

Nesse sentido, ao ligar o quarto à forma geométrica do quadrado, Sophia, indica o quanto o espaço do quarto é importante para o sujeito estabelecer uma orientação, uma ordenação, uma direção a ser seguida, enfim, num mundo que se lhe apresenta adverso e confuso.

Outro ponto sobre "As Nereides": é dentro do quarto que o eu lírico tenta parar o implacável, para usar um termo do poema, "fluir" do tempo. Se o próprio silêncio pode ser considerado como sinônimo de eternidade, a vontade do sujeito de "habitar" um "espelho" representa um anseio narcísico e irrealizável de prolongar-se para todo o sempre. A sugestão de um sujeito (mais fixado do que refletido, pois lá habita) dentro da irrealidade do espelho contrasta, de modo veemente, com a "vida atenta" da primeira estrofe, por sinal, uma antecipação do estado de atenção encontrado, como já vimos, no posterior "Arte Poética".

O espelho carrega em si próprio uma rica simbologia, na verdade um tanto contraditória, como assinala Biedermann: 
$\mathrm{Na}$ iconografia ocidental, o significado do espelho é contraditório. Por um lado é representado nas mãos das sereias, que conduzem o homem à perdição, [sendo] também atributo da personificação da Luxúria (volúpia e vaidade); por outro é atributo das virtudes que presidem o autoconhecimento, Veritas (verdade) e Prudentia (prudência). (BIEDERMANN, 1993, p. 255)

Ainda em relação aos limites do quarto de "As Nereides", a janela comparece como uma possibilidade de abertura e comunicação para o exterior, representado pelo espaço estelar, símbolo do infinito e da eternidade. A propósito, merece ser lembrada uma observação de Guyer, na sua tese que já citamos, ao identificar as janelas como “as áreas de transferência do saber” (GUYER, 1982, p. 63).

Como nada, na poesia de Sophia, é obra do acaso, a constelação escolhida, Cassiopéia, combina com o clima do poema, extremamente ligado ao mar. Como aponta o ensaísta português Eduardo do Prado Coelho, o mar significa "lugar privilegiado da poesia de Sophia" (COELHO, 1980, p. 22), sendo, como já dissemos, uma das paisagens prediletas da poeta, não apenas em sua poesia, vide, por exemplo o conto para crianças "A Menina e o Mar”, de 1958.

Em “As Nereides", o mar vem ressaltado, tanto pelo adjetivo "marinho", como pelo movimento "das ondas" - movimento, de "queda", para baixo, a sugerir um mergulho nas profundezas, tanto do mar, como do sujeito - e, principalmente, através das "nereides", filhas de Posêidon, que os gregos consideravam o deus do mar.

Aliás, segundo a mitologia grega, Cassiopéia teria sido a vaidosa rainha da Etiópia que ousou comparar sua beleza à das nereides e por causa disso acabou castigada, na pessoa de sua filha Andrômeda, acorrentada a um rochedo (ver Anexo D).

Se atentarmos para o caráter de punição que envolve o mito de Cassiopéia, a menção ao "espelho" ganha um reforço adicional em seu significado narcísico, pois Narciso foi outro personagem mitológico também castigado pelos deuses.

Em relação ao espelho de "As Nereides", o sujeito expressa um desejo ("Pudesse eu") de habitá-lo "para sempre", o que poderíamos interpretar como uma vontade de conhecer melhor a si mesmo e, assim, tentar resolver seus conflitos íntimos. Só que se trata de um desejo impossível de ser realizado, como aponta YvesAlain Favre: "Mas Narciso sabe que a fusão entre ele e seu reflexo, entre o ser profundo e a aparência efêmera, jamais será possível”. (FAVRE, 1997, p. 750)

Enfim, as referências à mitologia grega indicam, por si só, o caráter de eterno que o poema quer passar. A eternidade também surge como pedra de toque no poema 
“Os Dias de Verão", de Dual, 1972, livro de Sophia publicado imediatamente depois de Geografia, que inclui tanto "Manuel Bandeira", quanto "As Nereides", que acabamos de comentar. Segue "Os Dias de Verão":

Os dias de verão vastos como um reino

Cintilantes de areia e maré lisa

Os quartos apuram seu fresco de penumbra

Irmão do lírio e da concha é nosso corpo

Tempo é de repouso e festa

O instante é completo como um fruto

Irmão do universo é nosso corpo

O destino torna-se próximo e legível

Enquanto no terraço fixamos o alto enigma familiar dos astros

Que em sua imóvel mobilidade nos conduzem

Como se em tudo aflorasse eternidade

Justa é a forma do nosso corpo (ANDRESEN, 1999, p. 139)

Através de metáforas precisas, elementos da natureza (ou do cosmos) e qualificativos como "reino", "areia", "maré", "completo", "universo", “astros", “imóvel”, Sophia constrói todo um arcabouço de perenidade, até a própria “eternidade" surgir (“como se em tudo aflorasse eternidade"), na quarta estrofe que, por ser a primeira a conter um só verso, destaca-se sobremaneira das anteriores.

Como já vimos, Sophia devotou grande interesse, não só pela Grécia antiga, mas, em especial, pela estatuária clássica grega, vide seu ensaio $O$ nu na antigüidade clássica, ao qual já nos referimos. Portanto, não fica difícil ler, nas entrelinhas de dois versos do poema, "Irmão do universo é nosso corpo" e "Justa é a forma do nosso corpo", uma referência à perfeição do corpo humano que os gregos antigos buscavam reproduzir (e eternizar) em suas estátuas.

Por falar em estátuas, há um poema de Livro sexto bastante curto, de apenas dois versos, no qual, a estátua, ao mesmo tempo em que aparece sacralizada, de certa 
forma remete o leitor aos "corredores" de "Manuel Bandeira", através das incisivas alusões à "sombra" e ao "silêncio". Trata-se de "A Pequena Estátua":

Presença ritual e tutelar

Companheira da sombra desenho do silêncio (ANDRESEN, 1991, p.

135)

Ainda em "Os Dias de Verão", percebemos que seus "quartos" são definidos por um "fresco de penumbra". Na medida em que o qualificativo "fresco" opõe o interior dos quartos aos "vastos" e "cintilantes" "dias de verão", temos também uma repetição do contraste interior/exterior de "Manuel Bandeira", novamente a sinalizar a inquietação interna do sujeito, contraposta à luminosidade do mundo lá fora. Como vimos em "Manuel Bandeira", a cena do encontro do sujeito com "As três mulheres do sabonete Araxá" acontece em junho, mês que, em Portugal, precede o verão, já anunciando a luminosidade típica dessa época do ano.

Por sua vez, em "Os Dias de Verão", a referência explícita a uma determinada estação, já a partir do título, acaba por salientar o ciclo eterno da natureza, em oposição à precária e finita existência do homem.

Nesse poema, ao irmanar o "nosso corpo" à "concha", perfeita figuração de um espaço diminuto e fechado, Sophia ressalta, de modo veemente, a imagem do sujeito recolhido em si mesmo. Quanto à concha, vejamos um poeta europeu contemporâneo de Sophia, o francês Francis Ponge que, como ela, nutriu profunda obsessão pelo tema das "coisas", além de demonstrar, também, certa predileção pelos elementos ligados ao mar. É de Ponge o texto abaixo, intitulado "A Ostra", do livro $O$ partido das coisas, ou Le parti pris des choses, lançado na França em 1942:

A ostra, do tamanho de um seixo médio, tem uma aparência mais rugosa, uma cor menos uniforme, brilhantemente esbranquiçada. É um mundo obstinadamente enclausurado. No entanto, é possível abri-la: deve-se então segurá-la no côncavo de um pano, usar de uma faca de lâmina desbeiçada e quase cega, recomeçando várias vezes. Os dedos curiosos podem se cortar, as unhas se quebrar: é um trabalho porco. Os golpes que lhe aplicamos deixam círculos brancos em seu invólucro, como se fossem halos.

No interior descobrimos todo um mundo, para beber e para comer: sob um firmamento (propriamente falando) de nácar, os céus de cima afundam-se sobre os céus de baixo, para não formar nada mais que um charco, um sachê viscoso e esverdeado, que flui e reflui frente ao olfato e à vista, arrematado por uma franja de renda com bordas enegrecidas. 
Às vezes, muito raramente, uma fórmula perola em sua goela de nácar, e aí encontramos algo para nos enfeitar. (PONGE, 2000, p. 71)

Comparar a poesia de Sophia à de Ponge, enfim, leva à descoberta de uma rica e interessante série de coincidências e afinidades na obra destes dois europeus que escreveram na segunda metade do século XX ${ }^{9}$. Na verdade, já em 1964, o poeta, ensaísta e professor português Alexandre Pinheiro Torres indicava semelhanças na obra poética de Sophia com a de Ponge, e também com a de outro poeta francês, Eugène Guillevic, no texto "Sophia de Mello Breyner Andresen também no caminho para o concreto", no qual afirma que a poeta, a partir de Livro sexto, assume um “tempo concreto,[...] que a impele para a descoberta do quotidiano das palavras corriqueiras, não carregadas de dourados símbolos olímpicos, o quotidiano da 'janela quadrada', do 'quarto branco', da 'mesa', da 'porta', do 'espelho', do 'copo', símbolos do mundo concreto com que, na realidade - assim nos ensina Guillevic ou Ponge - ombreamos no correr frustre do dia a dia”. (TORRES, 1966, p. 35)

Percebemos que, entre os seis "símbolos do mundo concreto" apontados por Torres, quatro, ou sejam, a "janela quadrada", o "quarto branco" (ambos, "janela quadrada" e "quarto branco", adjetivados exatamente como no poema "Musa"), a "porta" e o "espelho", referem-se a elementos intimistas importantes na poesia de Sophia. De certa forma, como veremos adiante, podemos, ainda, incluir a "mesa" entre esses elementos.

Ainda sobre "Os Dias de Verão", com referência ao lírio e à concha, podemos acrescentar que esses dois ítens são ligados metaforicamente à morte, implicando, assim na transitoriedade da vida do sujeito. Com efeito, como lembra Biedermann, "a simbologia cristã considerava a concha do molusco como imagem do túmulo que encobre o homem após a morte, antes que ele possa ressuscitar" (BIEDERMANN, 1993, p. 103). O mesmo autor, ao se referir ao lírio, depois de mencionar que trata-se de uma flor está associada à imagem dos anjos, assinala que, "no simbolismo popular, o lírio não é apenas o símbolo da pureza, [...] mas também da pálida morte” (BIEDERMANN, 1993, p. 219).

\footnotetext{
${ }^{9}$ Meu ensaio "O homem moderno aprisionado dentro de si mesmo: pontos de tangência entre a poesia de Francis Ponge e a de Sophia de Mello Breyner Andresen" (AZEVEDO, 2005), apresentado em comunicação no I Encontro Paulista de Professores de Literatura Portuguesa, realizado na USP, em 2005, estuda comparativamente os dois poetas, através de três textos de Ponge ("A Ostra", "O Molusco" e "Os Prazeres da Porta"), junto com três poemas de Sophia ("Cidade", "Casa branca" e "As fontes").
} 
Em oposição a esses elementos ligados à finitude, notamos, em "Os Dias de Verão", um certo clima de "festa", a partir do "cintilantes" da primeira estrofe. A "festa" poderia conduzir àquele desejo de totalidade, de união com o cosmos, sentido pelo eu, ao perceber que "O instante é completo como um fruto" e o "nosso corpo", “irmão do universo", como se este sujeito tomasse consciência da possibilidade de sua própria eternidade. Os significados inerentes a "fruto", seja o de simples alimento para o corpo, seja uma possível associação bíblica ao fruto proibido do Paraíso (aqui, cabe lembrar a "maçã enorme e vermelha" daquele discurso de Sophia), ao mesmo tempo que trazem uma certa sacralização, contribuem para revestir o "instante" de rica carga semântica. De qualquer forma, não passa desapercebido, ao leitor atento de Sophia, o carinho especial que ela devota a este termo, transformado, mesmo, em título de um de seus poemas, "Instante", também de Livro sexto:

\author{
Deixai-me limpo \\ $\mathrm{O}$ ar dos quartos \\ E liso \\ O branco das paredes
}

\title{
Deixai-me com as coisas
}

Fundadas no silêncio (ANDRESEN, 1991, p. 136)

A plenitude do "instante" reflete-se no desejo do sujeito de trazer, para os "quartos", a limpeza, a lisura e o "branco das paredes", como se, na verdade, a sua vontade fosse a de limpar-se a si mesmo, abrindo lugar para o "silêncio" encontrado nas "coisas", não sendo demais insistir no fato de as "coisas" constituírem termo semanticamente importante para Sophia, sempre privilegiado pelo seu léxico poético.

Quanto ao "branco das paredes", temos, ainda uma vez, a cor branca, como em "Musa" e em outros poemas que já examinamos. Seria interessante comparar as ocorrências dessa cor, até agora assinaladas e sempre em relação ao quarto, na poesia de Sophia. No poema "III", de No tempo dividido, “As paredes são brancas e suam de terror", associando a cor ao medo e ao estado de enclausuramento vivido pelo sujeito, pois "Tudo é como eu fechado e interior". Já em "As Nereides", de Geografia, o sujeito deseja "reter" (o verbo é mencionado duas vezes) "para sempre" o "quadrado branco", adjetivação que faz o "branco", por significar uma ausência de cor, enfatizar 
a figura do quadrado, demarcando e limitando (além, como vimos, do sentido de orientação proporcionado por essa figura quaternária) o espaço do quarto ocupado pelo sujeito.

Por sua vez, em "Instante", o branco "das paredes" relaciona-se a uma ânsia de limpeza por parte do sujeito, num sentido próximo ao de purificação, ligada ao "silêncio" no qual "as coisas" estão fundadas, implicando num momento primordial do universo, ainda não contaminado pelo homem. Esse momento, ou “instante”, para utilizarmos o vocabulário do poema, seria anterior à própria instituição da linguagem, daí o "silêncio" - que, como num círculo vicioso, nos conduz, de novo, a "Manuel Bandeira".

Ainda está para ser feito um levantamento total da presença do branco na obra poética de Sophia, embora tudo indique que seja esta a cor mais assiduamente citada pela poeta. A professora Maria de Fátima Marinho, ao comentar que as "cores, adjectivando os mais variados substantivos, destinam-se a intensificar as sensações visuais, que estão em íntima ligação com as tácteis”, elenca 27 dessas adjetivações, das quais dez relacionam-se ao branco, nove ao azul, cinco ao verde e três a outras três cores diversas (vermelho, cinza e roxo) (MARINHO, 2001, p. 65). Não dá para concluir nada de definitivo quanto a esse levantamento, pois além de a professora não citar o amarelo (vide "Manuel Bandeira"), as nove citações do azul, na verdade, poderiam ser reduzidas a oito, já que por duas vezes essa cor está ligada a um mesmo elemento, a noite.

Retomando o que estávamos tratando a propósito de "Instante", recorremos a um outro poema de Livro sexto, intitulado, "No Poema", no qual a magia do "instante real" está diretamente ligada ao "gesto claro", ou seja, definido e concreto, "da mão tocando a mesa" (a mesa é também um perfeito exemplo de concretitude):

Transferir o quadro o muro a brisa

A flor o copo o brilho da madeira

E a fria e virgem liquidez da água

Para o mundo do poema limpo e rigoroso

Preservar de decadência morte e ruína

O instante real de aparição e de surpresa

Guardar num mundo claro 
O gesto claro da mão tocando a mesa (ANDRESEN, 1991, p. 136)

Ao introduzir "o mundo do poema", Sophia realiza um mergulho metapoético, reportando-se à dificuldade de fazer poesia através de elementos simples (na verdade, "as coisas") como "o quadro o muro a brisa/ A flor o copo o brilho da madeira". No fundo, a mímesis que ela pretende é eternizar todos esses elementos num "instante real", momento de revelação e "de surpresa", mas ao mesmo tempo espontâneo e natural, como "O gesto claro da mão" que se aproxima da "mesa". Esta representa algo a mais que um mero item de mobiliário, pois carrega todo o significado de ser a peça que oferece o alimento para o homem - ocasião para lembrar, novamente, tanto aquele discurso, no qual Sophia refere-se à "mesa", na qual estava "poisada" "uma maçã enorme e vermelha", como o poema "Musa", que traz uma "mesa" tocada pela "tarde".

Ainda sobre a mesa, Vivian Steinberg, em sua dissertação, salienta a importância da ocorrência desse móvel, nos poemas de Sophia, juntamente com a das paredes:

Já apontamos como elementos concretos para Sophia são fundamentais na arte poética[;] aqui esses elementos estão representados pela mesa e pelas paredes, objetos [sic] domésticos que nos remetem a situações geográficas [sic] determinadas: à casa, à moradia, à imagem do cotidiano [...]. (STEINBERG, 2006, p. 84)

Não deixa de ser interessante notar que a mesa leva Vivian a também associar Francis Ponge à Sophia, citando um livro dele, A mesa (La table, de 1981) ${ }^{10}$. Enfím, lembramos que a mesa é um dos "símbolos do mundo concreto", cujo significado "quotidiano" foi lembrado por Alexandre Pinheiro Torres no já citado texto em que aponta o "caminho concreto" de Sophia.

Ainda quanto a "No Poema", mesmo que nele não apareça o cenário do quarto, a referência ao "quadro" aponta para um espaço confinado, enquanto o "muro", significando tanto separação, quanto defesa, recorda a fragilidade do indivíduo. A procura de um antídoto para a "decadência morte e ruína" representa uma tentativa de anular essa fragilidade, já que "O instante" "de surpresa" indica a possibilidade de um

\footnotetext{
${ }^{10}$ A própria Sophia foi leitora de Ponge, como revelou numa entrevista a Ricardo de Araújo Pereira, para o Jornal de Letras. Após reconhecer que é "uma pessoa pouco reflexiva e analítica", ela lembra-se de citar o poeta francês: "isso é uma frase do Francis Ponge, Sem dúvida não sou muito inteligente. Pelo menos, as idéias não são o meu forte”. (PEREIRA, 1997, p.6)
} 
"mundo claro" para além do "quadro" e do "muro", mundo esse já vislumbrado na existência da "flor", no "brilho da madeira", material natural, portanto puro (em "Musa", o sujeito refere-se ao "chão/ De madeira lavada"), ou na "liquidez da água", esta absolutamente "virgem".

O "mundo claro" está significativamente definido como "do poema", apontando para a significância perene e eterna da própria poesia. $\mathrm{O}$ verso "O destino torna-se próximo e legível” apresenta, em "No Poema”, a mesma hipótese de salvação sugerida por "Os Dias de Verão", no qual a eternidade parece estar a pouca distância do homem, intermediada, não por uma janela, mas pelo "terraço" do qual os "astros" são avistados. O terraço representa, inclusive, uma mediação mais suave, mais fácil de ser penetrada, do que uma janela. Com efeito, a janela barra a passagem do indivíduo; quanto ao terraço, basta abrir uma porta, talvez subir um ou dois degraus e pronto, estamos dentro dele.

Do outro lado do terraço, repetimos, "o destino torna-se próximo e legível”, sinalizando uma saída de salvação para o homem contemporâneo. Sim, a possibilidade de esperança existe, fazendo lembrar o par de versos "Porém a poesia permanece/ Como se a divisão não tivesse acontecido", de "Habitação". Poderíamos, então, ler o nosso próprio destino nos astros, hipótese de leitura (afinal, a poesia também existe para ser lida) acessível, mas um tanto misteriosa (já que exige uma certa decifração), aproximando entre si o "enigma familiar dos astros" e o próprio mistério íntimo do homem.

Ao analisarmos o terraço como elemento de mediação penetrável, interposto entre o sujeito abrigado em sua casa ou em seu quarto, e o mundo exterior, vale recorrer ao poema "Casa Branca", de Poesia I, no qual esta mediação é representada pelo jardim:

Casa branca em frente ao mar enorme,

Com o teu jardim de areia e flores marinhas,

E o teu silêncio intacto em que dorme

O milagre das coisas que eram minhas.

A ti eu voltarei após o incerto

Calor de tantos gestos recebidos 
Passados os tumultos e o deserto

Beijados os fantasmas, percorridos

Os murmúrios da terra indefinida

Em ti renascerei num mundo meu

E a redenção virá nas tuas linhas

Onde nenhuma coisa se perdeu

Do milagre das coisas que eram minhas. (ANDRESEN, 2001, p. 31)

Escolhemos este poema não apenas por ser mais um exemplo da recorrência da casa, da cor branca, do mar e das "coisas". Na verdade, ele marca a primeira vez que Sophia, em sua poesia, nomeia a casa, que aqui aparece como um espaço relativamente pequeno, em relação à imensidão do mar. Sua cor é branca, por um lado lembrando uma tipicidade da arquitetura popular portuguesa, em especial no Algarve e no Alentejo ${ }^{11}$, as duas regiões localizadas mais ao sul de Portugal, mas também trazendo nessa cor toda a carga imagética da pureza, da simplicidade.

"Casa Branca" resume vários dos atributos que, como já vimos, são freqüentemente associados à casa, destacando-se a sua função de refúgio contra "os tumultos e o deserto", abrigo ao qual o sujeito estará sempre desejando regressar (“A ti eu voltarei”), pois nele vê uma possibilidade de renascimento e redenção. Há, também, menção às lembranças da memória, ao mesmo tempo em que é enfatizado o ambiente de silêncio, silêncio "intocado", ou seja, imune às interferências de uma contaminação provocada pelo exterior adverso. Além disso, o sujeito vê na casa a possibilidade de repouso, atividade íntima por excelência. A propósito, o verso “milagre das coisas que eram minhas", repetido duas vezes, no fim da primeira e da última estrofe, vem, através do possessivo, justamente salientar essa intimidade. Uma

\footnotetext{
${ }^{11}$ A respeito da presença freqüente da cor branca, na arquitetura tradicional de Portugal, consultar, entre outros, A arquitetura popular portuguesa, de Mário Moutinho e $O$ que vi em Portugal, de Horacel Cordeiro Lopes. Moutinho relata que "a cor mais característica [das casas] do Alentejo é sem dúvida o branco, com que são caiadas as paredes [...] exteriores e interiores" (MOUTINHO, 1979, p. 118), lembrando também que "no Algarve, como no Alentejo, é o branco a cor mais recorrente nas caiações" (MOUTINHO, 1979, p. 141). O livro de Lopes traz um interesse especial, por se tratar do depoimento de alguém nascido no Brasil: "Muito me impressionou a bela paisagem [do Algarve] [...] em suas praias pitorescas [...] no conjunto gárrulo de suas casinhas brancas, bem caiadas" (LOPES, 1956, p. 115) e "Como são belas as casinhas das aldeias! Brancas como a neve, ostentando as suas chaminés rendadas" (LOPES, 1956, p. 133).
} 
linha pontilhada, parecendo dividir o poema em dois, vem logo abaixo de quando o verso é citado pela primeira vez, como que a sublinhá-lo.

É importante observar o jardim, como um espaço intermediário entre o mar e a casa, intermediação ao mesmo tempo árida e amena, "jardim de areia e flores marinhas". Cabe lembrar que a poesia de Sophia está sempre recorrendo aos contrates, às oposições, fato apontado por Vivian Steinberg:

Sophia [...] ficou conhecida como uma poeta da positividade ou da luminosidade, mas ao mesmo tempo seus poemas mostram um inconformismo com a banalidade do mundo exterior, do qual ela se mostra exausta. Sua obra é construida por tensões entre contrários. Desde seu primeiro livro, Poesia I, há uma oposição: por um lado, (...) "o rumor e vaivém sem paz das ruas" e, por outro, (...) "aquela praia extasiada e nua" (STEINBERG, 2006, p. 9, grifo meu).

De certa forma, é também uma tensão entre contrários que se estabelece quando o sujeito de Sophia vê-se colocado entre sua própria intimidade, metaforizada quer pela casa, quer pelo quarto, e o exterior que o cerca. Daí resulta um certo conflito, acentuado pela presença de algo a intermediar o eu com tudo aquilo que se encontra fora dele. Se tal intermediação assume, muitas vezes, o caráter de um verdadeiro obstáculo, a ressaltar ainda mais o isolamento do sujeito (caso, por exemplo, da "parede", em "III", "Instante", "Dual" e "Escrita do Poema", ou do "muro", em "No Poema"), em outras ocasiões temos elementos que podem ser penetráveis (os "corredores" de "Manuel Bandeira", o "terraço" de "As Nereides" e este "jardim"). Ou, ainda, encontramos componentes que possibilitam uma visão, seja para o exterior (como a "janela", também de "Musa" e "As Nereides"), seja para dentro do próprio sujeito (o "espelho", nesses mesmos poemas).

Cabe, aqui, citar Maria Izabel de Bastos Cunha que, em sua dissertação de mestrado, Entre o espelho do mundo e o espelho do texto, refere-se à poesia de Sophia “como uma permanente obsessão pelo 'lado de fora' a conflituar com a indisfarçável sedução exercida pelo 'lado de dentro'. Dividida entre os dois pólos, sua obra oscila entre a interiorização do exterior e a exteriorização do interior" (CUNHA, 1985, p. 7; grifo meu).

Em relação ao jardim, lembramos que este, como o mar, é um dos cenários mais privilegiados por Sophia, em todos os seus livros, não só os de poesia, sendo, por exemplo, ingrediente importante do seu conto infantil "O Rapaz de Bronze", de 
1956 (a propósito, a primeira edição desse conto, pela Moraes, vem ilustrada com reproduções de delicadas gravuras antigas de flores, da coleção da própria Sophia).

Um último ponto, sobre "Casa Branca": o jardim do poema encontra-se impregnado por um "silêncio intacto", de grande importância para o sujeito, pois nesse silêncio "dorme/ O milagre das coisas que eram minhas", com o emprego do possessivo a acentuar, também desta vez, uma relação de profunda intimidade.

Citemos Biedermann, antes de passarmos a outros poemas de Sophia, nos quais o jardim é mencionado: no simbolismo dos sonhos, “o jardim é uma imagem positiva" (BIEDERMANN, 1993, p. 201), segundo uma passagem do psicólogo suíço Ernst Aeppli:

\footnotetext{
"[O jardim] é o lugar do crescimento, do cultivo dos fenômenos interiores da vida. Nele, o curso das estações do ano se complementa de um modo organizado e claro. A vida em toda a sua riqueza de nuanças se manifesta maravilhosamente. O muro que o circunda conserva intactas as forças internas que florescem. [...] É a expressão simbólica para uma evolução psíquica que chega a uma notável riqueza interior" (AEPPLI, 1943, apud BIEDERMANN, 1993, p. 201).
}

Um poema de Dia do mar, "Há Jardins", liga ao jardim ao silêncio através da lira, instrumento musical típico da cultura grega clássica. Ao relacionar o jardim a um mês preciso do calendário, abril, primavera em Portugal e em todo o hemisfério norte, estação salientada pelas “árvores em flor”, Sophia enfatiza o caráter vivificante do jardim, salientado no texto de Aeppli, acima citado.

Segue "Há Jardins":

Há jardins invadidos de luar

Que vibram no silêncio como liras,

Segura o teu amor entre os teus dedos

Neste jardins de abril em que respiras.

A vida não virá - as tuas mãos

Não podem colher noutras a doura

Das flores baloiçando ao vento leve.

Fosse o teu corpo feito de luar,

Fosses tu o jardim cheio de lagos, 
As árvores em flor, a profusão

Da sua sombra negra nos caminhos. (ANDRESEN, 2001, p. 134)

A primeira estrofe descreve o encantamento de um jardim, banhado pela sugestiva luz da lua e propício ao amor. A menção específica do mês de abril, como já salientamos em relação ao "junho" de "Manuel Bandeira", ao referir-se a um determinado mês do ano, lembra o ciclo da natureza, em oposição à precariedade humana. Além disso, o mês de abril está diretamente ligado ao verbo "respiras", enfatizando, portanto, a celebração da vida.

No entanto, a segunda estrofe começa com uma pesada negação, “A vida não virá", contrariando, inclusive, a possibilidade daquele amor anteriormente insinuado, pois o que vem a seguir, "as tuas mãos/Não podem colher noutras", dá a entender que este sujeito, enunciado na segunda pessoa, não conseguirá jamais encontrar um parceiro amoroso. Note-se a repetição do advérbio negativo, reforçando a idéia de pessimismo, pois o que está sendo negado é "a doura/ Das flores baloiçando ao vento leve", significando que estas flores que não podem ser colhidas representam, de certa forma, a negação do próprio jardim.

O tempo verbal da terceira estrofe enfatiza a impossibilidade de uma realização amorosa. O possível efeito regenerador das “Árvores em flor” vem, logo a seguir, anulado pela "sombra negra", talvez uma menção à morte, que amortece, também, a impressão idílica daquele “corpo feito de luar”. Os lagos do antepenúltimo verso, enfim, por transmitir uma imagem de água parada, imprimem ao final do poema um tom de morte ${ }^{12}$.

Mas estávamos comentando a respeito do mês de abril. Um outro poema de Sophia, "Quando", de Dia do mar, cita, também, esse mês que, como veremos a seguir, é um tanto emblemático na cultura portuguesa recente:

\footnotetext{
${ }^{12}$ Poderíamos, quanto a isso, mencionar uma metáfora da escritora portuguesa Agustina Bessa-Luís, que compara o lago a um túmulo, em seu romance Prazer e glória, de 1988: "Eram salas de baile, a última já aberta e sobre o jardim que representava uma vontade de dispersão e de fuga, como se os convidados devessem perder-se e desaparecer nessa imensa galeria a céu aberto, pronta a dar-lhes destino algo absurdo e cruel. Como fazendo-os perecer no lago imóvel e severo como um túmulo, ou deixando-os amarrados a um labirinto de rosas" (BESSA-LUÍS, 1988, p. 14). Citar Agustina não fica totalmente fora de propósito, pois, numa entrevista publicada em 1985, a própria Sophia confessa sua admiração pela escritora: "Os poetas que prefiro são Miguel Torga (sobretudo o dos primeiros poemas) e Jorge de Sena. E também a romancista Agustina Bessa-Luís, cuja prosa tem um extraordinário poder de criação poética” (HORTA, 1985, p. 70).
} 
Quando o meu corpo apodrecer e eu for morta

Continuará o jardim, o céu e o mar,

E como hoje igualmente hão-de bailar

As quatro estações à minha porta.

Outros em Abril passarão no pomar

Em que eu tantas vezes passei,

Haverá longos poentes sobre o mar,

Outros amarão as coisas que eu amei.

Será o mesmo brilho a mesma festa,

Será o mesmo jardim à minha porta.

E os cabelos doirados da floresta,

Como se eu não estivesse morta. (ANDRESEN, 2001, p. 145)

Antes de nos referirmos ao mês de abril em Portugal, notemos que o poema ressalta "As quatro estações à minha porta", constituindo esta menção ao ciclo perene da natureza uma oposição veemente à morte inevitável, vislumbrada pelo sujeito para si próprio, logo no primeiro verso, "Quando o meu corpo apodrecer e eu for morta". Ao destino fatal sempre previsto para o homem, Sophia opõe a eternidade da natureza, aqui representada por três paradigmas sempre privilegiados por sua poética, "o jardim, o céu e o mar". E é com certo júbilo que o sujeito comemora o esplendor da natureza, celebrando uma "festa" (de certa forma, a mesma "festa", de "Os Dias de Verão") que, se vem explicitada apenas na última estrofe, já é anunciada pelo "bailar" da primeira.

A "festa" da natureza inclui o "pomar", tipo de jardim no qual se cultivam as frutas, manifestação eloqüente da fertilidade e da abundância verificadas na natureza. Mas a natureza também é pródiga em paisagens de encher os olhos, como os "longos poentes sobre o mar", o próprio poente a indicar o ciclo eterno dos dias que se transformam em noites e depois novamente em dias e em mais outras noites...

Esse ritmo natural de nascer e morrer é acentuado pela hábil utilização das rimas finais dos versos, que vão e voltam, lembrando também o ir e vir do mar, este citado duas vezes no poema. No penúltimo verso, um novo cenário natural, o da "floresta", aqui antropomorfizada através de seus "cabelos doirados". Como já 
notamos, a antropomorfização é um recurso muito utilizado por Sophia, sendo também bastante freqüente a menção aos "cabelos" em sua obra, fato que será mais detalhado no capítulo dedicado à prisão.

Ainda na última estrofe de "Quando", o verso "Será o mesmo jardim à minha porta" liga o jardim à porta, reforçando o caráter de intermediação do jardim, ao mesmo tempo em que enfatiza a importância da porta como símbolo de abertura e passagem entre dois mundos em choque, o do interior, representado pelo quarto (ou a casa), onde o sujeito se isola para dentro de seu próprio íntimo, e o universo exterior adverso. Sobre a porta (e a janela), Guyer reproduz uma citação do filósofo alemão Otto Friedrich Bollnow, retirada da edição espanhola de sua obra Homem e espaço:

\begin{abstract}
Para que la casa no se convierta al hombre en prisión, necesita aberturas hasta el mundo que comuniquen al interior con el exterior de una forma apropriada. Ellas abren la casa para relacionarla con el mundo. Son la puerta y la ventana. Ambas son miembros de conexión que relacionan el mundo de dentro con el de fuera (BOLLNOW, 1969, p. 143, apud GUYER, 1982, p.65).
\end{abstract}

A porta, não custa lembrar, foi também motivo de inspiração para Ponge em $O$ partido das coisas, no texto "Os Prazeres da Porta"

Quanto ao mês de abril, é curioso lembrar que, ao ser vertida para o francês, a canção "Coimbra", uma das mais conhecidas músicas populares portuguesas, com letra de José Galhardo e música de Raul Ferrão, teve seu título modificado para “Avril au Portugal’, na versão traduzida por Jacques Larue e lançada pela cantora Yvette Giraud, em 1950. (Sobre os vários significados do mês de abril em Portugal, consultar o Anexo E, que também traz as letras das músicas citadas.)

Para encerrar este capítulo, mais um poema no qual o silêncio está associado a um jardim: "Jardim Verde", poema curto de Dia do mar, com uma única estrofe de nove versos, que resume de maneira bastante expressiva a inquietação íntima do sujeito, por sinal não nomeado:

Jardim verde e em flor, jardim de buxo

Onde o poente interminável arde

Enquanto bailam lentas as horas da tarde.

Os narcisos ondulam e o repuxo,

Voz onde o silêncio se embala,

\footnotetext{
${ }^{13}$ Em O Partido das coisas, o original de "Os Prazeres da Porta", está reproduzido em francês, na p. 72 e, na p. 73, vem a sua tradução, de autoria de Adalberto Muller e Carlos Loria.
} 
Canta, murmura e fala

Dos paraísos desejados,

Cuja lembrança enche de bailados

A clara solidão das tuas ruas. (ANDRESEN, 2001, p. 92)

Se, nesse poema, é clara a metáfora do jardim como o paraíso edênico, local onde o homem se perdeu ao quebrar sua primitiva aliança divina, a ligação do silêncio com o repuxo transfere ao silêncio toda a carga de significados da água, em especial o seu caráter purificador. A água purificadora seria como uma absolvição que regenerasse o homem após sua queda. Mais ainda, se ligarmos a imagem do repuxo à de uma fonte, poderemos pensar numa associação com a fonte do Paraíso descrita na Bíblia: "A Bíblia menciona os quatro cursos de água do Paraíso, surgidos de uma fonte benéfica que se tornou símbolo da vida eterna e do renascimento" (BIEDERMANN, 1993, p. 165).

Notamos que o primeiro predicado conferido ao jardim, logo na abertura do poema, "Jardim verde e em flor" lembra a primavera, estação do renascimento. Como no poema anterior, "Quando", o ciclo perene da natureza vem expressado, mais uma vez, pela referência ao "poente", agora um "poente interminável". A natureza continua a ser uma festa: para comemorá-la "bailam lentas as horas da tarde", num ritmo cuja suavidade repete-se na ondulação dos "narcisos", flor que é escolhida pela poeta com perfeição, pois traz para o poema a angústia do homem que se perde em sua autocontemplação, numa atitude extremamente solitária. Pois é a solidão que fecha o poema, num verso no qual as "ruas", embora provavelmente refiram-se ao “jardim”, sugerem uma cidade, aqui não nomeada, mas que representa, em muitos poemas de Sophia, cenário de sofrimento para o homem, em oposição a todas as benesses proporcionadas pela natureza.

A presença da fonte, na verdade um "repuxo", desenha um clima de "silêncio", companheiro tão habitual da solidão. Voltamos a Biedermann, que assinala a profunda relação existente entre a fonte do jardim e o "mais íntimo cerne" do eu: "é possível encontrar no jardim da alma, como no paraíso, uma fonte ou uma nascente e uma árvore da vida, uma alegoria do mais íntimo cerne da personalidade do eu, o centro mais profundo da alma” (BIEDERMANN, 1993, p. 201, grifo meu).

Sophia relaciona o silêncio diretamente à "voz" do "repuxo", transferindo para o silêncio a simbologia positiva da fonte, como que salientando a importância do 
estado do silêncio no processo de autoconhecimento do sujeito. Mas não se trata de um processo fácil, mostrando-se, ao contrário um tanto doloroso: a flor mencionada, como já salientamos, é o narciso, não nos deixando esquecer da queda do Narciso mitológico. Aliás, os próprios narcisos carregam, em si mesmos, uma simbologia particular, ao mesmo tempo positiva e negativa, pois como aponta Biedermann, "a flor que leva [o nome de Narciso] é considerada o símbolo da primavera e é associada ao sono, à morte e à ressurreição, porque pode desaparecer no verão, mas na primavera recobre novamente os campos” (BIEDERMANN, 1993, p. 255).

Talvez o verso mais forte de todo o poema seja o segundo, no qual "o poente interminável arde", este "arde" em contraponto ao "verde" do primeiro verso, repetindo dois recursos estilísticos comuns em Sophia, quais sejam, o de chegar à ênfase através da comparação de opostos e o de utilizar, em seqüência, vocábulos que ecoam entre si. Ainda sobre o segundo verso, nota-se que ele reproduz a imagem do poente em chamas de "Corpo a Corpo", poema de Poesia I também com uma única estrofe:

Lutaram corpo a corpo com o frio

Das casas onde nunca ninguém passa,

Sós, em quartos imensos de vazio,

Com um poente em chamas na vidraça. (ANDRESEN, 2001, p. 57)

Em "Corpo a Corpo", o quarto está diretamente ligado ao "vazio", assunto de um capítulo específico desta dissertação, o próximo, no qual desenvolveremos a análise desse poema. O importante, por ora, é salientar que, apesar de curto, "Corpo a Corpo" reforça, e em boa medida, o que vimos dizendo a respeito da obra poética de Sophia, na qual se evidencia o recorrente diálogo entre os poemas, além da constante reiteração de determinados vocábulos e imagens. 


\title{
2. O QUARTO, A NOITE E O VAZIO.
}

A primeira menção ao quarto, na obra poética de Sophia, acontece em Poesia I, num poema de uma única estrofe, de quatro versos, "Corpo a Corpo":

\author{
Lutaram corpo a corpo com o frio \\ Das casas onde nunca ninguém passa, \\ Sós, em quartos imensos de vazio, \\ Com um poente em chamas na vidraça. (ANDRESEN, 2001, p. 57)
}

Embora no poema não apareça o eu, já que a ação descrita tem como sujeito a terceira pessoa do plural, nota-se um clima de profunda solidão, a partir do cenário escolhido, as "casas onde nunca ninguém passa", com uma enfática negativa dupla a reforçar o sentimento de completo isolamento. O sujeito nomeado está "sós", num plural que poderia sugerir sua indefinição. No entanto, o título, "Corpo a Corpo", repetido no primeiro verso, caracteriza uma situação de combate e enfrentamento (evidenciada pelo "Lutaram") que, pela possibilidade de acarretar uma derrota, ou padecimento e dor, torna bem nítida a figura do sujeito passível de sofrimento, mesmo estando no plural. Além disso, a sensação de sofrimento vem acentuada, pois um combate "corpo a corpo" implica numa luta lenta e prolongada. De qualquer forma, o plural faz parte da própria maneira de Sophia escrever poesia, pois em muitos de seus poemas a definição do sujeito não é feita de maneira clara.

Por outro lado, as "casas", longe de sugerirem imagem clássica de abrigo e proteção, como vimos no capítulo anterior, aqui, em "Corpo a Corpo", não proporcionam ao sujeito amparo algum. Pelo contrário, tratam-se de "casas" caracterizadas pelo seu "frio" e pela vacuidade de seus quartos, "imensos de vazio", ou seja, embora aparentemente enormes quanto ao tamanho, na verdade estão completamente desocupados, transmitindo ao leitor uma forte impressão de desolação.

A desolação marca apenas os três primeiros versos, pois, na quarta, há "um poente em chamas na vidraça", opondo-se, de maneira gritante, ao "frio" das "casas" e ao "vazio" de seus "quartos". O contraste entre o interior e o exterior, intermediado pelo vidro das janelas, traz o fogo do pôr-do-sol de encontro à friagem sofrida pelo sujeito. Mas o "poente em chamas" não aparece para aquecer quem está com frio. As "chamas", ao invés de trazerem socorro, sugerem a visão algo apocalíptica de um 
inferno. Ou, talvez, se lembrarmos que Poesia I foi lançado em 1944, em plena II Guerra, o "poente em chamas" poderia sugerir um tipo muito particular de inferno, os incêndios das cidades européias provocados pelos combates. Assim, temos acentuado o caráter doloroso do pôr-do-sol, imagem que sugere o enfraquecimento do próprio sol, ou seja, perda de energia e de vitalidade, sinalizando, portanto, fenecimento.

Como sempre ocorre nos poemas curtos de Sophia - e isso está sendo assinalado no decorrer deste trabalho - também em "Corpo a Corpo" as palavras parecem ser escolhidas pela poeta com cuidado especial, ganhando, assim, realce extra. As "chamas", por exemplo, apesar de aparecerem somente no último verso, sugerem uma imagem poderosa, cuja intensidade é ressaltada pelo contraste com o “frio" e o "vazio", termos cuja importância vem naturalmente realçada pela rima entre eles - trata-se, aliás, de um quarteto de construção um tanto rígida (formal e fria, poderíamos acrescentar), com rimas alternadas e decassílabos heróicos.

Notamos que as "chamas" estão do lado de fora, separadas do interior do quarto pela "vidraça". Nesse sentido, no capítulo de introdução ao seu $A$ poética do espaço, Gaston Bachelard, ao referir-se ao espaço que "concentra o ser no interior dos limites que protegem", lembra que o "jogo do exterior e da intimidade não é, no reino das imagens, um jogo equilibrado". E menciona, logo a seguir, os "espaços de hostilidade" como "espaços do ódio e do combate" que "não podem ser estudados senão referindo-se a matérias ardentes, às imagens de apocalipse" (BACHELARD, 1988, p. 108, grifos meus).

Em "Corpo a Corpo", o desequilíbrio interior/exterior acaba favorecendo as "chamas", pois nelas percebemos uma força imagética maior do que a apresentada pelo "frio" ou pelo "vazio". Além disso, as "chamas" são capazes de indicar um apocalipse, como assinala Bachelard.

No entanto, se pensarmos na constante preocupação de Sophia com a busca de uma integração entre o humano e o divino, como meta de uma perfeição difícil de ser alcançada num mundo dividido, talvez as "chamas" estejam apontando para uma possível hipótese de salvação para o sujeito, encerrado nos "quartos imensos de vazio", das "casas onde nunca ninguém passa". Nesse sentido, é significativa a observação de Ernest Aeppli, citada por Hans Biedermann, a respeito da visão do fogo no céu: "Quando, em sonho, alguém se aproxima de um grande fogo, ou vê o clarão do fogo no céu, isto significa que a presença das forças divinas está próxima" (AEPPLI, 1943, apud BIEDERMANN, 1993, p. 164). 
A vidraça sugere a existência de uma janela, abrindo-se para uma paisagem. Terrível ou divina, a paisagem, do outro lado da janela, acaba por enfatizar a presença do sujeito, no plural, encerrado dentro do quarto, ou melhor "quartos", também num plural que acompanha o plural do sujeito. Mas o plural não atenua o estado de isolamento dessas "casas onde ninguém passa"; pelo contrário, reforça a solidão vivida pelo(s) sujeito(s) e claramente indicada pelo "Sós" que, isolado entre vírgulas, e assim explicitamente enfatizado, inicia o terceiro verso.

Se nos fixarmos em maior detalhe no papel que a vidraça representa no poema, podemos concluir que, ao invés de se comportar como um vidro comum, cuja transparência poderia possibilitar a entrada de luz, ela acaba refletindo para dentro do quarto a imagem das chamas. Assim, ao invés de se abrir para fora, cumpre a função de um espelho, devolvendo de volta para o sujeito a sua própria inquietação interior, seja esta inquietação o pavor frente ao horror das "chamas" propriamente ditas, ou a preocupação com o sentimento do divino, além da percepção humana. Além disso, a vidraça, que fecha a janela, impossibilita um contato direto com o exterior, aumentando o insulamento de quem se encontra encerrado(s) dentro do(s) quarto(s).

Sophia utiliza a imagem do "poente" em um outro poema, "Quadro", de No tempo dividido:

Indeciso ressurge do poente

Aureolado de espanto e de desastres

Em busca do seu corpo dividido

Todas as sombras se erguem das esquinas

E o seguem devagar nas ruas verdes

São como cães no rastro de seus passos

Aberta a porta o quarto surge grave

E os espaços oscilam nas janelas (ANDRESEN, 1991, p. 36)

Como em muitos dos poemas de Sophia, é necessário lê-lo mais de uma vez, para tentar encontrar resposta para algumas dúvidas que podem surpreender um leitor menos atento. Quem "ressurge do poente"? O pronome possessivo do verso "Em busca do seu corpo dividido" (grifo meu) indica a possibilidade de um sujeito na 
terceira pessoa, um indivíduo "Indeciso", logo no início do poema, que, depois, será seguido "devagar nas ruas verdes", por "sombras que se erguem das esquinas", sombras que se assemelham a "cães". A menção aos "cães" introduz um tom de certa forma intimidante, pois faz-nos lembrar da atitude agressiva dos cachorros que latem, ao passarmos em frente às casas cujos jardins eles guardam.

Por outro lado, o cão, "o mais antigo animal doméstico do homem" (BIEDERMANN, 1993, p. 69), vem tradicionalmente associado à fidelidade. Ao comparar os "cães" às "sombras", o poema coloca essas "sombras", ou o que representam em termos de angústia e aflição, como companheiras inabaláveis do sujeito, perseguindo-o constantemente.

As "esquinas" ajudam a compor o contexto intimidante, já que funcionam como obstáculos, da mesma forma como os ângulos, os muros, ou as paredes, em outros poemas de Sophia, impedindo ou atrapalhando a ação do sujeito. Além da obstrução, as "esquinas" sugerem, também, a idéia do inesperado, da surpresa, ou mesmo do perigo, diante de tudo o que pode surgir daquele "outro lado" que não se vê.

Em "Quadro", as "ruas" são qualificadas como "verdes". Ao apor a "ruas" um qualificativo inesperado, Sophia exercita seu vigor poético, da mesma forma como, em "Cesário Verde" (poema que vimos um tanto ligeiramente na Introdução e que retomaremos logo adiante), ela adjetivou, também de maneira original, as "ruas" como "roucas" 2 . No caso de "Quadro", um leitor mais imaginativo pode associar os “verdes” à provável existência de limo, musgo ou, mesmo, águas servidas, todos itens acessórios, mas coadjuvantes eficazes para o estabelecimento da angústia vivida pelo sujeito. Numa outra hipótese, as ruas também podem ser vistas como "verdes" por ocasião do "poente", cuja variação de luz deixa as cores fluídas, variáveis, enquanto o sol se põe e a noite chega.

No início do poema, o segundo verso, "Aureolado de espanto e de desastres", mostra-se um tanto ambíguo: a quem, ou a que, ele se refere? Ao sujeito, aquele indivíduo "indeciso"? Ou ao "poente"? A hipótese que nos parece mais provável é a primeira, ou seja, esse verso estaria, realmente, qualificando o sujeito, o qual se encontra "Aureolado", ou seja, de alguma forma iluminado ou destacado, talvez pela própria luminosidade especial do "poente", esse momento do dia também “indeciso",

\footnotetext{
${ }^{2}$ Em um outro poema de Ilhas, "Casas", Sophia utiliza o adjetivo "roucas" também de maneira incomum, para qualificar "casas". Comentamos sobre isso no Capítulo 1.
} 
entre a claridade do dia que termina e a escuridão da noite que se inicia. Assim, a indecisão da luz do poente soma-se à própria situação do sujeito "indeciso", colaborando para o clima de insegurança sentido no poema. É para tentar escapar de todo esse desgosto - expresso, inclusive, pelo "corpo dividido" - que o sujeito vai procurar o refúgio do "quarto", que "surge grave" na última estrofe. Notamos que a menção do "quarto" é acompanhada pela de dois de seus principais acessórios, a "porta", que lhe possibilita acesso, e a "janela", outro elemento de comunicação/abertura para o exterior. A janela, porém, possibilita uma comunicação menos completa, pois não permite o caminhar através, como a porta.

Repetimos a última estrofe, de apenas dois versos: "Aberta a porta o quarto surge grave/ E os espaços oscilam nas janelas". De certa maneira, o "quarto" está demarcado mais pelos seus elementos, digamos, limítrofes, a "porta" e a "janela", do que pela área que efetivamente ocupa. Na verdade, insiste Sophia, "os espaços oscilam nas janelas" (grifo meu), como a indicar uma vacuidade do "quarto", pois "os espaços" estão fora dele, já que "oscilam nas janelas", e não dentro. Dessa forma, é pouco provável que o "quarto" consiga fornecer ao sujeito o abrigo que ele procura, alternativa que lhe permitiria escapar dos "desastres" da primeira estrofe e encontrar uma solução (um repouso momentâneo? o repouso definitivo trazido pela morte?) para seu "corpo dividido".

Em relação ao "espanto", também mencionado na primeira estrofe, trata-se de um termo ao qual Sophia constantemente recorre, como já assinalamos, ora para descrever um estado do sujeito, quase de admiração, frente a alguma maravilha do mundo, ora, como aqui em "Quadro", em associação às possibilidades imageticamente negativas sugeridas pelo "poente".

Terminamos nossas observações sobre "Quadro", assinalando, mais uma vez, a presença dos "cães" no poema, pois essa imagem nos remete a um outro poema de Sophia, "Cesário Verde", de Ilhas, pelo qual passamos, rapidamente, na Introdução e que, agora, reproduzimos por inteiro:

Quis dizer o mais claro e o mais corrente

Em fala chã e em lúcida esquadria

Ser e dizer na justa luz do dia

Falar claro falar limpo falar rente 
Porém nas roucas ruas da cidade

A nítida pupila se alucina

Cães se miram no vidro da retina

E ele vai naufragando como um barco

Amou vinhas e searas e campinas

Horizontes honestos e lavados

Mas bebeu a cidade a longos tragos

Deambulou por praças e esquinas

Fugiu da peste e da melancolia

Livre se quis e não servo dos fados

Diurno se quis - porém a luzidia

Noite assombrou os olhos dilatados

Reflectindo o temor da luz nas margens

Entre ruelas vê-se ao fundo o rio

Ele o viu com seus olhos de navio

Atentos à surpresa das imagens (ANDRESEN, 1999, p. 139)

Não só pela homenagem que presta ao poeta citado no título, "Cesário Verde" é um dos mais belos poemas de Sophia, construído com especial apuro, tanto na escolha das rimas como na das imagens de cada estrofe. Vale assinalar que o esquema de rimas, $a b b a, c d d c$, é o mesmo utilizado por Cesário em "O Sentimento dum Ocidental, um de seus poemas mais conhecidos e que, como veremos, terá várias de suas passagens ecoadas em "Cesário Verde".

É importante lembrar que Sophia, além de leitora de Cesário, foi sua tradutora, para o francês, pois publicou, em 1970, Quatre poètes portugais, volume no qual traduziu, além de Cesário, também Camões, Mário de Sá Carneiro e Fernando Pessoa. Ao falar sobre Cesário, no prefácio desse livro, ela faz algumas observações que, inclusive, poderiam se referir à poesia dela mesma:

Cesário é um poeta do concreto, um poeta do olhar, da limpeza e da objetividade do olhar, um poeta do olhar saudável. [...] Por sua maneira 
de colocar as palavras à nossa frente, como os objetos que colocamos sobre uma mesa para melhor vê-los, pela precisão de seus termos, pela limpeza de seu realismo, Cesário impõe ao tradutor uma literalidade quase total, palavra a palavra. (ANDRESEN, 1970, p. 85; tradução minha)

A frase "como os objetos que colocamos sobre uma mesa para melhor vê-los" recorda aquele discurso de Sophia, que já mencionamos no Capítulo 1, no qual ela descreve "poisada em cima duma mesa, uma maçã enorme e vermelha", afirmando, a seguir, que “(...) do vermelho da maçã erguia-se uma felicidade irrecusável, nua e inteira" (ANDRESEN, 2001, p. 7).

Percebemos, em primeiro lugar, a importância da "mesa" no vocabulário constantemente utilizado por Sophia, sinalizando a importância dessa peça essencial do mobiliário doméstico, pois é na mesa que o homem prepara seu alimento, é na mesa que o homem come, reunido com a família. É também na mesa que o homem trabalha, estuda, lê, escreve. Já que Sophia refere-se à "objetividade do olhar" e à "limpeza de seu realismo", uma referência complementar seriam as mesas nas quais os pintores costumam dispor os objetos e os elementos naturais que depois reproduzirão em suas naturezas-mortas - e aqui é impossível não citar as naturezasmortas do pintor impressionista francês Paul Cézanne, mais pela luminosidade de suas pinturas, do que pelo realismo propriamente dito.

Ao comparar a maneira como Cesário nos apresenta as "palavras", em seus poemas, aos "objetos que colocamos sobre uma mesa para melhor vê-los", ao mesmo tempo em que define Cesário como um "poeta do concreto", Sophia claramente identifica a sua poesia com a poesia de Cesário. Sophia sempre se mostrou uma poeta preocupada com as palavras, seja na escolha de sua exigente terminologia, seja através de várias poesias e textos, nos quais demonstrou a importância da palavra em si. Para citar apenas um exemplo, reproduzimos "Poema de Helena Lanari", de uma única estrofe, de Geografia. O poema, aliás, possui um interesse todo especial para o leitor brasileiro, não só por ter sido diretamente inspirado por uma nossa conterrânea, amiga de Sophia ${ }^{3}$, mas, principalmente, pela referência específica à nossa língua e à nossa maneira de falar:

\footnotetext{
${ }^{3}$ Sophia conheceu a carioca Helena Lanari, informa Eucanaã Ferraz, quando viajou ao Brasil em 1966, na casa do poeta e pintor José Paulo Moreira da Fonseca, no Rio de Janeiro. Casada com o industrial
} 
Gosto de ouvir o português do Brasil

Onde as palavras recuperam sua substância total

Concretas como frutos nítidas como pássaros

Gosto de ouvir a palavra com suas sílabas todas

Sem perder sequer um quinto de vogal

Quando Helena Lanari dizia o "coqueiro"

O coqueiro ficava muito mais vegetal (ANDRESEN, 1999, p. 81)

"Poema de Helena Lanari" fala da "substância total" das "palavras", definidas como "concretas" e, por isso, igualadas aos "frutos", reunindo tanto a concretitude que Sophia viu em Cesário, quanto a evidência do real simbolizada por aquela "maçã", "poisada em cima duma mesa". Ao insistir na propriedade "vegetal" do “coqueiro", no último verso, Sophia demonstra, ainda uma vez, sua preocupação e seu interesse com as características próprias de cada elemento, ou coisa, do mundo que nos cerca.

Numa estrofe de outro poema de Geografia, "Poesia de Inverno", Sophia refere-se à "palavra-coisa". A estrofe, na verdade, a segunda das quatro partes do poema, é identificada pelo numeral "II":

\section{$(\ldots)$}

II

Pinças assépticas

Colocam a palavra-coisa

$\mathrm{Na}$ linha do papel

Na prateleira das bibliotecas (ANDRESEN, 1999, p. 85)

Lemos, aqui, Sophia reunindo, num só, o conceito de palavra e o de coisa. Será possível, então, pensar numa analogia entre as "palavras” utilizadas por Cesário

mineiro Cássio Umberto Lanari, Helena "dividia com o marido o gosto por colecionar obras de arte e antigüidades. [...] Antes de regressar a Portugal, [Sophia] passou alguns dias na casa de praia da nova amiga brasileira, em Arraial do Cabo, e foram juntas a Ouro Preto. Reencontram-se dois anos depois, em Lisboa, e mantiveram sempre os laços da amizade”. (FERRAZ, 2001) 
em seus poemas, precisas, ainda segundo Sophia, e as “coisas", evidências do mundo real e concreto, que volta e meia celebra.

Por tudo isso, quando Sophia refere-se a Cesário como "um poeta do concreto", salientando a "precisão de seus termos" e a "limpeza de seu realismo", é como se ela estivesse definindo a própria poesia dela, tão grande é a assimilação estabelecida com a de seu antecessor.

Assim, no poema "Cesário Verde", nos quatro versos da primeira estrofe, "Quis dizer o mais claro e o mais corrente/ Em fala chã e em lúcida esquadria/ Ser e dizer na justa luz do dia/ Falar claro falar limpo falar rente", em especial no último deles (que se destaca por sua bela e clara simplicidade), Sophia refere-se ao dizer poético de Cesário, como se estivesse aludindo ao que ela mesma escreve.

$\mathrm{Na}$ segunda estrofe de "Cesário Verde", temos os "cães" que "se miram no vidro da retina" do sujeito, aliás o poeta Cesário, sempre nomeado na terceira pessoa. Ele está percorrendo as "roucas ruas da cidade", num estado à beira do colapso, pois "vai naufragando como um barco". Sem dúvida, os "cães" colaboram para essa situação de crise vivida pelo sujeito, da mesma forma como aqueles "cães", do poema "Quadro", nos levam a visualizar melhor o indivíduo que parece se esgueirar pelas "ruas verdes", fugindo das "sombras" que o aguardam "nas esquinas".

Podemos associar à figura do cão uma conotação profundamente negativa, quando nos lembramos de Cérbero, o monstruoso cão da mitologia grega que guardava a entrada dos infernos. Nesse sentido, Chevalier e Gheerbrant assinalam que "o símbolo bastante complexo do cão" associa-se "à morte, aos infernos, ao mundo subterrâneo, aos impérios invisíveis” (CHEVALIER \& GHEERBRANT, 1999, p. 176). Assim, não seria de todo exagerado se entendêssemos os "cães" que "se miram no vidro da retina" como algo semelhante aos demônios interiores do sujeito, forças tão intensas a ponto de lhe causarem grave sofrimento, provocando alucinações e o conduzindo ao naufrágio.

Ainda sobre o verso de "Cesário Verde", no qual aparecem os "cães", temos a presença importante da "retina" do olho humano, lembrando, como já assinalamos, os dois primeiros versos de um soneto de Camilo Pessanha, "Imagens que passaes pela retina/ dos meus olhos, porque não vos fixaes" (PESSANHA, 1994, p. 112). Os versos de Pessanha aludem à transitoriedade daquilo que o homem vê, ou, num sentido mais amplo, vive. Em ambos os poemas, no de Sophia e no de Pessanha, podemos encarar a "retina" como um obstáculo, a impedir a visão perfeita do sujeito, 
como se existisse uma separação de fato entre a sua percepção interior e tudo aquilo que acontece no exterior. Sophia, ademais, inclui o "vidro da retina", sugerindo, ao mesmo tempo, a transparência do material (o olhar consegue atravessar o vidro de modo pleno) e, numa direção oposta, o seu entendimento como um empecilho entre o sujeito e o que ele vê (da mesma forma como o vidro de uma janela permite a observação da paisagem externa, mas não a comunicação total entre o sujeito e essa paisagem). Em mais outra acepção, o "vidro da retina" funcionaria como uma espécie de lente, filtrando o que o sujeito enxerga (e assim não permitindo uma percepção completa) ou, talvez, aumentando o significado e o perigo das ameaças externas. ${ }^{4}$

De qualquer forma, a "pupila" e a "retina" antecipam a menção aos próprios "olhos" do sujeito, os "olhos dilatados" da quarta estrofe e os "olhos de navio" da seguinte, a última do poema. O olho constitui o "principal órgão dos sentidos do homem", indica Biedermann, "sempre ligado à luz e à capacidade espiritual de ver" (BIEDERMANN, 1993, p. 266; grifo do autor). Por seu turno, Chevalier e Gheerbrant acentuam que o "olhar é carregado de todas as paixões da alma e dotado de um poder mágico, que lhe confere uma terrível eficácia” (CHEVALIER \& GHEERBRANT, 1999, p. 653). Assim ao evidenciar os "olhos", o poema chama a atenção do leitor para a percepção aguda da realidade que o poeta-sujeito Cesário Verde demonstrou em sua obra.

Por outro lado, Sophia envolveu "Cesário Verde" com muito do simbolismo da segunda metade do século XIX, período no qual viveu o poeta homenageado, impregnando o poema com alguns ingredientes típicos da atmosfera decadentista da época. A descrição de um indivíduo "naufragando como um barco", decisiva para a descrição do estado de angústia vivido pelo sujeito, reporta-se à imagem do naufrágio, então muito utilizada pelos poetas portugueses. Um exemplo é o poema "Manhãs Brumosas", do próprio Cesário, do qual reproduzimos apenas a terceira estrofe:

(...)

As irlandesas têm soberbos desmazelos!

Ela descobre assim, com lentidões ufanas, Alta, escorrida, abstrata, os grossos tornozelos;

E como aquelas são marítimas, serranas,

\footnotetext{
${ }^{4}$ A propósito de olhos e vidros, ouçamos Joaquim Nabuco, citado por Paulo Rónai: "Evitai de vos observar ao microscópio. Bons olhos, sem vidros, voltados para o que vos cerca é quanto basta" (RONÁI, 1985, p. 503).
} 
Sugere-se o naufrágio, as músicas, os gelos

$\mathrm{E}$ as redes, a manteiga, os queijos, as choupanas.

(...) (VERDE, 1945, p. 89)

Também em "O Sentimento dum Ocidental”, de Cesário, a imagem do naufrágio comparece, ainda que de maneira indireta, nas estrofes nas quais, errando "pelos cais", o sujeito relembra um episódio da vida de Camões, referindo-se, também, às passadas glórias marítimas portuguesas. Importante notar que o sujeito descreve-se "a cismar", numa atitude caracteristicamente intimista:

(...)

Voltam os calafates, aos magotes,

De jaquetão ao ombro, enfarruscados, secos;

Embrenho-me, a cismar, por boqueirões, por becos,

Ou erro pelos cais a que se atracam botes.

E evoco, então, as crónicas navais:

Mouros, baixéis, heróis, tudo ressuscitado!

Luta Camões no Sul, salvando um livro a nado!

Singram soberbas naus que eu não verei jamais!

(...) (VERDE, 1945, p. 102)

Ainda em "Cesário Verde", ao apresentar o sujeito "nas roucas ruas da cidade", na segunda estrofe, Sophia está indiretamente referindo-se à cidade de Lisboa, que Cesário utilizou como cenário, não só em "O Sentimento dum Ocidental", mas também em outro conhecido poema seu, "Num Bairro Moderno". Ao definir o poeta, na terceira estrofe, como alguém que "bebeu a cidade a longos tragos", Sophia coloca Cesário numa comunhão muito íntima com a cidade, através da utilização de um verbo, beber, que identifica uma necessidade da própria sobrevivência. Por outro lado, a descrição que fecha a estrofe, "Deambulou por praças e esquinas" assinala o lado flâneur de Cesário, que o aproxima de Charles Baudelaire.

Lisboa $^{5}$, enfim, comparece, de maneira muito poética, nos dois versos que iniciam a última estrofe de "Cesário Verde", "Reflectindo o tremor de luz nas margens/ Entre ruelas vê-se ao fundo o rio". Nesses versos, Sophia refere-se de forma familiar, quase íntima, ao Tejo, sem indicá-lo expressamente, enquanto Cesário, após

\footnotetext{
${ }^{5}$ Helena Conceição Langrouva comenta que Sophia, em outro poema, "Lisboa" (ANDRESEN, 1999, p. 247), refere-se a essa cidade como a cidade do vazio e da ausência (grifo meu): "O poema de abertura do livro Navegações tem como título 'Lisboa'. Deveria ser o ponto de partida para as navegações, se a seqüência fosse lógica. É, todavia, o ponto de chegada do sujeito lírico, regressando do Sul. Lisboa é a cidade da indefinição [pois, citando o poema, 'Lisboa' tem 'seu nome de] ser e não-ser', a cidade do vazio e da ausência - 'cruelmente construída ao longo da ausência'. É o dizer do poeta que a vivifica, ou seja, é a palavra transmutada em poesia que condensa a expressão do que é Lisboa. - 'porque digo' [ainda segundo o poema]". (LANGROUVA, 2001, grifo novamente meu)
} 
nomear "o Tejo" na primeira estrofe de "O Sentimento dum Ocidental", ao voltar, mais adiante, a mencionar o rio que banha Lisboa, apenas diz "Reluz, viscoso o rio":

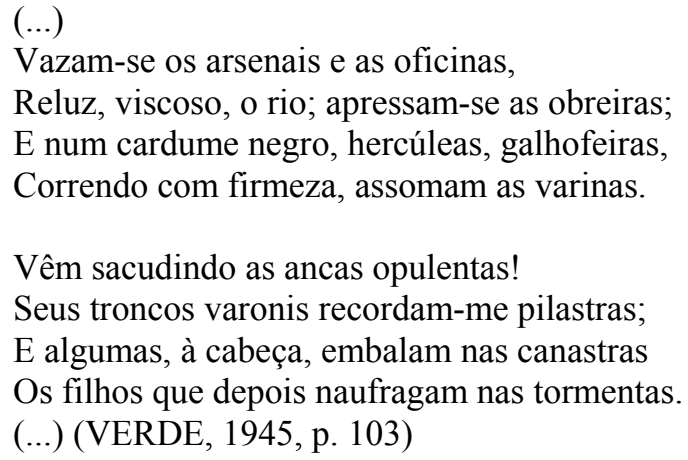

Percebemos que a menção às "varinas" reporta-se, também, à imagem dos naufrágios, através da lembranças dos filhos dessas mulheres que, depois de crescidos, "naufragam nas tormentas". De qualquer maneira, o naufrágio constitui uma imagem de algo muito trágico e triste; um barco que naufraga não volta, não retorna, chega ao fim antes de ver cumprido o seu destino. É nesse sentido que é especialmente dolorosa a menção aos "filhos que depois naufragam", o fio de suas vidas abruptamente cortado; "filhos" (não conseguimos vê-los crescidos) que, provavelmente, deixarão suas mães ao abandono.

Há muito, ainda, em "Cesário Verde", a merecer comentários mais alongados, como a sucessão de contrastes que se repetem por todo o poema. Já nos referimos à clareza da primeira estrofe, através de termos e expressões como "mais claro", "fala chã", "lúcida", "justa luz do dia", além do admirável verso "Falar claro falar limpo falar rente", que, também, recorda o tom quase coloquial empregado por Cesário em "O Sentimento dum Ocidental".

A essa clareza, porém, opõe-se o clima angustiante que domina a segunda estrofe, na qual o sujeito "vai naufragando como um barco". Se, aqui, o "barco" produz uma impressão negativa, na última estrofe, em mais um notável contraste, a mesma figura da embarcação (muito recorrente, vale lembrar, em toda a poesia portuguesa dos séculos XIX e XX), agora como "navio", assume uma posição mais positiva, quando o sujeito tem "seus olhos de navio/ Atentos à surpresa das imagens". Ele, então, coloca-se numa posição semelhante à dos descobridores marítimos portugueses, à procura de novos horizontes, com seus "olhos de navio" funcionando quase como faróis a iluminar o trajeto, embora o último verso, “Atentos à surpresa das 
imagens", implique num resultado nem sempre feliz, pois essa "surpresa" pode significar algum imprevisto desagradável, semelhante às "sombras" que "se erguem das esquinas", no poema “Quadro".

A expressão "olhos de navio" cria uma imagem extremamente sugestiva, pois reúne dois termos de forte simbologia, lembrando, talvez, a figura do "navegador eterno", descrito por Juan-Eduardo Cirlot: "a navegação, numa filosofia do infinito absoluto, negaria ao herói até mesmo [o retorno] à pátria e o faria navegador eterno em mares sempre novos, em horizontes intermináveis" (CIRLOT, 1984, p. 138, grifo meu).

Notamos mais oposições, na terceira estrofe, quando Sophia contrapõe os "Horizontes honestos e lavados" das "vinhas e searas e campinas" às "praças" e "esquinas" da "cidade", referindo-se a detalhes biográficos de Cesário, que viveu entre a loja de ferragens de seu pai, em Lisboa, e o ambiente rural da quinta familiar em Linda-a-Pastora. A menção à paisagem rural sugere, também, certas passagens de poemas de Cesário, como a estrofe que reproduzimos a seguir, de "Nós", na qual o sujeito evoca nostalgicamente "o campo":

(...)

E o campo, desde então segundo o que me lembro,

É todo o meu amor de todos estes anos!

Nós vamos para lá; somos provincianos,

Desde o calor de Maio aos frios de Novembro!

(...) (VERDE, 1945, p. 124)

Encontramos novos contrastes na quarta estrofe, a mesma na qual a palavra "melancolia" ganha certo destaque, ao terminar o primeiro verso, e, sem dúvida, ecoa com o início de "O Sentimento dum Ocidental”, cuja primeira quadra apresenta um nítido tom de confissão intimista:

\footnotetext{
Nas nossas ruas, ao anoitecer, Há tal soturnidade, há tal melancolia, Que as sombras, o bulício, o Tejo, a maresia Despertam-me um desejo absurdo de sofrer. (...) (VERDE, 1945, p. 101)
}

Nessa estrofe, Cesário escolhe, para a confissão de seu sujeito, o "anoitecer". É interessante observar que Sophia, por seu lado, enxerga em Cesário um certo desejo de se ver diurno, através da constatação "Diurno se quis", ainda na quarta estrofe. No entanto, ela a seguir acrescenta, em mais um contraste: "porém a luzidia/ Noite assombrou os seus olhos dilatados", versos nos quais notamos dois pormenores 
significativos: os "olhos dilatados" reportam-se à "nítida pupila" que "se alucina", na segunda estrofe, enquanto a "noite" vem definida de maneira um tanto ambígua, através do adjetivo "luzidia". Embora se trate de um qualificativo mais adequado para evocar o dia do que a noite, "luzidia", relembra uma passagem de "O Sentimento dum Ocidental", na qual, enquanto a noite vem descrita através de seus brilhos, o sujeito, inspirado pelo "fim da tarde", revela seu incômodo íntimo":

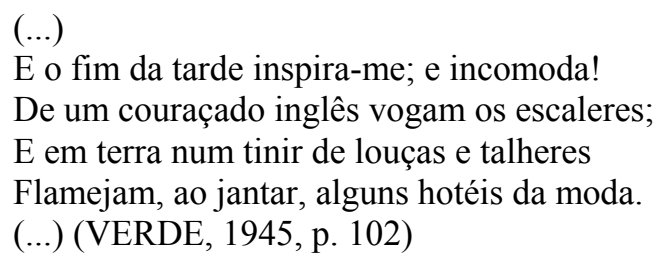

Ainda em relação à quarta estrofe de "Cesário Verde", não podemos deixar de assinalar que o verso "Fugiu da peste e da melancolia" traz uma nítida evocação da primeira estrofe de "Nós":

Foi quando em dois verões, seguidamente, a Febre

E o Cólera também andaram na cidade,

Que esta população, com um terror de lebre,

Fugiu da capital como da tempestade.

(...) (VERDE, 1945, p. 122)

Antes de finalizar nossos comentários sobre o poema "Cesário Verde", vale lembrar um poema de Sophia, que, dedicado a outro "poeta do concreto", o brasileiro João Cabral de Melo Neto, irmana ambos, João Cabral e Cesário, através de "algo" que nos dois "às vezes se alucina". Trata-se do poema "Dedicatória da Terceira Edição de Cristo Cigano a João Cabral de Melo Neto", de Ilhas, do qual reproduzimos a quarta estrofe:

\section{(...)}

Mas sua arte não é só

Olhar certo e oficina

E nele como em Cesário

Algo às vezes se alucina.

(...) (ANDRESEN, 1999, p. 338) 
Como estamos sempre reiterando ao longo deste trabalho, as freqüentes repercussões, entre os vários poemas de Sophia, tornam o leitor cada vez mais consciente de todas as constantes de uma poesia profundamente ligada ao homem, não só em termos do deslumbramento humano frente ao real, mas também considerando o processo íntimo ao qual o homem está sempre se submetendo, na procura de uma melhor compreensão do que se passa em seu interior, inclusive como forma de entender com mais clareza o que acontece no mundo, ao seu redor. Essa é uma das razões pelas quais escolhemos o quarto, sempre presente na poesia de Sophia e que, neste capítulo, pretendemos abordar através de suas relações com a noite o vazio.

Nesse sentido, trazemos, agora, "No Ponto Onde o Silêncio", de Poesia I, poema que, apesar de não mencionar diretamente o quarto, em termos espaciais se caracteriza exatamente pela vacuidade, e não pelo que apresenta de sólido e/ou de concreto. Outra referência espacial importante é a noite, também de interesse específico para o presente capítulo:

\section{No ponto onde o silêncio e a solidão \\ Se cruzam com a noite e com o frio \\ Esperei como quem espera em vão \\ Tão nítido e preciso era o vazio. (ANDRESEN, 2001, p. 75)}

Formalmente, trata-se de uma construção muito similar à de "Corpo a Corpo". Uma das rimas intercaladas, "frio"/"vazio", inclusive, é a mesma. Se colocarmos um poema ao lado do outro, verificamos que eles podem ser considerados como complementares: "No Ponto Onde o Silêncio" ajuda a entender a sensação de vácuo anunciada em "Corpo a Corpo", tornando "o vazio" mais "nítido e preciso", através de elementos característicos do estilo intimista, como o "silêncio" e a "solidão". A esses, junta-se a referência à "espera", sublinhada pelo "em vão", ou seja, infrutífera e, portanto, penosa para o sujeito, que vê seu estado solitário extremamente acentuado.

"No Ponto Onde o Silêncio", portanto, caracteriza uma situação mais trágica do que a que tínhamos em "Corpo a Corpo", poema no qual o sujeito, ao menos, vislumbrava a imagem das "chamas" que poderiam sinalizar a possibilidade de um calor divino, talvez milagroso. 
Quanto à "noite", esta é extremamente importante para a composição de um envólucro intimista, por conta da escuridão predominante, que favorece sobremaneira as operações do sujeito voltadas para o seu próprio interior. Em "No Ponto Onde o Silêncio", a "noite" surge diretamente associada ao "silêncio" e à "solidão", assim como ao "frio", colaborando para a composição de uma perspectiva de ausências, enfatizadas, no terceiro verso, por termos como "esperei”, "espera” (uma repetição) e, principalmente, “em vão". Logo a seguir, o próximo verso, que poderia trazer algo de mais presente, através dos vocábulos "nítido" e "preciso", normalmente utilizados para compor uma definição consistente, acaba constatando, ao contrário, uma total ausência, pois "nítido" e "preciso" qualificam apenas o "vazio", ou seja, o nada.

Sabemos que a noite, por si só, implica num significado todo especial. $\mathrm{Na}$ mitologia grega, para nos atermos a um referente importante na poesia de Sophia, a noite está bastante relacionada a características e sentimentos muito humanos (e íntimos). É o que relatam Chevalier e Gheerbrant, num enfoque predominantemente negativo:

Para os gregos, a noite era a filha do Caos e a mãe do Céu (Urano) e da Terra (Gaia). Ela engedrou também o sono e a morte, os sonhos e as angústias, a ternura e o engano. [...] A noite percorre o céu envolta num véu sombrio, sobre um carro atrelado com quatro cavalos pretos, seguida do cortejo de suas filhas, as Fúrias, as Parcas. (CHEVALIER \& GHEERBRANT, 1999, p. 639)

Dessa visão negativa da noite, apenas escapam, por suas qualidades positivas, o sono (que seria positivo se pensarmos em seu significado, em termos de repouso e de recuperação), os sonhos (às vezes capazes de proporcionar um devaneio saudável, quando apontam uma saída, uma solução) e, evidentemente, a ternura.

Para os gregos, a própria representação da figura da noite, "envolta num véu sombrio" estava ligada ao escuro, à ausência de luz, o que sugere a falta da própria vida. Percebemos que o quadro total dessa representação fica sensivelmente mais lúgubre, mais soturno, devido à inclusão de divindades estreitamente ligadas à morte, como as Parcas, ou às sombras, como as Erínias, nome pelo qual as Fúrias latinas eram conhecidas na Grécia ${ }^{6}$.

\footnotetext{
${ }^{6}$ As Parcas eram divindades infernais incumbidas de fiar, dobrar e cortar o fio da vida humana. Eram três irmãs: a mais nova, Cloto, tecia, na roca, os dias da vida; Laquesis fazia girar o fuso e fiava o destino; finalmente Átropos tornava esse destino imutável, cortando o fio quando media precisamente o comprimento da vida, determinando, assim, o momento da morte. Quanto às Erínias, tidas como filhas da noite, viviam nas sombras e eram divindades vingadoras e perseguidoras dos criminosos.
} 
Também a sabedoria popular associa a noite à morte, como nesta máxima citada por Ulysses Lemos Torres: "A noite iguala os homens, todos ficam negros e com medo; também a morte os nivela, ficam pálidos e imóveis, em cima e embaixo da terra" (TORRES, 1979, p. 22).

Vejamos o que diz Clara Rocha, a respeito da recorrência, em Sophia, do espaço da noite:

A noite é uma presença muito forte [no] primeiro livro de versos [de Sophia] e será um motivo constante em toda a obra, inclusivamente nos contos para crianças. São reveladores títulos como "Noite", "Luar", "O Jardim e a Noite", "Noite das Coisas", "Noites Sem Nome", "Noite de Abril" e "Ó Noite" [todos de Poesia $\left.I^{7}\right]$, sinalizando uma poesia que recupera, ainda que com modulações próprias, o tópos da vivência nocturna do poeta, de larga tradição literária; em Sophia, essa vivência ora exalta a fantasmagoria e o mistério, ora se maravilha com a beleza que a noite traz consigo (sendo o adjectivo "brilhante" um dos preferidos para a qualificar), ora está ligada a um desejo de fuga ou evasão em que ecoa a ânsia mallarmeana de "fuir, là-bas fuir", ora permite o reencontro do eu consigo mesmo no silêncio e na solidão, como no poema "O jardim e a noite". (ROCHA, 2007, grifo meu)

Neste capítulo, dos poemas citados por Clara Rocha, transcreveremos, na íntegra, apenas dois, "Noite das Coisas" e "Noites Sem Nome", por serem os que mais interessam aos tópicos que estamos abordando em nossa dissertação. Por outro lado, “O Jardim e a Noite" será objeto de análise detalhada no Capítulo 3. Quanto ao poema "Noite", de Poesia I, julgamos que devemos nos referir, ao menos, à sua última estrofe, pelo grande grau de identificação que o sujeito nela assume, com o espaço da noite:

(...)

Ó minha noite, em cada imagem

Reconheço e adoro a tua face,

Tão exaltadamente desejada,

Tão exaltadamente encontrada,

Que a vida há-de passar, sem que ela passe,

Do fundo dos meus olhos onde está gravada. (ANDRESEN, 2001, p.

16)

\footnotetext{
${ }^{7}$ O mesmo título de "Noite" identifica, também, mais dois diferentes poemas de Sophia, um incluído em Dia do mar, outro em No tempo dividido. Sobre este último, aliás, falaremos mais adiante, ainda neste capítulo.
} 
Com efeito, na última estrofe de "Noite", o sujeito refere-se à "noite" como "minha", reconhecendo, nela, a existência de uma "face", o que torna bem nítido o diálogo, quase de igual para igual, entre ele, sujeito, e o próprio espaço temporal da “noite”. O verso "Que a vida há-de passar, sem que ela passe", subentende uma alusão à morte, mas a morte, parece ao sujeito menos importante do que a noite, pois ele encontra, nesta última, um sentido de permanência praticamente eterno.

Uma outra leitura do verso poderia indicar a permanência do próprio sujeito, que "morre", mas retorna ao lugar de origem. De qualquer maneira, o sentimento é expresso de maneira bastante íntima, pois "vem do fundo dos meus olhos", local "onde" a face da noite "está gravada".

Já, em "Noite das Coisas", o sujeito não vem nomeado. Porém, encontramos, logo no primeiro verso, duas emoções profundamente humanas, "terror e medo":

Noite das coisas, terror e medo

$\mathrm{Na}$ aparente paz dispersa

Sobre as linhas caladas.

Efeitos de luz nas paredes caiadas,

Gestos e murmúrios de conversa

No mundo estranho do arvoredo. (ANDRESEN, 2001, p. 26)

O "terror" e o "medo" entram em choque, logo a seguir, com a "aparente paz", enfatizada pelas "linhas caladas", que sugerem silêncio. Silêncio? Em flagrante contradição, dois versos depois, deparamo-nos com os "murmúrios de conversa" mas esses ruídos vêm do exterior, identificado pelo "mundo estranho do arvoredo", que parece definir uma paisagem fora dos limites das "paredes caiadas", estas provavelmente circunscrevendo uma casa (ou um quarto), local onde o sujeito não nomeado poderia encontrar abrigo contra o "terror" e o "medo".

O "mundo estranho do arvoredo" sugere a antropomorfização das árvores que descreve, através dos "Gestos e murmúrios de conversa" que poderiam partir do próprio "arvoredo", provavelmente por causa do vento, força da natureza muito citada por Sophia. Aqui, embora não referido diretamente, o vento causaria o movimento dos galhos, daí os "gestos", e o entrechocar das folhagens, que produziria os "murmúrios". Ou, como aponta esta máxima da sabedoria popular, "Ao cair da noite, 
as brancas e tênues nuvens tornam-se densas e negras montanhas e os arbustos apavorantes fantasmas que se movem" (TORRES, 1979, p. 22).

Gostaríamos de assinalar que três vocábulos de "Noite das Coisas" - o "medo", sua rima "arvoredo", mais as "paredes" - foram retomados por Sophia num poema posterior, “Acordo", do livro Coral. Estudaremos esse poema em detalhe mais adiante, no Capítulo 3.

Vamos a "Noites Sem Nome", o último dos poemas citados por Clara Rocha que incluímos aqui:

Noites sem nome, do tempo desligadas

Solidão mais pura do que o fogo e a água,

Silêncio altíssimo e brilhante.

As imagens vivem e vão cantando libertadas

E no secreto murmurar de cada instante

Colhi a absolvição de toda a mágoa. (ANDRESEN, 2001, p. 28)

O poema, que traz um interessante esquema de rimas $(a b c / a c b)$, interessa-nos, em especial, por trazer dois fatores de peso para o estabelecimento da poética intimista, a "solidão", em muitas ocasiões associada, por Sophia, ao vazio no qual o sujeito pode se encontrar, e o "silêncio", objeto de nossa atenção no Capítulo 1. Ambos, a "solidão" e o "silêncio", fornecem, ao sujeito, o afastamento necessário para as operações de introspecção que lhe permitirão conhecer melhor a si mesmo. Nesse sentido, também colaboram as "noites", pelo que trazem de escuridão e, também, de isolamento. Apresentadas no plural, elas marcam a passagem do tempo, embora sejam, logo de início, classificadas como "do tempo desligadas", o que lhes conferiria um estado de supra-realidade, capaz de despertar, no sujeito, uma "solidão" incomensurável, "mais pura do que o fogo e a água", justamente dois elementos representativos da natureza em estado bruto.

O "silêncio", por sua vez, "altíssimo e brilhante", leva-nos em direção às estrelas, constantemente lembradas por Sophia como vetores da eternidade, além dos limites humanos, exatamente por isso nos obrigando a sobre nossa condição mortal. Nesse sentido, vale recorrer a uma observação de Bachelard, apresentada na 
introdução de $A$ água e os sonhos, numa passagem em que discute as relações entre a imaginação e a poesia:

A imaginação não é, como sugere a etimologia, a faculdade de formar imagens da realidade; é a faculdade de formar imagens que ultrapassam a realidade, que cantam a realidade. É uma faculdade de sobre-humanidade. Um homem é um homem na proporção que é um super-homem. Deve-se definir um homem pelo conjunto das tendências que o impelem a ultrapassar a humana condição. (BACHELARD, 1998, p. 18, grifos do autor)

Vale observar que Sophia tem um poema, com uma única estrofe, incluído em Livro sexto, intitulado “O Super-homem”, reproduzido a seguir. Seu quarto verso fornece uma ilustração perfeita para o texto de Bachelard. A notar o estado de solidão ("ia sozinho") deste "super-homem" que, no fundo, talvez de "super" não tenha nada (“encontrei-o na rua”, esclarece o sujeito, como se relatasse o encontro com um mortal qualquer):

Onde está ele o super-homem? Onde?

- Encontrei-o na rua ia sozinho

Não via a dor nem a pedra nem o vento

Sua loucura e sua irrealidade

Lhe serviam de espelho e de alimento (ANDRESEN, 1991, p. 148)

Voltemos a "Noites Sem Nome". Em contraponto ao inalcançável sugerido por "altíssimo e brilhante", dois termos da segunda estrofe, "libertadas" e "absolvição", apontariam para um momento epifânico, ligado ao "secreto murmurar de cada instante", que nos levaria a prestar maior atenção naquilo que nos rodeia, solução, digamos, salvadora, quanto a possibilitar completa integração cósmica. Ou, como expressa a própria Sophia, o momento em que o sujeito conseguiria, enfim, colher "a absolvição de toda a mágoa".

Em relação à freqüente presença das "estrelas" na poesia de Sophia, podemos citar o poema "A Noite", este do livro Mar novo. Trata-se de um poema curto, de apenas três versos:

Sozinha estou entre paredes brancas

Pela janela azul entrou a noite

Com o seu rosto altíssimo de estrelas. (ANDRESEN, 1991, p. 82) 
Nos três versos, Sophia utiliza poucas palavras, para ressaltar alguns de seus mais recorrentes elementos intimistas, como as "paredes brancas" e a "janela", desta vez "azul". A "noite", que entra no ambiente onde se encontra o sujeito, muito possivelmente um quarto, vem novamente humanizada, com "seu rosto altíssimo de estrelas", embora a distância, representada pelo "altíssimo" (mesmo adjetivo de "Noites Sem Nome") relembre que o homem não passa de um reles mortal, frente à eternidade representada pelo espaço cósmico. A condição solitária do sujeito, mais a brancura das paredes possibilita que o leitor imagine um ambiente, ou um quarto, totalmente vazio, a ser preenchido pela "noite", cujas "estrelas", com sua conotação de infinito, poderão, quem sabe, amenizar tanta solidão.

Ainda em relação às "paredes brancas", notamos que a sua cor reporta-se às "paredes caiadas" de "Noite das Coisas", poema que analisamos há pouco. Além de todas as conotações que podemos associar à cor branca, ao insistir nas "paredes caiadas" (na verdade, em diversos poemas), Sophia está recordando, também, uma característica muito típica da arquitetura popular portuguesa, a pintura a cal, quase sempre na cor branca, como notamos no Capítulo $1^{8}$. De qualquer maneira, independentemente de sua cor, as "paredes", comparecem amiúde na poesia de Sophia, no papel de demarcadoras dos limites de um recinto onde o sujeito pode se abrigar. É o caso de "Poema", incluído em Livro sexto e do qual mencionamos somente as duas últimas estrofes, as que nos interessam, em termos de intimismo:

\section{(...) \\ Mesmo que eu morra o poema encontrará \\ Uma praia onde quebrar as suas ondas}

E entre quatro paredes densas

De funda e devorada solidão

Alguém seu próprio ser confundirá

Com o poema no tempo (ANDRESEN, 1991, p. 120)

\footnotetext{
8 “Quadro paredes caiadas" é um verso da canção "Uma Casa Portuguesa”, muito popular na década de 1950 e reproduzida no Anexo E.
} 
Nestas duas estrofes, reparamos, em primeiro lugar, a ênfase que o sujeito coloca em sua própria morte, em oposição à eternidade sugerida tanto pela possível sobrevivência do "poema" (sabemos como é freqüente a criação ter vida mais longa que a de seu criador, o que vem confirmar a diminuta condição mortal do homem), como pelo infinito representado pelo mar, aqui evocado por "Uma praia". Já na estrofe seguinte, temos as "quatro paredes densas" que, por estarem quantificadas pelo numeral "quatro" (aliás enfatizado pela aliteração com "quebra", do verso anterior), não deixam dúvidas quanto ao espaço fechado que delimitam. Espaço fechado, mas vazio, cuja vacuidade vem definida pela "funda e devorada solidão", já que entendemos que quem devora alguma coisa, come sem deixar resto algum.

Quanto ao adjetivo "densas", trata-se do mesmo utilizado por Sophia em "As Nereides", já analisado por nós, que apresenta um "quarto(...)/ Denso de silêncio puro" (ANDRESEN, 1999, p. 54).

O poema a seguir, "Um Pálido Inverno", de Dual, liga, mais uma vez, o quarto, ou melhor, "os quartos", no plural, ao "silêncio":

Um pálido inverno escorria nos quartos

Brancos de silêncio como a névoa

Um frio azul brilhava no vidro das janelas

As coisas povoavam os meus dias

Secretas graves nomeadas (ANDRESEN, 1999, p. 131)

A imagem mais forte do poema é a do "frio", representado tanto pelo "pálido inverno" do título e do primeiro verso, quanto pelo próprio "frio", no terceiro verso adjetivado de "azul", cor considerada fria, justamente por estar associada a elementos que nos transmitem a sensação do frio, como o gelo e a água, ou da distância, como o céu. E mais: quando tomamos por inteiro o verso que se refere ao "frio azul", temos "Um frio azul brilhava no vidro das janelas", com a friagem reforçada por estar localizada num outro material igualmente frio, o "vidro das janelas".

Por outro lado, o "vidro", como em outros poemas de Sophia cumpre uma função de obstáculo, da mesma forma, por exemplo, como aquele "vidro da retina" de "Cesário Verde". Aqui, o impedimento representado pelo "vidro das janelas" age como se fosse uma barreira, impedindo o sujeito de perceber o que acontece lá fora, no exterior.O impedimento é tão grande, que o poema nem menciona essa paisagem 
externa, levando o sujeito concentrar-se apenas no que se passa dentro dos "quartos" e favorecendo, portanto, o mergulho íntimo do próprio sujeito. Assim, o eu-poeta reconhece que "As coisas povoavam os meus dias/ Secretas graves nomeadas", numa constatação que, através do primeiro dos adjetivos indicados, "Secretas", reconhece a intimidade particular dessas "coisas", de interesse privado apenas dele, já que constituem um segredo.

Acabamos de dizer que o sujeito estaria inteiramente concentrado no interior dos "quartos". Há mais um motivo para esse isolamento: o "pálido inverno", que certamente mostrava-se tão rigoroso, a tal ponto que "escorria nos quartos", esses, por sua vez "Brancos de silêncio como a névoa". Note-se que esse último verso traz para o interior "dos quartos" a cor branca e a "névoa", sugerindo, mesmo, a presença da neve, característica dos invernos europeus, invadindo a parte interna desses aposentos. Ora, se o inverno estava tão forte que o sujeito sentia (ou, pelo menos, imaginava) a presença da neve nos “quartos", lá fora o frio deveria estar mesmo insuportável, fazendo o sujeito preferir permanecer dentro, onde, hipoteticamente mais abrigado, teria condições para entregar-se aos seus devaneios íntimos.

Um outro ponto: o adjetivo "pálido", no entendimento popular, é costumeiramente indissolúvel do substantivo "morte", a partir de uma famosa citação proveniente das Odes de Horácio, que repetimos em uma de suas versões, “A pálida morte - Pallida Mors ${ }^{9}$, no original latino - a bate igualmente à porta das choupanas e à porta dos palácios dos reis" (HORÁCIO, 2007) ${ }^{10}$. Nesse sentido, a expressão "pálido inverno", utilizada por Sophia, pode ser entendida como associada à morte (inclusive porque tanto o inverno como a morte lembram imediatamente o frio), o que conferiria ao poema um tom decididamente lúgubre.

Voltermos ao "vazio" e à "noite". O livro Coral traz o poema "Passam os Carros", com sete estrofes irregulares, que reúnem uma série de outros componentes

\footnotetext{
${ }^{9}$ Para a citação original em latim, consultar, entre outros, The Penguin dictionary of citations (COHEN, 1960, p. 197).

10 A expressão "pálida morte" transformou-se num dos lugares-comuns mais utilizados através das épocas e em várias línguas, como nesta estrofe da "Lira XXII" de Marília de Dirceu, de Tomás Antonio Gonzaga (1744-1810), que, na verdade, praticamente reproduz as palavras de Horácio: "O tempo não respeita a formosura;/ E da pálida morte a mão tirana/ Arrasa os edifícios dos Augustos,/ E arrasa a vil choupana" (GONZAGA, 2007). Exemplos, mais recentes, em inglês, colocam a expressão em dois títulos de livros destinados ao consumo de massa, Pale as the dead, da inglesa Fiona Mountain (Londres: Orion, 2003) e Pale death, do casal de norte-americanos Aimée e David Thurlo (Nova Iorque: Tor/ Forge, 2005). Numa máxima à qual nos referimos, neste capítulo, a respeito da noite e da morte, também encontramos a palidez como característica dos mortos.
} 
intimistas para descrever a "solidão" do sujeito encerrado em sua "casa", essa ameaçada por uma ameaça externa, já no primeiro verso:

Passam os carros e fazem tremer a casa

A casa em que estou só.

As coisas há muito já foram vividas:

Há no ar espaços extintos

A forma gravada em vazio

Das vozes e dos gestos que outrora aqui estavam.

$\mathrm{E}$ as minhas mãos não podem prender nada.

Porém eu olho para a noite

E preciso de cada folha.

Rola, gira no ar a tua vida,

Longe de mim...

Mesmo para sofrer este tormento de não ser

Preciso de estar só.

Antes a solidão de eternas partidas

De planos e perguntas

De combates com o inextinguível

Peso de mortes e lamentações

Antes a solidão porque é completa.

Creio na nudez da minha vida.

Tudo quanto me acontece é dispensável.

Só tenho o sentimento suspenso de tudo

Com a eternidade a boiar sobre as montanhas.

Jardim, jardim perdido

Os nossos membros cercando a tua ausência.

As folhas dizem uma à outra o teu segredo, 
E o meu amor é oculto como o medo. (ANDRESEN, 2001, p. 171)

Sophia inicia o poema com uma rápida descrição do mundo exterior, definido de maneira bastante sumária, em apenas três vocábulos: "Passam os carros". À primeira vista, o mundo exterior parece estar distante, longe do momento vivido pelo sujeito, que inclusive não se fixa em nenhuma característica dos carros. Não ficamos sabendo nem de seu tamanho, muito menos de suas cores ou de seus ruídos, sobretudo porque o que parece interessar é mais a definição do instante.

Os carros que passam dão idéia do movimento externo do qual o sujeito deseja se afastar, pois se encontra mergulhado em silêncio e solidão: "tenho o sentimento suspenso de tudo", atitude que bem demonstra seu afastamento de todo o movimento exterior. A imprecisão proposital do mundo externo aponta, justamente, para um dos mais importantes atributos da poética intimista, ou seja, o realce do contraste entre o que acontece lá fora e o que se passa no íntimo do eu-poeta.

Ao mesmo tempo, a passagem dos, digamos, vagos "carros" (certamente esses "carros", descritos em português de Portugal, são os mesmos veículos de transporte coletivo chamados de "bondes" no Brasil), acontece com força e violência suficientes para provocar o tremor da casa. O mundo exterior, que parecia tão remoto, encontrase, na verdade, próximo o suficiente para abalar e ameaçar a integridade física da "casa" - identificada, como geralmente acontece na poesia de Sophia, como o refúgio seguro onde o sujeito pode abrigar-se das ameaças externas.

O principal mote do poema é, na verdade, a "solidão" do sujeito, que vem descrita desde a primeira estrofe, na qual temos "A casa em que estou só". Ou seja, o sujeito está absolutamente sozinho, justamente dentro da "casa", propícia, como já vimos, ao isolamento. Mais adiante, na terceira estrofe, o mesmo sujeito enfatiza sua necessidade de solidão, "Preciso de estar só", enquanto, na seguinte, justifica-se a si próprio, argumentando que prefere "a solidão porque é completa", mesmo que implique em "eternas partidas" e no "Peso de mortes e lamentações".

E mais: a necessidade que o sujeito tem de "estar só" está ligada ao seu sofrimento, ao seu "tormento de não ser", este "não ser" implicando numa percepção de que sua angústia é total, a ponto de colocar em risco a sua própria existência.

Tamanho "tormento" acontece, também porque o sujeito não vê nada ao seu redor, o nada representado pelos "espaços extintos", "pela forma gravada em vazio". Ora, o sentimento de vacuidade, de ausência (e também de impotência: "as minhas 
mãos não podem prender nada"), apresenta-se profundamente ligado a uma operação freqüente na poesia intimista, a da memória. É nesse sentido que o poema refere-se às “coisas" que "há muito já foram vividas", levando o sujeito a se lembrar "Das vozes e dos gestos que outrora aqui estavam".

O passado distante - a distância vem reforçada pelo uso dos termos "há muito" e "outrora" - teria sido povoado por "vozes" e "gestos". Daí depreende-se que a casa, nessa época remota, não estava vazia. O tempo da casa habitada por mais pessoas parece ter sido um passado mais completo, mais alegre, provavelmente o da infância, quando a "casa" era preenchida por uma sensação de felicidade agora inexistente. Inexistente porque o presente é diferente daquele passado: a mesma "casa", hoje, está em situação precária e frágil, abalada por forças externas, invencíveis, as quais o sujeito não consegue dominar, pois se tratam de "combates com o inextinguível".

De certa forma, a casa ameaçada metaforiza a própria situação do eu poético, isolado e impotente para reagir frente aos perigos e intimidações que o rodeiam. E, se estes "combates com o inextinguível" são de tal porte que trazem o "Peso de mortes e lamentações", ao sujeito só lhe resta enfrentar sua própria "solidão", posicionamento no qual ele consegue, afinal, encontrar-se consigo mesmo.

Como uma espécie de antídoto contra seu profundo sentimento de "solidão", de maneira semelhante ao que acontece em "Noite", de Mar novo, poema que vimos há pouco, no qual, "Pela janela azul entrou a noite", o sujeito, aqui em "Passam os Carros", também irá recorrer à noite: "Porém eu olho para a noite/ E preciso de cada folha". A imagem da "folha", de certa forma, antecipa o "jardim perdido" da sétima e última estrofe, "jardim" no qual "As folhas dizem uma à outra o teu segredo", sugerindo, através, mais uma vez, da antropomorfização, um ambiente pleno de compartilhamentos recíprocos, em oposição flagrante à "solidão".

Como já vimos no capítulo anterior, o jardim constitui um espaço privilegiado por Sophia, normalmente ligado a uma série de forças positivas. Se pensarmos, em combinação com o jardim, no par de versos "Creio na nudez da minha vida / Tudo quanto me acontece é dispensável”, podemos imaginar o sujeito desejando para si um estado de pureza semelhante ao existente no paraíso terrestre, antes do fruto proibido, pois o jardim pode ser considerado como uma representação do Éden. A nudez, na verdade, além de ser sinônimo de pureza e inocência, constitui, ainda, o estado natural do homem, sendo, em conseqüência, bastante revelador. 
Ao fazer uma profissão de fé em sua nudez, já que tudo o mais lhe é “dispensável”, o sujeito está se confessando a si mesmo, numa típica atitude intimista, a conversa do eu com o próprio eu. No entanto, o desejo do sujeito de pureza total talvez seja impossível de ser realizado, já que o "jardim" configura-se como "perdido". Assim, ao dialogar consigo mesmo, a memória que o sujeito carrega de um tempo "há muito" vivido traz embutida, justamente, a idéia do paraíso perdido. Paraíso, também no sentido daquela totalidade que o homem só poderia encontrar na natureza, nunca no mundo das máquinas ("os carros").

Em "Passam os Carros", embora não haja menção explícita à dor, os dois versos da penúltima estrofe, "Só tenho o sentimento suspenso de tudo/ Com a eternidade a boiar sobre as montanhas", remetem a uma grande aflição e amargura. Da mesma forma, a dor também está implícita na questão da memória e do mergulho íntimo, em versos como "As coisas há muito já foram vividas" (que pode implicar, inclusive, na idéia de que não valeria mais a pena o sujeito continuar a viver), ou "Peso de mortes e lamentações", que traz três conceitos, todos absolutamente negativos, causa (quanto às "mortes") ou sinônimos ("peso" e "lamentações") do padecimento do sujeito.

Ao se colocar com “o sentimento suspenso de tudo", negando a si próprio o prazer de experimentar, notar, observar, usufruir os prazeres da vida, o sujeito, de certa forma, está pressentido a morte, o fim do homem em oposição à "eternidade" vislumbrada nas "montanhas". Na verdade, o que o sujeito deseja, efetivamente, é uma suspensão - algo que a morte também propicia.

Mesmo que, em "Passam os Carros", não encontremos o ambiente do quarto, outros fatores intimistas que vimos analisando neste capítulo, como a solidão, o vazio e a noite, marcam uma presença importante. $\mathrm{O}$ mesmo acontece em dois poemas que veremos a seguir, "Depois da Cinza Morta Destes Dias", de Coral e "Horizonte Vazio", de Dia do Mar.

O primeiro começa contrapondo os "dias" às "noites" de modo inusitado, pois os "dias", normalmente claros e, portanto, vivos, estão definidos por sua "cinza morta", enquanto as "noites", que esperamos escuras, apresentam-se ligadas ao "branco":

Depois da cinza morta destes dias, Quando o vazio branco destas noites 
Se gastar, quando a névoa deste instante

Sem forma, sem imagem, sem caminhos,

Se dissolver, cumprindo o seu tormento,

A terra emergirá pura do mar

De lágrimas sem fim onde me invento. (ANDRESEN, 2001, p. 159)

$\mathrm{Na}$ verdade, esta aparente troca de atributos vem reforçar o fato de que tanto os "dias", quanto as "noites", afiguram-se, para o sujeito, mortos e vazios, pois ambos, "Sem forma, sem imagem, sem caminhos" (a repetição tríplice da preposição "sem" enfatizando, consideravelmente, o sentido da falta, da vacuidade), estão fadados à dissolução, fim antecipado pelo verbo "gastar". Na verdade, embora a sucessão de cada noite, após cada dia, aí novamente a noite e outra vez o dia, possa evocar o próprio ciclo eterno da natureza, isto parece não interessar ao sujeito, imerso na "névoa deste instante" e vivendo um "tormento" que não lhe permite distinguir nada, nenhuma "forma", nenhuma "imagem" e, muito menos, os "caminhos". Haveria, talvez, uma hipótese salvadora, quase de ressurreição, através da "terra" que “emergirá pura do mar" (grifo meu).

No entanto, Sophia foi bastante clara, ao colocar "emergirá" no tempo futuro e, portanto, distante da realidade vivida no presente pelo sujeito. Está no tempo presente, aliás, o último verbo do poema, utilizado pelo sujeito para se referir ao "mar/ De lágrimas sem fim onde me invento" (grifo meu) e que traduz à perfeição o sofrimento atual.

Apesar das "lágrimas", o "mar" aparece revestido com um significado purificador, de redenção mesmo, no penúltimo verso do poema, ao lavar a "A terra" que, assim, "emergirá pura do mar". Além disso, ao associar o "mar" às "lágrimas" do sujeito, Sophia evoca dois famosos (e muito tristes) versos de Fernando Pessoa, que abrem "Mar Português", no livro Mensagem:

Ó mar salgado, quanto do teu sal

São lágrimas de Portugal! (PESSOA, 2000, p. 60)

A lembrança de Pessoa introduz no poema um pouco da melancolia que é associada ao caráter do povo português, por causa do legado marítimo herdado pelo país, incluindo a epopéia dos descobrimentos, a conquista (e, bem posteriormente, a 
guerra) colonial, o comércio com o oriente e todas as tragédias ligadas a esse processo, como os naufrágios.

Vamos a "Horizonte Vazio", um belo poema de Dia do mar que, ainda sem se referir ao quarto, apresenta, a partir do título, uma decidida impressão de vacuidade:

Horizonte vazio em que nada resta

Dessa fabulosa festa

Que um dia te iluminou.

As tuas linhas outrora foram fundas e vastas,

Mas hoje estão vazias e gastas

E foi o meu desejo que as gastou.

Era do pinhal verde que descia

A noite bailando em silenciosos passos,

E naquele pedaço de mar ao longe ardia

O chamamento infinito dos espaços.

Nos areais cantava a claridade,

E cada pinheiro continha

No irreprimível subir da sua linha

A explicação de toda a heroicidade.

Horizonte vazio, esqueleto do meu sonho,

Árvore morta sem fruto,

Em teu redor deponho

A solidão, o caos e o luto.(ANDRESEN, 2001, p. 143)

Como o "Horizonte" significa uma perspectiva espacial infinita, ao defini-lo como "vazio", Sophia aumenta de maneira considerável o sentimento de oco, de vazio. O próprio “infinito" é expressamente mencionado, na terceira estrofe, relacionado ao "mar", que, por sua vez, não é visto como um todo, mas sim como "um pedaço de mar", colocado num ponto de vista distante do sujeito, "ao longe". Porém, mesmo "longe", o "mar" se destaca, pois "ardia", numa singular operação 
imagística, que combina a água ao fogo, sugerindo, talvez, o sol refletindo-se sobre a superfície do oceano.

O sujeito se dirige ao "Horizonte", colocado no papel de interlocutor, quase como se estivesse frente a um espelho. Na verdade, a sensação do oco parece estar mais dentro do eu, já que, como lemos na última estrofe, o "Horizonte vazio" representa o "esqueleto do meu sonho", ou seja, um "sonho" já consumido e morto, do qual só sobrou a ossatura.

Já na primeira estrofe, o "nada resta" evidencia o sentimento de falta, de algo irrecuperável, que se perdeu lá atrás, num passado longínquo, sublinhado por termos vagos, como "um dia" e “outrora”. O sentido da perda, da carência, é marcado, também, pelos adjetivos "vazias e gastas" da segunda estrofe, colocados em contraponto a "fundas e vastas". Um dos adjetivos, inclusive, volta, em sua forma verbal, "gastou" (trata-se, a propósito, do mesmo verbo utilizado no poema anterior), no último verso da estrofe, no qual o sujeito assume um certo sentimento de culpa, por ter sido o causador, através do "meu desejo", do desgaste das "linhas". Essas "linhas" parecem referir-se ao "Horizonte"; no entanto, como estamos acostumados à linha do horizonte, no singular, o emprego do plural pode significar uma antropomorfização. Ou seja, as "linhas" seriam as linhas do rosto, talvez do próprio sujeito, agora envelhecidas, ou "gastas", devido ao decorrer do tempo.

A memória do sujeito recorda um tempo que passou, sem dúvida mais bemsucedido (nos poemas de Sophia, o passado surge sempre venturoso), pois ligado a uma "fabulosa festa", cujos prováveis faustos são acentuados pela aliteração. Trata-se de um passado irrecuperável, com a irreversibilidade do tempo reforçada, na última estrofe, não só pelo "esqueleto", como também pela "Árvore morta sem fruto", que contrasta intensamente com o "pinhal verde" mencionado antes.

O último verso associa, de maneira dolorosa, a "solidão" vivida pelo sujeito ao "caos" e ao "luto", ligando o estado de isolamento do sujeito aos sentimentos de confusão e perda, provocados pela sensação de finitude.

O passado teria sido uma época luminosa, plena, evocada por passagens como "um dia te iluminou" e "Nos areais cantava a claridade". Mas uma ocasião do passado, que poderia ter apresentado um momento de coragem, a "heroicidade" referida na quarta estrofe, associa essa bravura ao "pinheiro", árvore de porte altivo, mas usualmente encontrada nos cemitérios. 
"Horizonte Vazio" insiste nas imagens inesperadas. A "noite" que, em outros poemas de Sophia, encontramos voltada para a tristeza, a escuridão, a morte, o fim, aqui desce "bailando em silenciosos passos", numa passagem na qual o poema voltase para ele mesmo, pois, através do "bailando", reporta-se à "festa" da primeira estrofe.

"Luar", de Mar novo, é um outro poema que traz a "noite", mas não o quarto. Nele, a primeira imagem associada à "noite" é a dos "jardins suspensos":

Toma-me ó noite em teus jardins suspensos

Em teus pátios de luar e de silêncio

Em teus adros de vento e de vazio.

Noite

Bagdad debruçada no teu rio

País dos brilhos e do esquecimento

Com teu rumor de cedros e teu lento

Círculo azul do tempo. (ANDRESEN, 1991, p. 81)

A imagem de "jardins suspensos" possui uma conotação legendária, pois recorda os jardins suspensos da Babilônia, considerados uma das maravilhas do mundo antigo. Assim, a noite seria um espaço maravilhoso, talvez mágico. No entanto, logo em seguida, ao localizar na noite o "silêncio" e o "vazio", o poema como que quebra a própria magia que havia sugerido, enfatizando duas características da noite muito ligadas à introspecção.

Podemos entender, outrossim, a suspensão como uma atitude, talvez punitiva, da própria noite, que ao trazer as trevas, suspende a luz e todos os fatores de vida a ela ligados, colocando os "jardins" em estado de espera pelo sol do próximo dia. Da mesma forma, durante a noite, o sujeito se colocaria numa posição ansiosa de aguardo, na expectativa da libertação luminosa oferecida pela manhã seguinte.

Embora o poema sugira um cenário árabe, a problemática da suspensão em relação à noite é lembrada por Cirlot através de uma referência à Grécia antiga:

Hesíodo [deu à noite] o nome de mãe dos deuses por ser de opinião dos gregos que as noites e as trevas precederam a formação de todas as coisas. Por isso, como as águas, [a noite] tem um significado de fertilidade, 
virtualidade, semente. Como estado prévio, ainda não é o dia, mas promete-o e prepara-o (CIRLOT, 1984, p. 409).

Num sentido complementar, Chevalier e Gheerbrant assinalam que "as noites eram freqüentemente prolongadas, segundo a vontade dos deuses [gregos], que paravam o Sol e a Lua, afim de realizarem melhor suas proezas" (CHEVALIER \& GHEERBRANT, 1999, p. 176).

Os "pátios" e "adros" aludem a uma cidade antiga, reforçando a evocação da Babilônia, novamente lembrada pela menção a "Bagdad" que, grafada à maneira antiga, costume usual de Sophia, introdua um tom legendário, algo mítico, evidenciando que não se trata da atual Bagdá, mas de uma localidade perdida no “esquecimento". Toda essa memória de um passado muito remoto, marcado pelo "lento/ Círculo azul do tempo"11, envolve o poema em véus (estamos pensando nas odaliscas, personagens das mil e uma noites sugeridas pela atmosfera árabe) de sublime nostalgia, personificada pela "noite", para a qual o sujeito vem pedir abrigo, "Toma-me ó noite".

Mas, que espécie de abrigo o sujeito pode encontrar nos "jardins suspensos", na verdade jardins quase mitológicos, portanto irreais? Talvez os "pátios de luar e de silêncio", estes sim, através da luz tênue e inspiradora da lua, junto com o "silêncio", quem sabe, possam conceder ao sujeito algum tipo de repouso e de sossego interior. No entanto, logo no verso seguinte, "os adros de vento e de vazio", parecem mais capazes de afugentar do que de abrigar alguém, pois tudo o que poderiam proporcionar seria o frio trazido pelo "vento" e o nada representado pelo "vazio". A aliteração entre "vento" e "vazio" enfatiza ambos os elementos, como que empurrando para um as características negativas do outro.

O próximo poema, "Os Mortos de Hecate", de Dia do mar, menciona "os quartos" e é bastante ligado à morte, ou melhor, aos "mortos":

Ao nosso lado os mortos em surdina

Bebem a exalação da nossa vida.

\footnotetext{
${ }^{11}$ Em relação à cor azul, pela terceira vez ela aparece num poema analisado neste capítulo, pois tivemos: "Pela janela $a z u l$ entrou a noite", em "A Noite"; "Um frio azul brilhava no vidro das janelas", em "Um Pálido Inverno"; e, agora, "Círculo azul do tempo", em "Luar" (grifos meus). Isso, de certa forma, vem confirmar o resultado do levantamento feito pela professora Maria de Fátima Marinho, mencionado no Capítulo 1. Depois de relacionar 27 ocorrências de adjetivações envolvendo cores nos poemas de Sophia, a professora assinalou que o azul ocupa o segundo lugar entre as cores mais citadas, logo abaixo do branco.
} 
São a sombra seguindo os nossos gestos,

Sinto-os passar quando leves vêm

Alta noite buscar os nossos restos

Passam nos quartos onde nos deixamos,

Envolvem-se nos gestos que traçamos,

Repetem as palavras que dissemos,

E debruçados sobre o nosso sono

Bebem como um leite o nosso sonho.

Intangíveis, sem peso e só contorno

Ressurgem no sabor vivo do sangue

Sorriem às imagens que vivemos

E choram por nós quando não as vemos,

Porque já sabem para onde vamos. (ANDRESEN, 2001, p. 148)

Em primeiro lugar, cumpre esclarecer a referência à mitologia grega que encontramos no título, a divindade Hécate, ou Hecate, como Sophia a chama. Os mitos ligados a Hécate não chegaram até nós de uma forma consolidada, pois encontramos várias versões sobre sua história e seus poderes, às vezes bem diferentes entre si. Há um consenso, no entanto, no fato de Hécate estar ligada à morte.

Segundo alguns, Hécate teria ajudado a deusa Deméter, protetora da agricultura, em sua busca pela filha Perséfone, raptada por Hades para o reino inferior. Hécate localizou Perséfone e reuniu mãe e filha. A partir de então, Perséfone passou a viver parte do ano com a mãe, parte no mundo inferior, o que explicaria o ciclo anual das colheitas. Como recompensa, Perséfone teria admitido Hécate no Hades e daí derivaria a variante segundo a qual Hécate seria uma carcereira, ou condutora de almas. Após passarem pelo cão Cérbero e por uma espécie de julgamento, os mortos chegariam à encruzilhada dos infernos, ponto a partir do qual Hécate os conduziria para o destino mais adequado a cada um. Num sentido semelhante, no mundo terrestre, Hécate seria a guardiã das cruzamentos. Numa versão que a aproxima da escuridão da noite, Hécate seria, ainda, identificada com a lua nova. Conta-se, finalmente, que o culto a Hécate teria sobrevivido à Antigüidade, através de práticas de magia e feitiçaria 
O mito de Hécate desempenha um papel importante na composição do título do poema, colocando "os mortos", e em conseqüência, a própria morte, numa perspectiva acima do conhecimento humano. Além disso, a figura da divindade salienta a permanência da morte no nosso horizonte, desde os tempos mais remotos.

O sujeito do poema vem nomeado apenas uma vez na primeira pessoa do singular (no quarto verso, através do verso "sinto-os"), sendo vertido para o plural, em todos os demais versos nos quais aparece. Nós, leitores, sentimos esse sujeito na primeira pessoa do plural como uma presença muito próxima a nós, “Ao nosso lado", segundo a advertência do primeiro verso, fazendo com que nós soframos, ao ler o poema, uma aflição bastante semelhante àquela do sujeito. Percebemos, enfim, quão de perto a morte nos persegue, participando mesmo de nossos momentos mais triviais.

A visita dos "mortos em surdina" seria, então, uma antecipação da morte, preparando-nos para que a aceitemos como um acontecimento já esperado. É nesse sentido que os mortos se "envolvem" em nosso cotidiano, "seguindo os nossos gestos", repetindo nossas "palavras", ficando "debruçados sobre nosso sono" e não respeitando nem nossa intimidade mais privada, pois "Passam nos quartos onde nos deixamos".

O significado de "nos deixamos", expressão que liga o sujeito aos "quartos", subentende tanto a atitude de abandono frente a um incômodo ou a um perigo (ou, também, a uma paixão), quanto a postura de quem quer descansar, relaxar, e por isso procura o aconchego desses aposentos. Oferecendo, ao mesmo tempo, abrigo e proteção, o quarto, representa, nesse e em outros poemas de Sophia, um valioso auxílio, desempenhando o papel do ambiente em que o sujeito descarrega sua angústia íntima.

O poema cumpre a função nada agradável de nos alertar de quanto a morte nos é chegada, pois "os mortos" "bebem" (verbo utilizado por Sophia para dar a idéia de transubstanciação, como já notamos a respeito de "Cesário Verde") "a exalação de nossa vida" e também "bebem como leite o nosso sonho".

Todo construído a partir de contrastes, "Os Mortos de Hecate" sublinha a oposição morte/vida. Com efeito, termos de valor positivo, como "vida", "gestos" (esse, repetido duas vezes, na primeira e na segunda estrofe), "palavras", "leite", "sonho", aparecem contrapostos a termos mais negativos, como "mortos", "sombra", “noite", "restos", "sono". Verificamos um contraste todo particular entre os dois líquidos mencionados, "leite", alimento essencial e o primeiro a ser utilizado pelo 
homem, a partir de seu nascimento, e o "sangue", que poderia significar o fluído da vida, mas na expressão "sabor vivo do sangue" está sugerindo, numa espécie de prazer vampiresco, a satisfação cruel de alguém que vê derramado o sangue de uma vítima. Goethe, em Fausto, refere-se ao sangue como "um muito especial estrato" (RÓNAI, 1985, p. 873).

Talvez, numa alusão às características muito humanas que os deuses gregos apresentavam, ou, sob um outro ponto de vista, tentando mostrar, mais uma vez, o quanto a morte está próxima de nós, os "mortos" do poema aparecem descritos quase como se fossem homens, inclusive como seres que "sorriem" e "choram" (em outro contraste). Não nos enganemos, no entanto, pois os "mortos" são "Intangíveis, sem peso e sem contorno". Ou seja, possuem características de intangibilidade e inatingibilidade que os tornam realmente inacessíveis; portanto, podemos concluir que os "mortos" são invencíveis, numa clara sinalização de que da morte não escaparemos.

Ainda em relação à noite, chegamos a "Flauta", de Geografia. Apesar de curto, o poema traz um belo verso, "Estava o anel da noite solenemente posto em meu dedo" e mostra um quarto, em cujo canto "a sombra tocou sua pequena flauta":

No canto do quarto a sombra tocou sua pequena flauta

Foi então que me lembrei de cisternas e medusas

E do brilho mortal da praia nua.

Estava o anel da noite solenemente posto no meu dedo

E a navegação do silêncio continuou sua viagem antiqüíssima.

(ANDRESEN, 1999, p. 47)

Embora conste de apenas cinco versos, o poema apresenta, em cada linha, imagens que, sem exagero, podem ser consideradas deslumbrantes, mas completamente diferentes entre si, o que torna o todo extremamente rico, tanto visual como simbolicamente.

No primeiro verso, temos não apenas o "quarto", mas, mais especificamente, o seu "canto", porção menor, mais íntima, do espaço descrito. Nesse "canto", o sujeito percebe a "sombra", nova insistência de Sophia num ambiente penumbroso que, como a "noite", evidenciada no quarto verso, vem favorecer as operações intimistas. 
É a "sombra" que toca uma "pequena flauta", ecoando uma famosa passagem de Camilo Pessanha, "Só, incessante, um som de flauta chora", do poema "Ao Longe os Barcos de Flores" (PESSANHA, 1994, p. 120). Colocamos em foco apenas um verso de Pessanha; mas em termos desse poeta, como também de Sophia, um verso é suficiente para sugerir toda uma atmosfera, aqui sugerindo solidão, melancolia e tristeza.

A fidelidade de Sophia aos temas e elementos da cultura grega clássica nos faz encarar a flauta como "um instrumento antigo", nas palavras de Biedermann, “associado a uma das nove musas, Euterpe" (BIEDERMANN, 1993, p. 147). Em seguida, ele narra uma das hipóteses mitológicas para a origem da flauta, também chamada de siringe, mesmo nome da ninfa que, para escapar do assédio da divindade pastoril Pã, transformou-se nos caniços que nascem perto da água. Pã, então, utilizou os caniços para confeccionar uma flauta, "para não sentir falta da doce voz da ninfa". ${ }^{12}$

As observações que vimos fazendo sobre a mitologia grega interessam, não só no sentido de estarem ligadas a todas as referências à Grécia Antiga utilizadas por Sophia em seus poemas, mas também pelo que significam na vida do homem de qualquer época. "Quando nos apoiamos em fatos mitológicos”, lemos em Bachelard, "é porque reconhecemos neles uma ação permanente, uma ação inconsciente sobre as almas de hoje" (BACHELARD, 1998, p. 19).

O segundo verso reúne duas imagens, a da "cisterna" e a das "medusas". O termo "cisterna" refere-se, especificamente a um reservatório de água pluvial, de "uso muito antigo", "especialmente no oriente" (CISTERNA, p. 881). Nas regiões carentes de água, a cisterna equivalia a um cofre protegendo um tesouro, como narra uma passagem de Comentários do grande Afonso de Albuquerque ${ }^{13}$ : "por não se fiar da

${ }^{12}$ Uma curiosidade: no dicionário de Biedermann, como ilustração do verbete "heteras" (também hetairas, em português), aparece a pintura de um antigo vaso grego, mostrando uma dessas cortesãs, despida e tocando uma flauta, em um banquete. Na verdade, as heteras eram "as únicas mulheres cultas da sociedade grega, [...] versadas em filosofia, arte e literatura, assim como na música e na dança" (BIEDERMANN, 1993, p. 185). Ainda sobre a flauta e a mitologia grega, Robert-Jacques Thibaud afirma que "a música produzida por esse instrumento encantava os deuses [...]. A deusa Atena possuía uma flauta [...] que tinha a particularidade de gravar na memória os sons que produzia. [...] A flauta era utilizada tanto para marcar a cadência [...] dos ginastas ou dos remadores das naus, como do ritmo dos cantos sagrados nos templos. Instrumento ligado aos personagens míticos e aos pastores, a flauta simbolizava a harmonia produzida pelos elementos primitivos do mundo" (THIBAUD, 1996, p. 262; tradução minha).

${ }^{13}$ O livro, cuja primeira edição é de 1557, refere-se aos de feitos do português Afonso de Albuquerque (1462/1515), Governador da Índia e um dos responsáveis pela expansão portuguesa no Oriente. Foi 
gente, tinha as chaves de todas as cisternas [...] e a água em Ormuz era tão cara, que uma jarra dela, que em tempo de paz valia dez dinheiros, valia agora duzentos" (CISTERNA, p. 881).

Ao escolher o termo "cisterna", Sophia opta por utilizar uma palavra antiquada, pouco utilizada atualmente, que se refere a uma construção também de outros tempos, desatualizada numa era de alta tecnologia. Confere, assim, um tom de fábula ao poema, passando para o leitor uma mensagem preciosa, ligada à sabedoria e à vida mais próxima da natureza dos homens de épocas remotas. Quanto a "medusas", que não aparecem como mero item de enumeração, tratam-se daqueles animais marinhos muito citados por Sophia, de origem explicada pela mitologia grega, pois, vale recordar, teriam nascido do sangue da Górgona Medusa ao ser decapitada por Perseu.

As "medusas" prenunciam o "brilho mortal da praia nua" do verso seguinte, que une a morte a uma "praia nua", cuja nudez inclui o caráter primitivo, puro e revelador implícito no adjetivo, além de se referir, também, a uma paisagem deserta, sem a presença humana.

Depois do "quarto", da "sombra", da "flauta", das "cisternas", das "medusas", da morte, da "praia" e da nudez, número considerável de imagens, para uma pequena estrofe de apenas três versos, há ainda mais.

Falemos antes do "anel”, objeto de grande carga simbólica. Biedermann indica que se trata de um "símbolo tradicional do ilimitado" (BIEDERMANN, 1993, p. 31), do eterno. Ao associar o anel diretamente à noite, na expressão "anel da noite", o poema sugere as possibilidades ilimitadas da noite como fonte de inspiração para o sujeito, notadamente por favorecer condições muito propícias ao recolhimento e à meditação. Nesse sentido, é importante assinalar que "Estava o anel da noite solenemente posto no meu dedo" (grifo meu), salienta a identificação absoluta entre o sujeito e a noite, uma vez que ela é transformada em algo possuído por ele. Além disso, o "solenemente" confere uma certa pompa ao relacionamento sujeito/noite, quase como num ritual (lembremos a importância do "anel” em certas cerimônias, como a do casamento), reforçando, desse modo, a indissolubilidade dessa relação.

No último verso, "a navegação do silêncio continuou sua viagem antiqüíssima". O "silêncio", como já vimos, representa importante ingrediente da 
poesia intimista e aqui aparece como uma conclusão, digamos, definitiva, sobre todos os sinais enviados ao leitor pelo poema. Numa época como a do fim do século XX, marcada, de um lado, pelos avanços tecnológicos superados a cada dia e, do outro, pela insatisfação do homem, ao não encontrar um espaço para si em meio a esse contexto, talvez a solução mais próxima seja a do "silêncio". Bem entendido, "silêncio" não de Sophia, que escreveu como poucos poetas de seu tempo, mas do homem. Afinal, o "silêncio" parece ser tão antigo quanto o homem, "silêncio" sempre pronto a continuar "sua viagem antiqüíssima".

Para terminar o capítulo, uma pequena jóia de Sophia intitulada "Harpa", de $O$ búzio de Cós e outros poemas. Trata-se de um poema de quatro versos, em duas estrofes, trazendo alguns das localizações espaciais mais constantes em Sophia, como o "mar" e o "quarto", além de citar um outro instrumento musical que herdamos da Antigüidade, a harpa. O poema é de grande apelo imagético:

A juventude impetuosa do mar invade o quarto

A musa poisa no espaço vazio à contra-luz

As cordas transparentes da harpa

E no espaço vazio dedilha as cordas ressoantes (ANDRESEN, 2004)

Já que falamos das imagens, comecemos por elas. A do "espaço vazio" é a mais enfatizada, pois aparece duplamente, no segundo e no último verso. Esse “espaço", sem dúvida, refere-se ao "quarto", único ambiente mencionado e bastante singular, pois parece pertencer a um sonho, ao personificar seu único ocupante na figura da "musa", que "poisa no espaço vazio", lembrando um movimento etéreo, talvez o de uma fada. Ou, se pensarmos num ser mais ligado ao mundo real, talvez um pássaro ou uma libélula, únicos capazes de poisar "no espaço vazio".

O próprio "espaço vazio" supõe a irrealidade, mas não um nada absoluto, porque há a presença da "musa", personagem viva, pois "poisa (...) à contra-luz"; no entanto, por ter sido identificada como "musa" e, graças ao atributo da "harpa", seria uma personagem mitológica, ou seja, não real.

Nessa sucessão de contrastes e oposições, o efeito da "contra-luz" contribui para a atmosfera de ilusão, típica do sonho. Ora, como explica Bachelard, "as palavras, pelo devaneio, tornam-se imensas, abandonam sua pobre determinação 
primeira" (BACHELARD, 1988, p. 181; grifo meu). Assim, através do sonho, fica mais fácil entender os excessos de Sophia, em relação à imagem da "musa", ao mesmo tempo real e irreal, caracterizada um tanto em demasia, através dos ímpetos juvenis do "mar".

De qualquer maneira, o sonho é um estado individual, íntimo, sentido por um eu nunca nomeado no poema e que, ao descrever o que vê no "espaço vazio" do "quarto", dirige-se exclusivamente ao leitor, já que não menciona nenhum interlocutor.

A transparência das cordas da harpa colabora para a composição do cenário de sonho e irrealidade. Se associarmos o "espaço vazio" à "praia nua" de "Flauta", podemos pensar num espaço pré-humano, portanto livre de toda a contaminação trazida, posteriormente, pelo homem. Ficaria, assim, justificada a própria presença da "musa" dedilhando a "harpa" (ao utilizar o verbo dedilhar Sophia opta deliberadamente por uma referência direta ao talento manual, habilidade cada vez mais esquecida pela civilização industrializada). Nesse contexto, fica claro que é a “juventude” que está adjetivando o "mar", e não o contrário, assinalando, também, o momento remotíssimo do mundo recém criado.

A tradição conta que a harpa, assim como a flauta, representada no poema anterior, seria um dos instrumentos musicais mais antigos, provavelmente originada dos arcos de caça, que produziam sons ao roçarem na corda e justificariam uma das razões para seu formato triangular. Chevalier e Gheerbrant definem a harpa "como o instrumento tradicional por excelência, em oposição aos instrumentos de sopro ou percussão" (CHEVALIER \& GHEERBRANT, 1999, p. 484).

Não se pode esquecer que a harpa, no imaginário popular e no religioso, é associada aos anjos. Quanto à mitologia grega, Hermes, que John Pinsent apresenta como o "mais jovem e astuto dos imortais", ainda criança, "encontrou uma tartaruga" e "da sua carapaça fez a primeira lira", que seria a ancestral da harpa. (PINSENT, 1976, p. 23). Hermes teria, também, sido o inventor da flauta, construindo a sua antes da de Pã.

Talvez seja uma associação um tanto forçada, ligar a juventude de Hermes, através da harpa, à "juventude impetuosa do mar". De qualquer modo, ao invadir o "quarto", o "mar", jovem e impetuoso, representa uma feliz construção de Sophia, imprimindo ao retrato da "musa" toda a energia das ondas, vigorosas como a "juventude". 
Um verso bem anterior de Sophia, do poema "Quem És Tu", de Poesia I, compara a "juventude" do interlocutor do sujeito poético ao "ardor do vento", valendo-se de uma força da natureza, tão impetuosa quanto o mar. Seguem as três estrofes de "Quem És Tu”

Quem és tu que assim vens pela noite adiante,

Pisando o luar branco dos caminhos,

Sob o rumor das folhas inspiradas?

A perfeição nasce do eco dos teus passos,

E a tua presença acorda a plenitude

A que as coisas tinham sido destinadas.

A história da noite é o gesto dos teus braços,

$\mathrm{O}$ ardor do vento a tua juventude,

E o teu andar é a beleza das estradas (ANDRENSEN, 2001, p. 42)

Apesar da menção à "noite", na primeira e na terceira estrofe, e da "plenitude/ A que as coisas tinham sido destinadas", na segunda, temas, ambos, analisados neste trabalho, "Quem És Tu" aparece, aqui, apenas como sinalizador da maneira como Sophia entendeu a "juventude", em termos de "ardor", ligando-a à força natural do "vento".

Vale mencionar algo a respeito da "juventude" da autoria de Byron, um dos poetas mais do agrado de Sophia, lembrado por ela nos poemas "A Escrita" e "Glosa de 'So we'll go no more a roving' de Byron'. Do primeiro, reproduzimos apenas um verso: "Pudemos imaginá-lo sentado à sua mesa" (ANDRESEN, 1999, p. 328); do segundo, segue a abertura: "Não irei mais meu erro errando errante/ Pela noite fora" (ANDRESEN, 1999, p. 329). Ambos pertencem a Ilhas e, na edição de Obra poética III que utilizamos como fonte, estão em páginas contíguas, um espelhando-se no outro.

Vamos aos dois versos de Byron, sobre a juventude, de "A Peregrinação de Childe Harold", cuja publicação iniciou-se em 1812: "On with the dance! Let joy be unconfined; /No sleep till morn, when Youth and Pleasure meet" (COHEN, 1960, p. 88). Os versos relatam o encontro entre "Juventude e Prazer", através da dança, da 
alegria e do propósito de "nada de sono até a manhã", referências que se aplicam, perfeitamente, ao verso "O ardor do vento a tua juventude", do poema de Sophia.

Parafraseando Lord Byron, "On with the dance!" - ou melhor, passemos ao próximo capítulo. 


\section{O QUARTO COMO PRISÃO.}

Começamos este capítulo com “Dia do Mar no Ar”, de Coral:

Dia do mar no ar, construído

Com sombras de cavalos e de plumas

Dia do mar no meu quarto - cubo

Onde os meus gestos sonâmbulos deslizam

Entre o animal e a flor como medusas.

Dia do mar no mar, dia alto

Onde os meus gestos são gaivotas que se perdem

Rolando sobre as ondas, sobre as nuvens. (ANDRESEN, 2001, p. 166)

No poema, o sujeito poético vê-se frente à dimensão infinita do mar, ao mesmo tempo em que se encontra limitado pelas medidas mais reduzidas do quarto, que assume a forma de um "cubo", figura geométrica completamente fechada em todos os seus lados.

Trata-se do "meu quarto" - mais uma vez, o emprego do possessivo não deixa dúvidas quanto à intimidade do espaço descrito. Se pensarmos no total fechamento da figura do cubo, temos, então, um eu completamente cercado ao redor de si mesmo, fechamento para o qual não vislumbra a perspectiva, nem de uma saída, nem de um alívio. Só lhe resta recorrer ao sonho, através dos "meus gestos sonâmbulos", num verso em que a repetição do mesmo possessivo reforça a ênfase colocada no sujeito, encapsulado dentro de seu quarto, enquanto, lá fora, exibe-se a imensidão do mar.

No sentido da profunda ligação entre o espaço do quarto e o sonho, vale recorrer a Michele Perrot, que nota a importância que o quarto começa a adquirir, a partir do século XIX, como espaço de privacidade: "Mas no século XIX o quarto é o espaço do sonho; ali se refaz o mundo". (PERROT, 1992, p. 321).

É freqüente, em Sophia, a recorrência ao sonho como uma espécie de salvação para uma situação irremediável, como a da própria morte. Vejamos "Apesar das Ruínas e da Morte", poema de abertura de Poesia I: 
Apesar das ruínas e da morte,

Onde sempre acabou cada ilusão,

A força dos meus sonhos é tão forte

Que de tudo renasce a exaltação

E nunca as minhas mãos ficam vazias. (ANDRESEN, 2001, p.15)

Aqui, os sonhos estão também explicitados como "meus", realçando o caráter de individualidade próprio dos sonhos. $\mathrm{O}$ eu poético reconhece nesses sonhos uma "força", "tão forte", a ponto de eles provocarem como que um renascimento, isto é, possibilitarem uma esperança de nova vida. A única estrofe do poema é toda construída através de uma sobreposição de opostos: de um lado, elementos negativos, sinônimos de queda e irrealidade, "ruínas", "morte" e "ilusão", contrapondo-se a dois fatores positivos, o qualificativo "forte" (que, numa enfática repetição, aparece no mesmo verso iniciado por "a força") e o substantivo "exaltação". O jogo de rimas entre o primeiro e o terceiro versos, e entre o segundo e o quarto, acaba destacando o quinto e último, este não rimado, "E nunca as minhas mãos ficam vazias", explicitando o poder dos sonhos, capazes de preencher a ausência e o vazio sentidos pelo sujeito.

Se nos dois poemas, "Dia do Mar no Ar" e "Apesar das Ruínas e da Morte”, os sonhos surgem como uma energia benéfica, capaz de favorecer uma possível ressurreição, encontramos em "O Jardim e a Noite", também de Poesia I, os sonhos retratados de maneira absolutamente contrária, mortos e "sepultados", no final da segunda estrofe:

Atravessei o jardim solitário e sem lua,

Correndo ao vento pelos caminhos fora,

Para tentar como outrora

Unir a minha alma à tua,

Ó grande noite solitária e sonhadora.

Entre os canteiros cercados de buxo,

Sorri à sombra tremendo de medo.

De joelhos na terra abri o repuxo,

$\mathrm{E}$ os meus gestos foram gestos de bruxedo. 
Foram os gestos dessa encantação,

Que devia acordar do seu inquieto sono

A terra negra dos canteiros

E os meus sonhos sepultados

Vivos e inteiros.

Mas sob o peso dos narcisos floridos

Calou-se a terra,

E sob o peso dos frutos ressequidos

Do presente,

calaram-se os meus sonhos perdidos.

Entre os canteiros cercados de buxo,

Enquanto subia e caía a água do repuxo,

Murmurei as palavras em que outrora

Para mim sempre existia

O gesto dum impulso.

Palavras que eu despi da sua literatura,

Para lhes dar a sua forma primitiva e pura,

De fórmulas de magia.

Docemente a sonhar entre a folhagem

A noite solitária e pura

Continuou distante e intangível

Sem me deixar penetrar no seu segredo.

E eu senti quebrar-se, cair desfeita,

A minha ânsia carregada de impossível,

Contra a sua harmonia perfeita.

Tomei nas minhas mãos a sombra escura

E embalei o silêncio nos meus ombros.

Tudo em minha volta estava vivo

Mas nada pôde acordar dos seus escombros 
O meu grande êxtase perdido.

Só o vento passou pesado e quente

E à sua volta todo o jardim cantou

E a água do tanque tremendo

Se maravilhou

Em círculos, longamente. (ANDRESEN, 2001, 20))

Além de começar por um verbo na primeira pessoa, detalhe que chama a atenção do leitor para a presença nítida do sujeito, já a partir do primeiro verso, o poema define um clima de ausências, de carências. O "jardim" está "solitário", sem ninguém para acompanhar o eu. A solidão aparece como mola propulsora da introspecção, caracterizando o tom intimista que envolve o poema. $\mathrm{Na}$ primeira estrofe, aliás, a solidão aparece repetida duas vezes, caracterizando tanto o jardim, quanto a noite, igualmente "solitária".

Ainda na primeira estrofe, o advérbio "outrora" indica um exercício de rememoração por parte do sujeito, que se recorda de um tempo antigo, provavelmente mais feliz, tempo no qual ele experimentou uma comunhão mais completa com a noite, que Sophia antropomorfiza, conferindo-lhe, inclusive, uma "alma". A união com a noite significa aquela aliança completa entre homem e universo, na qual a poeta insiste, como vimos observando, poema a poema.

A sexta estrofe, aliás, ressalta a "harmonia perfeita" da noite, conferindo-lhe qualidades quase divinas, em oposição à "ânsia carregada de impossível” sentida pelo eu poético. Vale observar a intensidade que a noite, ou a imagem dela, apresenta na poesia de Sophia. Essa constatação adquire maior força à medida que analisamos, em conjunto, os muitos poemas que se referem a esse espaço temporal, incluídos em seus livros.

Em "O Jardim e a Noite", a felicidade de "outrora" opõe-se a um "presente" tristemente caracterizado por seus "frutos ressequidos" e pelos "sonhos perdidos" do sujeito, que sinalizam um tempo sem esperança, onde os desejos não frutificam. Fica, desse modo, expressada a angústia íntima do eu poético, que vai procurar abrigo para o seu desconcerto num jardim, cenário simbolicamente importante, já que significa local de plenitude, de eternidade, como já observamos. 
"O Jardim e a Noite", na verdade, prenuncia alguns dos elementos também presentes em "Jardim Verde". É o caso das referências ao "buxo", ao "repuxo" e, também aos "narcisos". Quanto a "buxo" e "repuxo", percebemos, em "O Jardim e a Noite", uma hábil destreza estilística por parte de Sophia, que constrói uma onda sonora formada por vocábulos com som de /x/, que começa na segunda estrofe, quando "buxo" e "repuxo" aparecem pela primeira vez. Logo vem "bruxedo" e, mais adiante, na quarta estrofe, arrematando a onda em /x/, novamente "buxo" e "repuxo".

O leitor assíduo de poesia portuguesa não vai deixar passar desapercebida a coincidência destas rimas com as utilizadas por António Nobre, num trecho de seu poema inacabado "O Desejado", publicado postumamente (nesse trecho, inclusive, há a rápida descrição de um jardim):

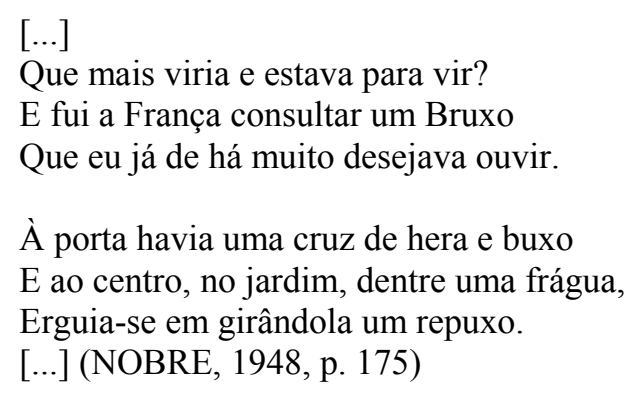

No poema de Nobre, uma terceira rima para "buxo" e "repuxo" introduz um "Bruxo", cuja menção sugere um personagem ligado à feitiçaria, portador de poderes sobrenaturais. Já no poema de Sophia, é justamente a repetição dos sons em /x/ que estabelecer uma relação quase mágica entre os vocábulos, aproximando "buxo" e "repuxo" de "bruxedo" e levando os versos como que a um clímax, quando, na quarta estrofe, o sujeito refere-se às "fórmulas de magia" como a "forma primitiva e pura" das palavras, lembrando o valor encantantório da palavra poética. Nesse sentido, Clara Rocha observa:

Na obra poética de Sophia, a emergência da palavra mágica é visível, antes de mais, ao nível dos termos saturados de desejo. Não é precisa uma leitura muito atenta para nos darmos conta da recorrência de certas palavras-chave que atestam esse investimento afectivo. É o caso de "praia", "mar", "areia", "espuma", "brilho", "jardim", "casa", "sonho", "noite", "instante", "deuses", "justiça", "harmonia”, "mãos", "coisas", "uno", "verdade”, etc. (ROCHA, 1994, p. 170)

É importante assinalar que, entre as "palavras-chave" de Sophia lembradas por Clara Rocha, estão algumas que assumem um significado especial com relação ao 
intimismo, como "jardim", "casa", "sonho" e "noite", três das quais, "jardim", "sonho" e "noite", assumem importância particular dentro de "O Jardim e a Noite", que agora analisamos. Além disso, dentro do conceito de "palavra mágica", empregado pela professora, é bastante significativa a quinta estrofe do poema, "Palavras que eu despi da sua literatura, /Para lhes dar a sua forma primitiva e pura, /De fórmulas de magia". Note-se que a "forma primitiva e pura" enfatiza dois momentos importantes do poema, o do verso "Para tentar como outrora", que se reporta a um tempo anterior, não contaminado pelas vicissitudes do presente, e o da "harmonia perfeita", da sexta estrofe, a sugerir a idealizada simbiose entre o homem e tudo que o rodeia.

Poema longo, repleto de imagens sugestivas, "O Jardim e a Noite" merece mais algumas observações. Trata-se, como lemos no primeiro verso, de uma noite "sem lua", indicando um negrume total, escuridão que também traduz o próprio estado do sujeito, tomado por seu desassossego íntimo. Por outro lado, como a lua é símbolo freqüente do sonho, das quimeras, do inalcançável, sua ausência pode significar, também, a falta dos próprios sonhos, reforçando o tom negativo do início do poema. Percebemos que a primeira estrofe termina com um clima realmente pessimista, pois a "noite [...] sonhadora" refere-se a um tempo já passado, agora inalcançável.

No entanto, talvez o que mais chame a atenção no poema sejam as contínuas referências à morte. Se, muitas vezes, em Sophia, o cenário do jardim é pretexto para a descrição de uma paisagem paradisíaca, transbordante de beleza ${ }^{14}$, em "O Jardim e a Noite", pouco, ou nada, transparece dessa beleza. Ao ligar o jardim à noite, o próprio título prenuncia um ambiente de decrepitude, finitude mesmo, no qual "a terra negra dos canteiros" (temos, aqui, uma possível associação com a imagem dos túmulos) acaba por sepultar (o termo é do poema), de forma definitiva, as expectativas do

\footnotetext{
${ }^{14}$ A propósito da beleza, nos jardins descritos nos poemas de Sophia, consultar, na Internet, as páginas do fotógrafo Joe Taruga, que apresenta uma coleção de 209 fotos coloridas inspiradas em versos da poeta. Por exemplo, a foto "O Jardim" (TARUGA, 2006), título também do quarto poema de Dia do Mar (ANDRESEN, 2001, 85), que traduz imagem da "clara tarde de cristal", na qual o sujeito espreita "os jardins do fundo do lago", através de uma sugestiva paisagem com um lago aparece em primeiro plano, refletindo a "indizível verdura" das árvores e a intensa luminosidade de um "Maio ácido e multicor" (a poeta, como já vimos, gosta de insistir nas estações do ano, com preferência pelos meses da primavera). No fundo da foto, de um lado, um daqueles tempiettos, típicos dos jardins clássicos europeus, confere ao cenário um certo ar, ao mesmo tempo, sagrado e nobre. A nobreza, ademais, vem enfatizada pelo palácio entrevisto entre as árvores - uma pena o palácio ser amarelo, pois, se fosse vermelho, poderia ser aquele de "O Palácio", poema de $O$ nome das coisas: "Era um dos palácios do Minotauro/- o da minha infância para mim o primeiro -/Teria sido construído no século passado (e pintado a vermelho)" (ANDRESEN, 1999, p. 187).
} 
sujeito. Para a sugestão da morte contribuem, também, a recorrência dos "narcisos" (flores que lembram a morte, como já vimos no Capítulo 1, em relação a "Jardim Verde") e a "sombra escura" da sétima estrofe, de certa forma uma visualização da própria morte.

A construção, um tanto lúgubre, antecipa-se, de modo angustiante, já na segunda estrofe, a mais longa do poema, na qual os "meus sonhos" (ou seja, os sonhos do próprio sujeito) acabam indo para o túmulo "vivos e inteiros", passando ao leitor toda a aflição de imaginar alguém sendo enterrado vivo.

Vejamos, agora, o que acontece na última estrofe, iniciada pelo verso "Só o vento passou pesado e quente". A referência ao vento, que na primeira estrofe já indicava ao sujeito as possibilidades de liberdade e alegria interior proporcionadas pelo contato direto com a natureza ("Correndo ao vento pelos caminhos fora"), vem, na última, se opor a todo o efeito negativo sugerido pelas contínuas alusões à morte. Aos adjetivos "distante e intangível”, que caracterizam “a noite”, contrapõe-se "o vento", "pesado e quente", mais próximo do sujeito, e capaz de fazer "todo o jardim" cantar, numa espécie de celebração destinada a comemorar que, apesar da "sombra escura", "Tudo em minha volta estava vivo".

Voltemos ao texto de Clara Rocha, citado acima. Logo depois de elencar as "palavras-chave" de Sophia, a professora menciona um trecho de Sophia (retirado daquele discurso A coisa mais antiga, no qual a poeta recorda "uma maçã enorme e vermelha" como "a coisa mais antiga de que me lembro", publicado como introdução ao volume I da Obra poética), salientando que "a própria autora confirma, aliás, a instrumentalidade mágica do dizer poético":

Sempre a poesia foi para mim a perseguição do real. Um poema foi sempre um círculo traçado à roda duma coisa, um círculo onde o pássaro do real fica preso. (ANDRESEN, 2001, p. 7)

É, justamente, sobre a prisão que falaremos agora. Isso porque, além de “O Jardim e a Noite" anular o poder dos sonhos (não é demais relembrar os versos "E sob o peso dos frutos ressequidos/ Do presente,/ calaram-se os meus sonhos perdidos", indicando, como vimos, uma profunda desilusão do eu com o tempo presente, tempo de secura, de aridez), temos, aqui, o cenário do jardim equivalendo, mesmo, a uma prisão. Com efeito, o sujeito aparece imóvel, calado, como calada está "a terra" e os 
"sonhos perdidos" do próprio sujeito. Seu único gesto, como num ritual, "De joelhos na terra", é o de abrir o repuxo. Ao mesmo tempo, acentuando sua imobilidade, constata que "Tudo em minha volta estava vivo" e coloca "vivo" em flagrante contraste com todas as imagens da morte, não fosse Sophia perita no realce dos opostos...

A imobilidade vem reencenada nos dois versos seguintes, "Mas nada pôde acordar dos seus escombros/ O meu grande êxtase perdido", nos quais os "escombros" indicam a queda, a decadência, a ruína, a morte. E a mesma imobilidade retorna, ainda, nos três últimos versos do poema ("a água do tanque tremendo/ Se maravilhou/ Em círculos, longamente”), que sugerem a metáfora da água movimentando-se em círculos, círculos viciosos a prender o sujeito em seu centro. Se pensarmos na presença dos "narcisos floridos", podemos encontrar, ainda, o sujeito refletindo-se nesse espelho de círculos viciosos, incapaz de encontrar uma saída para "O meu grande êxtase perdido", sobretudo porque se trata de um "tanque", espaço fechado, restrito, da mesma forma que o "cubo" do poema anterior.

A segunda observação diz respeito ao círculo, no trecho do discurso de Sophia, círculo que esse que repercute naquele "círculo do ar e do mar" do poema em prosa "As Grutas", que, como salientamos no primeiro capítulo desta dissertação, corresponde à idéia de algo completamente fechado em torno de si mesmo. No texto do discurso, ao precisar o "círculo onde o pássaro do real fica preso", Sophia enfatiza a imagem do círculo como metáfora da prisão.

Ainda temos algo a dizer, a respeito de "O Jardim e a Noite". Sobre os narcisos, por exemplo, que no poema aparecem pesados: "sob o peso dos narcisos floridos/ Calou-se a terra". Nos versos imediatamente seguintes, mais uma carga, um fardo, “o peso dos frutos ressequidos/ Do presente". Na verdade, vergado sob o peso de sua própria solidão está o sujeito poético. Enquanto a imagem da terra calada vem reiterar a idéia de sepultamento, os "frutos ressequidos" definem, como já dissemos, um "presente" árido e inóspito. Ou seja, um tempo estéril, infrutífero, acompanhando o estado de um eu desapontado com o mundo. O "outrora", na estrofe seguinte, evocado pela "água do repuxo" (é nítida a sugestão de uma fonte de vida) reporta-se a um tempo anterior, certamente mais tranqüilo, no qual o sujeito ainda podia se sentir mais livre e se valer do "gesto dum impulso", diferente deste "presente" atormentado, marcado pelo silêncio dos "meus sonhos perdidos". 
Quanto ao círculo, trata-se de um tema recorrente na poesia de Sophia. Com efeito, Livro sexto traz um poema intitulado, justamente, "Círculo". Nele, Sophia estabelece com rigor, podemos dizer, geométrico, a idéia do "círculo fechado", um círculo, mais uma vez, encarado como prisão, sem nenhuma hipótese de saída, a não ser a inevitável morte:

Num círculo se move

Num círculo fechado

Sua morte o envolve

Como uma borboleta

Seus verdugos o cercam

Como quem cerca o toiro

Em sua volta não vê

Nenhuma porta aberta

Grandes panos de sangue

Sobre os olhos lhe estendem

A sua hora estava

- Como se diz - marcada

Pegador não houve

Nem pega de caras

$\mathrm{E}$ as portas estavam

Sobre o grito fechadas (ANDRESEN, 1991, p. 175)

O leitor consegue perceber, nítida, a imagem de alguém acossado, num círculo-prisão tão hermético e envolvente (este último termo é sugerido pelo próprio poema), como o casulo no qual está encerrada a larva de uma borboleta. Percebe-se que "morte" e "borboleta" aparecem na mesma estrofe, sublinhando a metamorfose 
pela qual passa esse inseto, já que, como lembra Hans Biedermann, a borboleta "é um dos animais que aludem à ressurreição" (BIEDERMANN, 1993, p. 254). O mesmo Biedermann, ao se referir à "capacidade de mudar" da borboleta, vê nisso um exemplo da "transitoriedade da felicidade" (BIEDERMANN, 1993, p. 57), citando, a seguir, o livro sobre a interpretação dos sonhos de Ernst Aeppli:

"A maravilha desse fenômeno de metamorfose que se origina e se desenvolve sem intervenção externa, conduzindo o animal da condição de lagarta à de crisálida e depois à de borboleta, tem tocado profundamente o homem, que se vê assim movido a refletir a respeito de sua própria transformação espiritual, imbuído da esperança de poder ascender algum dia da prisão terrena à liberdade da luz eterna “ (AEPPLI, 1943, apud BIEDERMANN, 1993, p. 57).

Verso a verso, o sujeito poético de "Círculo", mencionado sempre na terceira pessoa, vai sofrendo cada vez mais. Trata-se de um sofrimento intenso, do qual ele não consegue escapar. Nesse sentido, a sexta estrofe é bem clara: "A sua hora estava/ - como se diz - marcada”. Na descrição dessa agonia, surgem passagens que lembram as cenas bíblicas da Via Sacra, como a figura dos "verdugos"15, ou os "panos de sangue", que podem remeter ao pano que a personagem Verônica estendeu "Sobre os olhos" de Cristo.

Acossado e perseguido, ao protagonista do poema não resta saída alguma, destino cuja irreversibilidade é reiterada duas vezes, na quarta estrofe ("Em sua volta não vê/ Nenhuma porta aberta") e na última ("E as portas estavam/ Sobre o grito fechadas"). Notamos, mais uma vez, a importância das portas como elemento típico da escrita intimista ${ }^{16}$. Aqui, por estarem absolutamente "fechadas", apontam para o estado de absoluta incomunicabilidade ao qual o sujeito chegou, incapacitado de se comunicar com o mundo externo, daí sua insatisfação.

\footnotetext{
${ }^{15}$ Aurélio Buarque de Holanda Ferreira ensina que o termo "verdugo" origina-se numa palavra latina, cujo significado é o de "vara verde usada como açoite". A explicação torna o sentido de "verdugo" ainda mais cruel.

16 A porta é também um elemento significativo para a linguagem cinematográfica. Foi o que notou o crítico e diretor Michel Cournot, em relação ao filme Baltazar, de Robert Bresson, segundo Chevalier e Gheerbrant: “[...] as criaturas de Baltazar passam a maior parte de seu tempo a abrir e fechar portas, a passar e tornar a passar por portas. Basta ser um pouquinho sensível à transcendência para ver que uma porta não é simplesmente uma abertura feita em uma parede ou um conjunto de peças de madeira capazes de girar nos encaixes. Dependendo de se ela estiver aberta, fechada, trancada a chave, batendo, a porta é, sem modificar em nada a sua natureza, presença ou ausência, apelo ou defesa, perspectiva ou plano cego, inocência ou erro. [...] No estado de espírito bressoniano, universal se diz ecumênico: não há imagem mais ecumênica da vida que a de uma porta que é aberta e outra vez fechada; a porta permite também significar sem degradar" (Le Nouvel Observarvateur, 1966, n. 80, p. 40) (CHEVALIER E GHEERBRANT, 1999, p. 737).
} 
Como lembram Chevalier e Gheerbrant, "a porta simboliza o local de passagem entre dois estados, entre dois mundos, entre o conhecido e o desconhecido, a luz e as trevas, o tesouro e a pobreza extrema" (CHEVALIER E GHEERBRANT, 1999, p. 734). Estando fechada, ou melhor, "fechadas", como é o caso de "Círculo", impedem o sujeito o acesso ao mundo do conhecimento, da luz e das riquezas (estas, assim somos levados a entender, espirituais), restringindo-o a um estado, profundamente negativo, de trevas e de absoluta pobreza.

Voltaremos a falar de portas mais adiante, ainda neste capítulo, ao analisar outros dois poemas de Sophia, nos quais ela se refere, em sentido inverso, às "portas (...),/ Abertas para os caminhos" (em "Assassinato de Simonetta Vespucci”) e às "mil portas abertas" (em "Portas da Vila").

Se o destino do sujeito de "Círculo" afigura-se irreversível, mostra-se, também, um tanto injusto, pois "pegador não houve/ nem pega de caras", menção à inexistência daquela caçada que daria ao perseguido uma oportunidade de defesa, lembrando os versos do poema "Arte Poética", já analisado no capítulo referente ao silêncio, que traz um eu "atent[o] para a caçada no quarto penumbroso" (ANDRESEN, 2004).

De certa forma, a metáfora do caçador e da caçada permanece como uma espécie de epitáfio à própria obra de Sophia, segundo este texto lido pela escritora portuguesa Maria Velho da Costa, durante a missa em homenagem à poeta, logo após o seu falecimento, em julho de 2004: “[...] Mas acho que foi Sophia quem escreveu o seu próprio epitáfio nesta "Ode à Maneira de Horácio" [de O búzio de cós e outros poemas]. Fiquemos com a sua voz, o claro sopro que é o seu legado" (VELHO DA COSTA, 2006):

Feliz aquela que efabulou o romance

Depois de o ter vivido

A que lavrou a terra e construiu a casa

Mas fiel ao canto estridente das sereias

Amou a errância, o caçador e a caçada

E sob o fulgor da noite constelada,

À beira da tenda, partilhou o vinho e a vida (ANDRESEN, 2004) 
O poema de Sophia lido por Velho da Costa constitui uma celebração da própria vida, citando, de maneira quase ritual, as atividades fundamentais do homem (o arar da terra, a construção da casa, a partilha do vinho), mas não se esquecendo de salientar a importância dos mitos (o "canto estridente das sereias") e da própria criação literária ("Feliz daquela que enfabulou o romance”). A criação literária, aliás, aparece como indissolúvel da própria vida, como deixa claro o segundo verso, "Depois de o ter vivido". Sophia, enfim, mostra-se, como sempre, fiel ao seu próprio léxico poético, mencionando, de maneira bastante expressiva, o brilho das estrelas ("sob o fulgor da noite constelada"), que traz para o poema a vastidão eterna do espaço estelar, em significativo contraponto aos elementos humanos (o trabalho na terra, a "casa" e, como veremos a seguir, a "caçada") e míticos (as "sereias") do poema.

Já a passagem "Amou a errância" recorda um tempo primitivo, quando o homem era mais nômade e mais ligado à terra e ao ciclo da natureza. Nesse sentido temos, também, "o caçador e a caçada", evocando uma atividade que, em época longínqua, era fundamental à própria sobrevivência humana.

Mas, voltemos a "O Círculo", poema no qual a descrição de uma vítima que é caçada sem poder se defender ganha cores mais trágicas na terceira estrofe, "Seus verdugos o cercam/ Como quem cerca o toiro". Há aqui, uma enfática referência à crueldade injusta (e de certa forma desumana, embora dirigida a um animal) das touradas. Nessa perspectiva, os "Grandes panos de sangue", poderiam, também, se referir à capa vermelha com a qual os toureiros atiçam o touro.

Se Cristo é presença freqüente na poesia de Sophia, poucas vezes seu sofrimento é associado de maneira tão veemente à angústia do sujeito, como no caso do protagonista deste poema. Não comparece, certo, o cenário do quarto. Mas o recurso à figura geométrica do círculo é equivalente, em termos de clausura, à daquele cubo de "Dia do Mar no Ar", retratando, assim, o tormento de um eu incapaz de encontrar remédio e alívio para sua dor íntima. Ao lembrar a "Ode à Maneira de Horácio", a escritora Velho da Costa parece, com o perdão da metáfora, ter colocado o dedo exatamente no centro da ferida, pois esse é um poema no qual Sophia claramente busca refúgio num tempo antigo e imemorial, para tentar encontrar uma resposta à perplexidade e fragmentação do homem contemporâneo.

Interessante notar que Sophia não deixou clara esta perplexidade apenas em seus poemas, como também através de sua palavra fixada em entrevistas. Como nesta 
resposta ao escritor e diplomata brasileiro João Almino (1950), para o jornal Folha de S. Paulo, em 1999, logo após ela ter recebido o Prêmio Camões:

Pergunta de João Almino: - Então?! Uma jovem que testemunhou muito do século 20 e que assistirá a esse momento simbólico da passagem do milênio. Pergunto-lhe: como encara o futuro da humanidade? Acha que ela está seguindo um bom caminho?

Resposta de Sophia: - Eu tenho medo de que seja a idade de chumbo, não? Porque está muito sombrio. Quando se vê a guerra do Kosovo, sem as regras de moral, em que se perde até aquilo que os romanos tinham, que era o respeito pelo direito das gentes, dos povos - está claro que eles não tinham sempre, mas em si o direito instituíram -, e esse enorme poder concentrado num único país, que é muito mais próspero que os outros e que é capaz de fazer uma guerra sem saber por quê, sem preparação, sem pensamento, sem nada. (ALMINO, 1999)

Retornando à analise de "Dia do Mar no Ar", poema que deu início a este capítulo, percebemos, através da leitura do poema, como Sophia explora o jogo de tensões surgido do choque entre um eu debruçado sobre si mesmo, cercado pelos limites rigidamente geométricos de seu quarto, e a difícil apreensão do universo que o cerca. $\mathrm{O}$ choque é realçado por imagens marcantes, quer de animais (da terra, no caso dos "cavalos", do ar, como as "gaivotas", ou do mar, as "medusas"), quer de componentes de alta voltagem simbólica (as "plumas" e as "flores").

Já no segundo verso, ao mencionar as "sombras de cavalos e de plumas", a poeta, como é seu costume, explora as divergências entre os contrários, comparando a concretude terrestre da figura do cavalo, imagem de um animal veloz e nobre, “personificação simbólica da força e vitalidade" (BIEDERMANN, 1993, p. 78), à imponderabilidade quase aérea da pluma, figuração exemplar da leveza, daquilo que não domina seu próprio movimento. A mesma pluma que, como indicam Chevalier e Gheerbrant, simboliza "um poder aéreo, liberado dos pesos deste mundo" (CHEVALIER \& GHEERBRANT, 1999, p. 725).

Vale mencionar a rica conotação do cavalo na mitologia grega, segundo RobertJacques Thibaud:

[O cavalo é considerado] atributo de Posêidon, de quem se dizia ser o pai dos cavalos selvagens; no entanto, foi Atenas (a razão) quem ofereceu os freios aos homens, para que estes pudessem dominá-los. [...] [Devido à sua ligação com] Posêidon, o garanhão e o cavalo selvagem ilustram o aspecto instintivo, generoso e brutal [desse] deus, apelidado de $O$ Destruidor da Terra. Sempre símbolo do poder e da energia, o cavalo deve ser domado pela sabedoria e pela razão (as rédeas e os freios de Atenas). Símbolo das possibilidades humanas, o cavalo transporta o princípio da transformação (o raio [de Zeus]) 
e faz nascer sob seus cascos a inspiração que habita as Musas e os poetas (THIBAUD, 1996, p. 147-148, trad. minha).

Ao contrapor a leveza etérea das "plumas" à nitidez concreta e forte dos “cavalos", Sophia salienta, mais uma vez, o caráter transitório da passagem do homem pela terra. Na verdade, o poema retrata o homem como um ser incapaz de ações realmente efetivas, pois seus atos nada mais são que "gestos sonâmbulos", ou, como quer a última estrofe, "gestos" "que se perdem", seja na altura, distante da realidade terrena, das "nuvens" e das "gaivotas", seja na espuma inconsistente das "ondas".

Quanto às medusas, além de toda a carga simbólica desse animal celenterado, cuja origem, explicada pela mitologia grega, já comentamos no capítulo sobre o silêncio, vale lembrar que a sua aparência física é um tanto ambígua, pois trata-se de um animal que se assemelha a uma planta, detalhe que o próprio poema evidencia, através do verso "entre o animal e a flor como medusas".

Enquanto animal marinho, as medusas receberam esse nome por lembrarem, fisicamente, a cabeça com cabelos de serpentes da temível personagem mitológica Górgona Medusa. Ao citá-las, Sophia carrega o poema com aquela ambigüidade tradicionalmente associada à própria Górgona, cujo "fascínio", segundo Camille Dumoulié, "é provocado por uma mistura de beleza e horror": "na Antigüidade, [a cabeça de Medusa] tinha a função de máscara apotropaica, uma espécie de talismã que salva e mata ao mesmo tempo. Símbolo mesmo da ambigüidade, a cabeça de Medusa é também uma das mais arcaicas figuras míticas [...]. Tudo leva a crer, portanto, que ela seja mais uma representação do sagrado em seu aspecto mais significativo”. (DUMOULIÉ, 1997, p. 620, grifo da autora).

Dumoulié insiste em salientar o caráter ambíguo das medusas, ao lembrar o motivo da denominação do animal: "Essa ambigüidade irredutível encontra-se na classificação do animal chamado medusa, que deve seu nome à semelhança que guarda com a cabeça de Medusa (cf. Apolinaire, Bestiaire [Bestiário], 192017), mas integra-se à categoria dos acéfalos" (DUMOULIÉ, 1997, p. 624).

No entanto, ainda segundo Dumoulié, as qualidades de espelho e máscara presentes, simultaneamente, na cabeça de Medusa, podem implicar, também, numa associação com a ameaça nuclear, sempre possível no horizonte do homem

\footnotetext{
${ }^{17}$ Este é o poema "La Méduse", de Guillaume Apollinaire: "Méduses, malheureuses têtes/ Aux chevelures violettes/ Vous vous plaisez dans les tempêtes,/ Et je m'y plais comme vous faites." (APOLLINAIRE, 2007)
} 
contemporâneo: “A cabeça de Medusa é espelho e máscara. [...] Assim, ela representa bem a imagem da morte para aquele que a percebe. Todos esses temas - violência sacralizada, morte petrificadora - estão expostos na obra de Walter Krüger, consagrada ao perigo nuclear: Das Gorgonenhaupt (A cabeça de Górgona, Berlim, 1972) (DUMOULIÉ, 1997, p. 622).

O sujeito poético de "Dia do Mar no Ar", encerrado e isolado em seu quarto, comparado a um cubo hermeticamente fechado, encontra-se engaiolado, fechado sobre si mesmo e privado, inclusive, de seus movimentos. Petrificado, podemos acrescentar, pois os animais marinhos medusas levam-nos a pensar nos infelizes que, segundo a mitologia grega, morriam transformados em pedra, ao contemplar o rosto da Górgona Medusa. Assim, no cenário limitado, restrito, de seu quarto-cubo, só restam ao sujeito os "gestos sonâmbulos": é como se ele não estivesse vivendo, mas sonhando - portanto, afastado da realidade, incapaz de controlar suas próprias atitudes.

$\mathrm{Na}$ estrofe final, a comparação dos gestos ao vôo das gaivotas, denota um completo afastamento da realidade imediata, da terra, de tudo o que está aqui embaixo. Vale lembrar que a gaivota configura, também, uma imagem da solidão, pois é uma ave que se encontra, constantemente, só. De qualquer maneira, Sophia parece ter demonstrado por essa ave uma predileção especial, tanto é que a encontramos em, pelo menos, outro quatro poemas, dois de Coral ("Barco" e "A Praia Lisa"), um de No tempo dividido (“Tarde") e um de Dual (em "Odysseus - Persona", uma das divisões do longo, para os padrões de Sophia, poema "Em Hydra, Evocando Fernando Pessoa").

A presença da gaivota em todos esses poemas será analisada em detalhe, pois, como veremos, esse pássaro, na obra poética de Sophia, associa-se, não só momentos de solidão, mas torna-se capaz de detonar, também, passagens ligadas à morte, auxiliando a compor o clima de intimismo que vimos assinalando nos poemas da autora.

Comecemos por "A Praia Lisa". Nele, as gaivotas comparecem como um evidente símbolo da solidão, através do verso "Num gesto solitário passam as gaivotas", que fecha a primeira estrofe. Reproduzimos a íntegra do poema:

A praia lisa de Eurydice morta

As ondas arqueadas como cisnes 
As espumas do mar escorrem sobre um vidro

Num gesto solitário passam as gaivotas.

\author{
Endymion ressurge dos destroços \\ Os pinheiros gemem na duna deserta \\ O lírio das areias desabrocha \\ O vento dobra os ramos da floresta. (ANDRESEN, 2001, p. 237)
}

Além da solidão, corroborada pela "duna deserta" da segunda estrofe, notamos também a presença incisiva da morte, através dos personagens mitológicos Eurídice e Endimion, ambos grafados por Sophia à maneira tradicional, como é seu costume. Eurídice e Endimion são protagonistas de duas das mais famosas narrativas que ligam o amor à morte: depois que Eurídice morre, seu amado Orfeu consegue descer aos infernos para tentar recuperá-la para o mundo dos vivos, o que, afinal, não consegue; quanto ao belo mortal Endimion, sua história conta como lhe foi concedido um sono eterno, a pedido da deusa Selene, que por ele apaixonada, desejou que ele não morresse nunca.

Em "A Praia Lisa" a morte insinua-se através de outros elementos, como os "destroços" do primeiro verso da segunda estrofe, a sugerir uma desolada paisagem de ruínas, ou restos de um naufrágio, pois se trata de uma praia. Essa praia acaba descrita à semelhança de um cemitério, seja através dos "pinheiros", tipo de árvore muito utilizada em cemitérios, seja pelo "lírio", flor que, como já vimos, pode ser considerada como símbolo da morte, seja, enfim, pela utilização do verbo "dobra" no último verso do poema, que pode remeter ao dobrar dos sinos anunciando um evento fúnebre.

"Barco", incluído a seguir, traz, ao lado do próprio "barco", vários dos componentes ligados ao intimismo:

Margens inertes abrem os seus braços

Um grande barco no silêncio parte.

Altas gaivotas nos ângulos a pique,

Recém-nascidas à luz, perfeita a morte.

Um grande barco parte abandonando 
As colunas de um cais ausente e branco.

E o seu rosto busca-se emergindo

Do corpo sem cabeça da cidade.

Um grande barco desligado parte

Esculpindo de frente o vento norte.

Perfeito azul do mar, perfeita a morte

Formas claras e nítidas de espanto (ANDRESEN, 2001, p. 236)

Notamos que as gaivotas encontram-se "altas", numa posição aérea que denota seu afastamento da realidade terrena. E mais, estão ligadas diretamente aos "ângulos", essa figuração de um obstáculo, como que a alertar para um perigo iminente.

A "morte", duas vezes caracterizada como "perfeita", é, talvez, o principal destaque do poema, ecoando através de vários dos vocábulos e expressões a ela associados, direta ou indiretamente: "inertes", "parte" (esses dois apresentam um certo eco sonoro com "morte"), "a pique", "abandonado", "ausente", “corpo sem cabeça", "desligado". Não temos, aqui, a presença de um quarto, ambiente que escolhemos para caracterizar espacialmente o intimismo de Sophia, nem a de uma casa. No entanto, é importante lembrar que o "barco" carrega uma imagem e um significado poéticos bastante semelhantes ao da casa. Este "barco", aliás, é nomeado três vezes: na primeira, associado ao "silêncio", importante elemento da poética intimista, tema por nós abordado no capítulo inicial desta dissertação; na segunda, descrito como "abandonado", adjetivo que, se fosse aplicado a um possível sujeito (este não é nomeado no poema), caracterizaria alguém solitário, em estado de desamparo e, portanto, passível de se voltar completamente para dentro de sua própria angústia, numa típica operação intimista; na terceira, enfim, o "barco" apresenta-se "desligado", ou seja separado do mundo e da realidade terrestre, reforçando o clima um tanto fúnebre do poema.

A notar, também, a perfeição do "mar", aqui, como em 'Dia do Mar no Ar" e em outros poemas de Sophia, a sugerir uma possibilidade de escape, graças, não somente à sua dimensão infinita, mas também possibilitando uma hipótese de salvação, pois, lembra Biedermann, “a água corrente e sobretudo a água agitada do mar lavariam qualquer magia negativa” (BIEDERMANN, 1993, p. 17). Mas, em "Barco", a sugestão, tanto de escape, como de salvação, parece ser impossível de ser 
concretizada, uma vez que ao "mar" logo se contrapõe a "morte", esta, como já notamos, por duas vezes enfaticamente caracterizada como "perfeita".

Temos, ainda, duas observações sobre "Barco". A primeira, sobre as "gaivotas", que surgem "recém-nascidas", num momento poeticamente expressivo, inclusive pelo contraste em relação à "morte". A segunda, relativa ao no último verso, no qual encontramos novamente aquele "espanto", mencionado em alguns dos poemas vistos no primeiro capítulo. Para Sophia, essa atitude tão humana de se espantar frente ao desconhecido, frente àquilo a que não estamos acostumados, parece mais uma forma de maravilhamento, de deslumbramento (daí as "formas nítidas e claras"), frente a todas as coisas deste mundo - entre as quais podemos incluir a própria morte, exatamente por esse motivo possível de ser definida como "perfeita".

A seguir, falaremos de "Odysseus - Persona", subtítulo que identifica um trecho de um poema mais extenso, "Em Hydra, Evocando Fernando Pessoa", homenagem de Sophia ao mais importante poeta português do século XX. Desse trecho, reproduzimos apenas uma estrofe, cujo último verso fala das "gaivotas", comparadas às flores, numa construção de grande beleza poética:

(...)

Imagino que viajasses neste barco

Alheio ao rumor secundário dos turistas

Atento à rápida alegria dos golfinhos

Por entre o desdobrado azul dos arquipélago

Estendido à proa sob o voo incrível

Das gaivotas que o sol espalha impetuosas pétalas

(...) (ANDRESEN, 1999, p. 145)

Comentar esses versos implicaria em referências a Pessoa, a quem são dirigidos. Para não nos alongarmos demais, fugindo ao escopo principal dessa dissertação, preferimos não enveredar por esse caminho, salientando, apenas, a perspectiva aérea das "gaivotas" (e seu "voo incrível”), em oposição ao menos importante bulício terrestre, representado pelo "rumor secundário dos turistas" (grifo meu).

Os dois últimos poemas (na verdade, um poema inteiro e um trecho de outro) que analisamos, incluem o "barco", pois as gaivotas acompanhando uma embarcação 
compõem uma imagem muito recorrente. Dela não escapou Camilo Pessanha e, como vimos assinalando certos ecos da poesia dele na de Sophia, citamos o segundo e o terceiro versos do poema de Clepsydra que começa por "Nesgas agudas do areal": "E gaivotas que voaes ao redor do navio/ Tomae o meu cérebro mole" (PESSANHA, 1994, P. 127).

Chegamos à "Tarde", o derradeiro poema do grupo que menciona a "gaivota". Trata-se de uma composição curta, com apenas uma estrofe de dois versos, sugerindo um diálogo, talvez amoroso:

O que eu queria dizer-te nesta tarde

Nada tem de comum com as gaivotas. (ANDRESEN, 1991, p. 24)

A economia de palavras, tão prezada por Sophia, não impede que ela crie uma atmosfera sugestiva, levando o leitor a imaginar uma possível despedida (que acompanharia o clima, podemos imaginar, crepuscular da "tarde", período final do dia), além de uma certa dificuldade encontrada pelo sujeito, ao tentar se comunicar com a provável pessoa amada (pois o tempo verbal de "queria dizer-te" expressa mais um desejo, do que a efetiva realização desse desejo). A vontade de dizer alguma coisa à pessoa amada "Nada tem em comum com as gaivotas", ou seja, não teria nada de aéreo, inconseqüente, sendo, pelo contrário algo de muito sério, ligado à realidade, ao racional.

Terminado este intervalo dedicado às gaivotas, voltamos ao poema que o originou, "Dia do Mar no Ar". Estávamos dizendo que, em sua estrofe final, a comparação dos gestos do sujeito ao vôo das gaivotas aponta na direção de um total distanciamento da realidade terrena. Pois esse afastamento, somado à metáfora das ondas (que trazem para o poema não só a precariedade da espuma das “ondas", mas também o perigo que esta força da natureza representa, pois quem está "rolando sobre as ondas" está, também, à beira de um naufrágio evidente) e ao inalcançável das nuvens, acaba evidenciando a diminuta dimensão mortal do sujeito, frente à majestosa eternidade da natureza. Lembremos que as nuvens, como salienta Cirlot, "pertencem ao céu, elas ocultam a morada da divindade" (CIRLOT,1984, p. 492). Bachellard, por sua vez, dedica todo um capítulo de seu livro $O$ ar e o sonho às nuvens, salientando: “As nuvens contam-se entre os objetos poéticos mais oníricos. São os objetos de um onirismo do pleno dia. Determinam devaneios fáceis e efêmeros. Por um instante 
estamos nas nuvens e, ao regressarmos à terra, somos docemente ridicularizados pelos homens positivos" (BACHELARD, 1990, p. 189).

Essas palavras de Bachelard parecem que se destinam especificamente a "Dia do Mar no Ar”, poema no qual o pleno dia já vem, de certa maneira, expresso a partir do título. Por outro lado, os "gestos sonâmbulos" estão diretamente ligados ao onirismo e aos devaneios expressos por Bachelard, levando o leitor a realmente imaginar o sujeito num estado irreal, nas nuvens, ou, mais exatamente, como escreveu Sophia, "sobre as nuvens".

Em “Dia do Mar no Ar" há a destacar, também, a afiada habilidade poética de Sophia, ao alternar itens concretos e fluídos, fortes e fracos, baixos e altos, terrestres e aéreos, introduzindo, no poema, uma espécie de vaivém entre a realidade e a fantasia, ocultando e revelando, como num jogo de esconde-esconde, ora elementos positivos, significando a esperança de redenção (poderíamos, inclusive, pensar em Pégaso, o cavalo alado que a mitologia grega narra ter nascido, também, do sangue da Górgona Medusa), ora negativos, como a prisão do quarto-cubo ou a ameaça de naufrágio sugerida pelas ondas.

Temos uma razão especial para grifar aéreos, pois é exatamente sobre o desenvolvimento do conceito de aéreo que Bachelard desenvolve sua obra $O$ ar e os sonhos:

[...] A sublimação aérea é a sublimação discursiva mais típica, aquelas cujos graus são mais manifestos e mais regulares. Ela se prolonga por uma sublimação dialética fácil, muito fácil. Parece que o ser voante ultrapassa a própria atmosfera em que voa; que um éter se oferece sempre para transcender o ar; que um absoluto completa a consciência de nossa liberdade. Será preciso ressaltar, como efeito, no reino da imaginação o epíteto que mais próximo se encontra do substantivo ar é o epíteto livre? O ar natural é o ar livre. (BACHELARD, 1990, p. 8, grifos do autor)

Sob a perspectiva de Bachelard, o que temos em "Dia do Mar no Ar", portanto, é o embate entre um sujeito consciente do drama íntimo de estar preso aos referenciais de sua vida terrena, representada pelos limites geométricos de seu quartocubo, mas tentado a se libertar na direção simbolizada pelo "alto", embalado pela leveza aérea das "plumas", desejando se perder (termo do poema) "sobre as nuvens", tal como as "gaivotas", ave à qual Sophia emprestou grande importância poética, como assinalamos acima. Lembramos que a gaivota, além de ser ave (e, portanto, diretamente ligada ao elemento ar), é, sobretudo, uma ave marítima, que vive no litoral e do mar retira seu alimento, sendo, assim, imageticamente ligada ao "mar", 
componente de realce no poema "Dia do mar no ar" e cenário, como já apontamos, constantemente utilizado por Sophia em sua obra poética, em seus contos e em suas histórias para crianças.

Ainda quanto ao mar, não fíca difícil, para o leitor de "Dia do mar no ar", visualizar, na construção do poema em vaivém, conforme assinalamos alguns parágrafos acima, o próprio movimento das marés, avançando ou recuando sobre a praia. A sugestão ao movimento do mar fica reforçada pelas "ondas" do último verso e podemos entender a referência à contínua sucessão das marés como mais uma metáfora do ciclo eterno da natureza. Notamos que a expressão "Dia do mar" marca o início de cada uma das três estrofes, sendo que, na última, o termo "mar" vem enfaticamente repetido, "Dia do mar no mar".

Vale lembrar o que dizem Chevalier e Gheerbrant a respeito do mar:

[O mar representa o] símbolo da dinâmica da vida. Tudo sai do mar e tudo retorna a ele: lugar dos nascimentos, das transformações e dos renascimentos. Águas em movimento, o mar simboliza um estado transitório entre as possibilidades ainda informes [e] as realidades configuradas, uma situação de ambivalência, que é de incerteza, de dúvida, de indecisão, e que pode se concluir bem ou mal. Vem daí que o mar é ao mesmo tempo a imagem da vida e a imagem da morte. (CHEVALIER E GHEERBRANT, 1999, p. 592).

Se o mar pode representar uma situação de ambivalência, como sugerem os dois autores, essa bipolaridade, no poema, aparece reformada pela imagem ambígua das medusas. Na verdade, como já apontamos, todo o poema "Dia do Mar no Ar" constrói-se através de uma sucessão de contrastes, entre definido e indefinido, entre real e irreal. Assim, fica ressaltada a palavra mais importante de todo o poema, o sólido e maciço "cubo" - o qual, de qualquer modo já estava destacado pela utilização do travessão que o isola e, desse modo, enfatiza o sentimento de solidão do eu insulado em seu quarto-cubo.

Na última estrofe, o verso "Onde os meus gestos são gaivotas que se perdem", finaliza pelo verbo perder, o qual pode apontar para o estado no qual o sujeito vê-se a si mesmo, desorientado, perdido, entre a realidade e os sonhos, entre a presença nítida (e convidativa) do mar e a distância aérea das nuvens, incapaz de definir um rumo que o conduzisse para além dos limites rígidos de seu quarto-cubo-prisão. Tal indecisão vem sublinhada pelos "gestos sonâmbulos" que "deslizam" (ou seja, escorregam, tropeçam, sem atingir uma finalidade definida) e lembram a ambigüidade típica das medusas (animal ou planta?). 
Passemos a "Assassinato de Simonetta Vespucci", poema também de Coral, como "Dia do Mar no Ar", e que apresenta, sob outro prisma, o aspecto geométrico e aprisionador dos quartos:

\section{Homens}

No perfil dos quartos

Nos ângulos mortais da sombra com a luz.

Vê como as espadas nascem evidentes

Sem que ninguém as erguesse - de repente.

Vê como os gestos se esculpem

Em geometrias exactas do destino.

Vê como os homens se tornam animais

E como os animais se tornam anjos

E um só irrompe e faz um lírio de si mesmo.

Vê como pairam longamente os olhos

Cheios de liquidez, cheios de mágoa

De uma mulher nos seus cabelos estrangulada.

E todo o quarto jaz abandonado

Cheio de horror e cheio de desordem.

$\mathrm{E}$ as portas ficam abertas,

Abertas para os caminhos

Por onde os homens fogem,

No silêncio agudo dos espaços,

Nos ângulos mortais da sombra com a luz. (ANDRESEN, 2001, p. 194)

A primeira palavra enunciada, "Homens", já localiza o poema no plano terrestre do cosmos, abrindo espaço para a caracterização de sentimentos humanos. Já na primeira estrofe, o vocabulário utilizado, incluindo expressões como "perfil dos 
quartos" ou "ângulos mortais" (esta, repetida uma segunda vez, no verso final do poema) e, mais à frente, "geometrias exactas" e "silêncio agudo", descreve um ambiente no qual predominam as arestas, os obstáculos, salientando os perigos e embates enfrentados pelo homem.

É também no livro Coral que encontramos "Poema", poema curto, de apenas três estrofes, o qual, embora se refira, metapoeticamente, ao formato gráfico do próprio poema, também apresenta, entre seus poucos vocábulos, os mesmos elementos, digamos, geométricos de "Assassinato de Simonetta Vespucci". A seguir, "Poema":

Poema de geometria e de silêncio

Ângulos agudos e lisos

Entre duas linhas vive o branco. (ANDRESEN, 2001, p. 235)

Em "Poema", o único verbo, "vive", refere-se, não às palavras, mas ao espaço em branco que sobrevive, em realce, como que respirando, entre dois versos. Assim, o não-dito torna-se mais importante que o dito e o importante, na verdade, seria o "silêncio", este, então, mais válido que as palavras, ou que os versos do poema. Estaria Sophia, aqui, referindo-se à inutilidade prática da poesia? Ou trata-se de uma menção à página em branco, referida em outros de seus poemas (por exemplo, na estrofe "Como página em branco/ Onde o poema emerge"18, de "Revolução", poema de "O nome das coisas" escrito logo após a revolução de 25 de abril de 1974, que livrou Portugal da ditadura salazarista), lembrança do próprio ofício de escrever o poema? Este seria, segundo Sophia, um ofício nem sempre fácil: "Há poemas que aparecem prontos, outros não", confessou ela em entrevista a Eduardo Prado Coelho (COELHO, 1986).

Os "ângulos agudos e lisos" poderiam, então, traduzir a dificuldade intrínseca de escrever poesia. No caso de "Assassinato de Simonetta Vespucci", teríamos uma outra dificuldade, que seria a própria dificuldade de viver (afinal a morte, a partir do título, é o seu tema principal). Ou seja, a angústia sentida pelo homem face ao comportamento dele mesmo, homem, capaz de, muitas vezes, agir à maneira dos

\footnotetext{
${ }^{18}$ ANDRESEN, 1999, p. 196.
} 
“animais", provocando "horror" e "desordem", que, afinal, não lhe oferecem outra escapatória a não ser um fuga, testemunhada por um "silêncio agudo dos espaços".

De certa forma, a própria construção formal de "Assassinato de Simonetta Vespucci", poema desenvolvido em versos de métrica irregular e estrofes de tamanho variável, já insinua a maneira, digamos turbulenta, como será tratado o tema da morte da personagem referida no título. Aliás, vale assinalar que, embora tenha existido realmente, Simonetta Vespucci não morreu assassinada, mas de tuberculose ${ }^{19}$.

O ritmo quebrado de "Assassinato de Simonetta Vespucci" é quase como um filme em câmera-lenta. Para essa impressão colaboram certos artifícios estilísticos, como a repetição da expressão "Vê como", em anáfora, no início de quatro das seis estrofes. Ou determinados versos (no caso, exatamente dois dos que começam por "Vê como"), "Vê como os gestos se esculpem" e "Vê como pairam longamente os olhos", o primeiro a sugerir a imobilidade característica das estátuas, esculpidas de maneira a eternizar uma postura (de certa forma, esta imobilidade poderia prenunciar a própria imobilidade trazida pela morte), o segundo a indicar que os olhos estão completamente fixos (a fixidez da morte?).

A respeito da freqüente recorrência de Sophia às estátuas, como prenúncio da morte, escreve Maria de Fátima Marinho:

A morte [na poesia de Sophia] vai sendo indiciada através de alguns de seus avatares, como demonstra a recorrência dos tópicos da estátua e da máscara que desembocam nas experiências do vazio e do exílio que levam directamente à morte. (MARINHO, 2001, p. 69)

No verso "Em geometrias exactas do destino", o termo "geometrias" ganha um destaque especial, graças à aliteração verificada com "gestos", do verso anterior. Ao

\footnotetext{
${ }^{19}$ Em Florença, durante a Renascença, Simonetta Vespucci (1453/1476), "la bella Simonetta", foi conhecida por sua beleza, tendo sido modelo para os pintores Sandro Botticelli (1445/1510) e Piero di Cosimo (1462/1521). Diz-se que Botticelli teria se inspirado nela para a figura central de seus quadros A primavera e $O$ nascimento de Vênus (ambos na Galleria degli Uffizi, Florença, Itália). Segundo alguns autores, Cosimo retratou-a como Proserpina, a rainha dos infernos para os romanos (equivalente à grega Perséfone), com uma serpente sobre o colo nu (Museu Condée, Chantilly, França). Para outros, Simonetta seria, nessa pintura, a representação de Cleópatra. Num ensaio sobre o quadro, De Lisa explica que a serpente poderia signifiucar a "esperança de ressurreição da jovem, morta precocemente [...]; nessa perspectiva, a serpente é vista como um símbolo da eterna juventude" (DE LISA, 2007, trad. minha). Simonetta, ainda, teria sido motivo de disputa amorosa entre os irmãos Lourenço (1449/1492) e Juliano (1453/1478) de Médici, da família que então dominava Florença. Apunhalado 19 vezes, Juliano morreu durante um atentado contra os dois; Lourenço escapou. Ainda sobre Simonetta, seu sobrenome provém de seu marido: ela casou-se, aos 15 anos, com Marco Vespucci, parente distante do explorador marítimo Américo Vespucci (1452/1512). Há muita dificuldade em se encontrar material confiável sobre a vida de Simonetta. Com todas as ressalvas adequadas, a Internet fornece algumas informações (VESPUCCI, 2006). Em outro endereço, uma lenda associa Simonetta e Juliano de Médici ao vampirismo (MEDICI, 2006).
} 
prever "geometrias exactas" para o "destino" (que poderia ser o da personagem principal do poema, Simonetta, ou, numa acepção mais ampla, o da humanidade em geral), Sophia refere-se à precisão e ao rigor típicos da geometria (o que vem corroborado pelo adjetivo "exactas"), conferindo assim ao "destino" qualidades de imutabilidade, inflexibilidade e severidade. Num primeiro momento, tais atributos fazem-nos pensar numa prisão (o homem, então, estaria preso a um destino impossível de ser mudado), mas essa prisão equivaleria, na realidade, à morte (podemos pensar, inclusive, no rigor mortis). De qualquer modo, como vimos percebendo através de vários dos poemas aqui examinados, a morte está sempre presente no horizonte do homem; em outras palavras, o homem é homem exatamente por ser mortal.

Já notamos que, em "Dia do Mar no Ar”, o primeiro poema deste capítulo, Sophia caracteriza os "gestos" do sujeito, na primeira vez que aparecem, como "sonâmbulos" e, na segunda, como sendo "gaivotas". De uma ou de outra forma, são "gestos" que afastam o sujeito da realidade imediata, levando-o, no primeiro caso, para o mundo dos sonhos e, no segundo, para uma situação aérea, longe da materialidade terrena. Aqui, em "Assassinato de Simonetta Vespucci", os "gestos se esculpem", numa atitude incomum para o homem em seu cotidiano, lembrando-o da morte, como dissemos, ou denotando uma postura artificial, distante de sua existência normal. Esse afastamento, de certa forma, aproxima os dois poemas. No entanto, em “Assassinato de Simonetta Vespucci”, se não é exatamente uma prisão, o quarto "jaz" (outra vez a morte) "abandonado/ Cheio de horror e cheio de desordem", caracterizando um cenário que lembra aqueles onde aconteceu um assassinato violento, descritos nas reportagens ou nas histórias sobre crimes.

O "horror" e a "desordem" do "quarto (...) abandonado" de "Assassinato de Simonetta Vespucci" remetem a um poema de Geografia, "Néon", que traz, isolados numa estrofe de duas linhas, os versos "Tudo é como um interior violado /Como um quarto saqueado":

Luz descerrada e crua

Que não rodeia as coisas

Mas as desventra

De fora para dentro 
Espaço de uma insónia sem refúgio

Tudo é como um interior violado

Como um quarto saqueado

Luz de máquina e fantasma (ANDRESEN, 1999, p.27)

Numa primeira observação sobre "Néon", percebemos que seu título reflete o artificialismo noturno dos ambientes iluminados pela luz de néon, esta definida como “descerrada e crua". É nesse sentido, de uma luz que viola, mais do que revela, aquilo que ilumina, que Sophia descreve a metáfora do "quarto saqueado", como um “interior violado". Podemos perceber, na caracterização do "quarto saqueado", quase a profanação do espaço mais íntimo que o homem habita - e por extensão, do próprio íntimo do homem - não apenas por essa luz artificial, identificada no final do poema como "de máquina e de fantasma", mas, principalmente, pelo artificialismo da civilização de nossa época, de certa forma o causador da "insônia sem refúgio" que nos aflige.

De volta a "Assassinato de Simonetta Vespucci", notamos, em seus versos finais, a descrição da fuga, que menciona as portas "Abertas para os caminhos" (o adjetivo "abertas" é reiterado duas vezes), indicando uma situação anterior de aprisionamento, mas propiciando uma possibilidade de evasão, o que sugere, inclusive, a hipótese de "os homens" estarem fugindo de si mesmos.

Já nos referimos algumas vezes às portas, neste trabalho. Em relação às "portas abertas" de "Assassinato de Simonetta Vespucci', no entanto, não custa reproduzir a citação que Biedermann faz, de um texto original de Algernon Henry Blackwood, escritor inglês de histórias ligadas ao horror e ao supernatural: "Uma porta é certamente a parte mais significativa da casa. Ela é aberta e fechada; bate-se nela, tranca-se. Ela é uma soleira, um limite. Quando é atravessada para entrar ou sair, tem-se acesso a condições diferentes de existência, e isso porque ela conduz a outras pessoas, a uma outra atmosfera”. (BIEDERMANN, 1993, p. 310).

Sem dúvida, será uma outra atmosfera que aguarda "os homens", após franquearem as "portas", "abertas para os caminhos". Seria um tanto apressado supor uma atmosfera de liberdade, em oposição à situação de aprisionamento, dentro daquele "quarto", "Cheio de horror e cheio de desordem", uma vez que os "homens" 
afiguram-se como os vilões, tornados "animais" e os prováveis causadores de toda a "mágoa" sofrida pela "mulher nos seus cabelos estrangulada". De qualquer modo, as portas configuram um limite, a partir do qual tudo muda.

"Assassinato de Simonetta Vespucci" nunca menciona uma primeira pessoa. As referências são sempre a um terceiro, na maior parte das vezes os "homens" (nos primeiros versos da primeira e da quarta estrofes, no quinto verso da última). Há uma menção aos "animais" (segundo verso da quarta estrofe) e a "uma mulher" (último verso da quinta estrofe), esta, provavelmente a personagem referida no título.

A recorrência aos animais indica o grau de selvageria a que podem chegar os homens, "Vê como os homens se tornam animais". Se considerarmos selvageria como sinônimo de barbárie, vem a lembrança do que escreveu o pensador brasileiro Antonio Candido (1918), professor emérito da Faculdade de Filosofia, Letras e Ciências Humanas da Universidade de São Paulo, em "O Direito à Literatura”, texto de 1988, incluído em Vários escritos:

[...] Durante muito tempo acreditou-se que, removidos uns tantos obstáculos, como a ignorância e os sistemas despóticos de governo, as conquistas do progresso seriam canalizadas no rumo imaginado pelos utopistas, porque a instrução, o saber e a técnica levariam necessariamente à felicidade coletiva. No entanto, mesmo onde estes obstáculos foram removidos a barbárie continuou impávida entre os homens. Todos sabemos que a nossa época é profundamente bárbara, embora se trate de uma barbárie ligada ao máximo de civilização. (CANDIDO, 1995, p. 236)

Se a animalização dos homens os diminui, logo a seguir, inversamente, acontece uma sacralização dos animais (que os eleva), através dos anjos, como se sabe, figuras assíduas na poesia de Sophia ${ }^{20}$ : "E como os animais se tornam anjos". Essa sacralização, na verdade, enfatiza o aspecto selvagem dos homens, capazes de provocar tanto "horror" e tanta "desordem", através de atos violentos, cruéis e, sobretudo, injustos, pois praticados contra uma vítima aparentemente inocente. A inocência vem reforçada pela citação do lírio - flor que, como já vimos no capítulo dedicado ao silêncio, embora seja tradicionalmente associada à inocência, à pureza e à

20 As seguintes observações, a respeito da presença assídua dos anjos na poesia de Sophia, são de Maria de Fátima Marinho: "A recorrência do anjo, muito mais comum nos primeiros livros, pode assumir diversos significados, desde o tradicional adjuvante divino [...],até meras presentificações de sentimentos ou vivências [...], passando por uma espécie de espíritos do lugar que preencheriam um vazio nem sempre facilmente destruído [...].É evidente que [...] se sente a presença de Rilke e dos seus anjos impassíveis, como o do poema "L'Ange du Méridien - Chartres" [(RILKE, 1967, p.212)], ou dos anjos, afinal tão parecidos com os homens, do poema "Os Anjos" [(RILKE, 1967, p.95)]" (MARINHO, 2001, p. 62). 
própria figura dos anjos, também liga-se à morte. Como o lírio, neste poema, refere-se diretamente aos animais, "E um só irrompe e faz um lírio de si mesmo", fica ainda mais nítido o processo de humanização/sacralização dos animais e seu inverso, a animalização dos homens.

Temos, aqui, um poema certamente ambíguo, pois, como já apontamos, Simonetta Vespucci, embora tenha mesmo existido, não morreu assassinada, mas de tuberculose, aliás ainda jovem, aos 23 anos. Ao assassinar Simonetta, estaria Sophia agindo à semelhança das divindades mitológicas e tentando puni-la por causa de sua beleza, característica que a transformou em personagem histórica? Por outro lado, se pensarmos nas inúmeras vezes que Sophia inspirou-se, para se seus poemas, em vultos famosos da literatura, das artes plásticas, da política e a eles se referiu com acuidade histórica, este tropeço, no caso de Simonetta Vespucci, parece ser explicado por um engano infeliz: alguém poderia ter lhe contado os fatos de maneira equivocada, ou, quem sabe, a poeta confundiu detalhes da vida da heroína.

De qualquer maneira, não é fácil, para o pesquisador, encontrar, pelo menos no Brasil, informações impressas sobre Simonetta. A mesma dificuldade poderia ter tido Sophia. Poderíamos, talvez, concluir que a história de Simonetta vem chegando até nós quase como uma lenda, assemelhando-se às narrativas da mitologia grega que, sempre um tanto divergentes em suas várias versões.

Carlo Vittorio Cattaneo, o tradutor italiano de Sophia, ao analisar a "revisitação" que a poeta faz de "toda uma galeria de personagens", considera que temos um dado "particularmente importante, ao se levar em conta a superioridade numérica das personagens femininas, o que permite observar uma progressiva tomada de consciência dos problemas relacionados á condição da mulher na sociedade" (CATTANEO, 1983, p. 9). Após se referir ao poema "Kassandra" de Dia do mar, no qual Sophia cita, no título, a vidente Cassandra, reputada na mitologia grega por sua beleza (teríamos, aí, um ponto de contato com Simonetta Vespucci), Cattaneo argumenta:

Depois [Sophia] começou a introduzir personagens mais recentes no tempo, mais envolvidos na realidade crua das relações humanas, mas que possuem com aqueles gregos uma afinidade dialética. Exemplo, já em Coral, é o confronto entre a amarga impotência defensiva de Simonetta Vespucci frente à arrogância e à velhacaria dos sicários (homens) e à solar serenidade de Ifigénia [trata-se de "Ifigênia", poema no qual Sophia reporta-se à personagem mitológica Efigênia, filha do rei Agamenon, sacrificada durante a viagem à Tróia, "Ifigênia levada em sacrifício, /Entre os agudos gritos dos 
que a choram" (ANDRESEN, 2001, p. 204)] frente ao pranto daqueles (homens) que, não obstante a dor, não hesitaram em sacrificá-la, por razões de Estado. Nesses dois casos, a sociedade machista foi sutil e duramente criticada" (CATTANEO,1983, p. 9; trad. minha).

Embora o feminismo que Cattaneo vê em Sophia pareça um tanto exagerado, ele notou, em "Simonetta Vespucci" a alta dose de violência, que percebemos refletida, nos “olhos” da própria Simonetta, "cheios de mágoa”.

Por outro lado, um artigo do pesquisador Pedro Paula Soares, da Universidade Federal do Rio de Janeiro, descreve um outro quadro de Botticelli para o qual Simonetta teria posado. Trata-se de A primavera, no qual determinados detalhes pictóricos lembrariam o "efêmero" da "existência" da própria Simonetta:

[Em] A primavera, de Sandro Boticelli, a modelo coberta por flores [é] Simonetta Vespucci, célebre tísica [...]. A seu lado, uma ninfa em vestes diáfanas verte flores negras pela boca, em uma hemoptise floral, uma referência clássica retirada da tradição renascentista. $\mathrm{Na}$ alegoria, a valorização da jovem tuberculosa sublinha o efêmero de sua existência, sinalizado pela passagem das estações. $\mathrm{O}$ artista contribuiu para estabelecer, no plano dos cânones do belo físico, alguns parâmetros relativos à descrição dos tipos femininos. A beleza pálida, frágil, fugaz de Simonetta transformouse em uma das matrizes arquetípicas da iconografia ocidental (SOARES, 1994).

De qualquer modo, o poema vem impregnado de referências ligadas a outra figura emblemática do feminino, Ofélia, personagem que William Shakespeare colocou morta nas águas, numa famosa cena da peça Hamlet. Os versos de Sophia, "Vê como pairam longamente os olhos/ Cheios de liquidez, cheios de mágoa/ De uma mulher nos seus cabelos estrangulada", lembram essa cena, emblemática de um tipo de erotismo um tanto mórbido, ligado à imagem da mulher morta. Ofélia, a virgem afogada, corresponde, ainda, ao arquétipo da femme fragile descrito por Soares no texto acima ${ }^{21}$. Ou, como lemos no Dictionnaire des personnages de tous les temps et de tous les pays: "Doce Ofélia, doces sílabas que encerram uma juventude e uma pureza que a tragédia irá selar no momento de maior brilho. Encarnando a virgem, ela possui todos os seus dons, mas levados ao extremo, sua imagem sendo ao mesmo tempo a de uma moça e a de um anjo. O trágico, nela, reside justamente nessa

\footnotetext{
${ }^{21}$ Consultar também a respeito, o artigo da professora portuguesa Maria Manuela Gouveia Delille, da Universidade de Coimbra, "A figura da femme fragile e o mito de Ofélia, na lírica juvenil e no Só de Antonio Nobre". (DELILLE, 1993). O poema de Nobre ao qual ela se refere é "Enterro de Ofélia", escrito em 1888, cuja primeira estrofe reproduzimos a seguir: "Morreu. Vai a dormir, vai a sonhar... Deixá -la!/ (Falai baixinho: agora mesmo se ficou...)/ Como Padres orando, os choupos formam ala,/ Nas margens do ribeiro onde ela se afogou. (...) (NOBRE, 1966, p. 175)
} 
perfeição que não pode suportar nenhuma mácula, já que Ofélia significa um todo absoluto demais para conseguir participar do mal e poder se desculpar de qualquer fracasso". (OPHÉLIE, 1992, p. 730, trad. minha).

Já outro dicionário francês, de Demougin, salienta, em Ofélia, a ligação entre a verdade, a razão e a loucura, sublinhando o caráter "íntimo" da verdade: "Virgem partilhada entre seu pai, seu irmão ciumento e seu incompreensível amante, ela escolheu a loucura e se afoga, precipitando o desfecho do drama. Uma das primeiras imagens da louca como vítima completa: a razão não é dona da verdade; a verdade é um dom imediato e íntimo" (DEMOUGIN, 1992, p. 1131; trad. minha).

Percebemos que os três versos de "Assassinato de Simonetta Vespucci", que se referem à "mulher nos seus cabelos estrangulada", estão isolados numa estrofe, a quinta, última que podemos considerar curta do poema (até então, temos a primeira estrofe com três versos, a segunda e a terceira, cada uma com dois e a quarta, novamente com três). Depois, vem a sexta, que encerra "Assassinato de Simonetta Vespucci”, num padrão diferente das estrofes anteriores, apresentando seis versos. Assim, a quinta ganha certo destaque, também por trazer aquele que seria o clímax em relação à personagem principal, caso a Simonetta da verdade histórica houvesse sido realmente assassinada, ou "estrangulada", como quis Sophia.

Devido a esse destaque, a quinta estrofe merece um comentário mais detalhado. Nesse sentido, se examinarmos todos os seus termos, talvez o que chame mais atenção seja "cabelos" - e a menção aos cabelos de uma mulher não deixa de implicar num certo componente erótico.

O erotismo sugerido pelos cabelos femininos é sublinhado em um artigo da psicanalista Maria Stella de Godoy Moreira:

Entre as mulheres, o cabelo aparece como uma das armas principais da sedução. Maria Magdalena, na iconografia cristã, aparece sempre representada com cabelos longos e desmanchados, sinal de abandono a Deus, mais ainda, uma lembrança de sua antiga condição de pecadora. A noção de provocação sensual, ligada à cabeleira feminina, na tradição cristã aparece como o antigo costume de utilizar um véu sobre os cabelos ao se entrar na igreja. Os cabelos esvoaçantes da Vênus de Botticelli foram e continuam sendo a linguagem de Eros feminino. Pertencem ao cânone feminino da beleza conservando uma relação íntima com seus portadores, mesmo depois de seu corte. Conservados em relíquias, não são apenas objetos de veneração, mas também expressam um desejo de participação em suas virtudes. (MOREIRA, 2007) 
Maria Stella refere-se a duas figuras emblemáticas do feminino, a pecadora arrependida Madalena, da Bíblia, e a deusa mitológica Vênus, retratada por Botticelli em $O$ nascimento de Vênus, cuja fonte de inspiração teria sido a própria Simonetta. Embora bastante distantes uma da outra, Madalena e a Vênus de Botticelli poderiam ser aproximadas entre si, através dos cabelos, componente erótico enfatizado em suas representações iconográficas ${ }^{22}$.

A aproximação foi lembrada, em outros ternos, pelo professor e crítico de arte italiano Lionello Venturi, ao comentar a pintura: "Nas atitudes dos Ventos e da Ninfa, existe muita energia, se bem que toda ação parece ter sido evitada, pois a energia serve para emoldurar a aparição de Vênus, ídolo de timidez e ao mesmo tempo de beleza, como se Vênus se tornasse de repente tímida para que perdoássemos sua formosura, Vênus se rendendo ao pudor de Madalena" (VENTURI, 1949, p. 14; trad. minha).

A poesia de Sophia é comparada, por alguns críticos, à de Camilo Pessanha que como sabemos, é um dos precursores da poesia intimista em Portugal, na virada do século XIX para o XX. Já nos referimos a essa correspondência em alguns momentos. Retornamos a Pessanha por conta da presença, um tanto freqüente, dos cabelos femininos em seu único livro, Clepsydra. Vejamos o que notou, a respeito, a pesquisadora francesa Christine Pâris-Montech:

A palavra "cabelos" aparece dez vezes nos 56 poemas que constituem toda a obra poética de C. Pessanha; e, em oito dessas dez ocorrências, tratam-se dos cabelos de uma mulher (cf. "Madalena"; "Esvelta surge, vem das águas, nua..."; "Vênus I"; "Floriram por engano as rosas bravas..."; "Paisagens de Inverno II"; "Madrigal"; "Numa despedida..."; “A Miragem"). (PÂRISMONTECH, 1997, p. 121; trad. minha)

Em relação aos cabelos femininos, podemos encontrar, em "Assassinato de Simonetta Vespucci", um certo eco de Pessanha, nos três versos que compõem a quinta estrofe, "Vê como pairam longamente os olhos/ Cheios de liquidez, cheios de mágoa/ De uma mulher nos seus cabelos estrangulada", versos aos quais já nos referimos, ao comentar como eles evocam a figura de Ofélia.

\footnotetext{
${ }^{22}$ A Vênus retratada por Botticelli em seu Nascimento de Vênus é realmente uma imagem recorrente na literatura, quando um autor deseja descrever, com tonalidades eróticas, a cabeleira de determinado personagem feminino. É o que encontramos, por exemplo, em um dos contos de Patricia Highsmith, conhecida por suas histórias de crime com fundo psicológico, nas quais o culpado nem sempre termina punido. O conto em questão chama-se "O piano dos Steinach": "Agnes acordou com o sol brilhando no quarto [...] e se acomodou mais no fundo de seu travesseiro de penas. Distraidamente, passou os dedos pelos cabelos longos para que se espalhassem à volta de sua cabeça, como o Nascimento de Vênus, de Botticelli" (HIGHSMITH, 2005, p. 213).
} 
Com efeito, em um conhecido soneto de Pessanha, "Paisagens de Inverno II", encontramos "flutuando" os "cabelos" de uma mulher, "debaixo das águas". Devido às muitas referências à água, componente importante na caracterização do intimismo em Pessanha, "Paisagens de Inverno II" vai reproduzido por inteiro:

Passou o outomno já, já torna o frio...

- Outomno do seu riso maguado.

Algido Inverno! Obliquo o sol, gelado...

- O sol, e as águas limpidas do rio.

Aguas claras do rio! Aguas do rio,

Fugindo sob o meu olhar cançado,

Para onde me levaes meu vão cuidado?

Aonde vaes, meu coração vazio?

Ficae, cabellos d'ella, fluctuando,

$\mathrm{E}$, debaixo das aguas fugidias,

Os seus olhos abertos e scismando...

Onde ides a correr, melancolias?

- E, refractadas, longamente ondeando,

As suas mãos translucidas e frias... (PESSANHA, 1994, p. 97)

Como a figura feminina descrita por Pessanha apresenta "seus olhos abertos e scismando", seria, justamente esses "olhos" que ecoariam nos "olhos/ Cheios de liquidez, cheios de mágoa", com os quais Sophia descreve a sua Simonetta. Embora a figura de Pessanha não termine "estrangulada", como a de Sophia, o verso final de "Paisagens de Inverno II", ao se referir às "suas mãos, translucidas e frias" referemse, indubitavelmente, a alguém que já morreu; esta morte, de qualquer maneira, já estava indicada nos "seus olhos abertos", "debaixo das aguas fugidias".

Embora dedicar maior espaço a Pessanha seria um desvio do escopo desta dissertação, não podemos nos referir ao poeta sem tecer alguns comentários, ainda que rápidos, à caracterização de seu intimismo, neste soneto. Nele, o sujeito, apesar de vir rapidamente nomeado, através dos possessivos "meu" (este repetido três vezes) e "me", sempre na segunda estrofe, aparece possuído por um estado de extrema melancolia, entrevista já a partir do título, que se refere ao "Inverno", a estação mais fria do ano e, portanto, a mais melancólica. De todo modo, temos as "melancolias", no plural, expressamente nomeadas na última estrofe, numa significativa rima com “frias", que se referem às "mãos" da mulher referida no poema, provável objeto da devoção amorosa do sujeito. A composição desta mulher, com os "cabelos" "fluctuando", "debaixo das aguas", e "seus olhos abertos e scismando", se, por um 
lado, reporta-se, como a Simonetta de Sophia, à Ofélia de Shakespeare, por outro, contribui para a caracterização da angústia existencial na qual se encontra o sujeito, cujo "coração" está "vazio".

Não é no sol, fonte de calor e de vida, que o sujeito vai encontrar consolo, pois o astro mostra-se "gelado". Talvez "as aguas limpidas do rio" pudessem representar algum alívio. No entanto, "fugindo" do "olhar cansado" do sujeito, as "aguas claras do rio" correm para longe - e o que sobra é a mágoa, herdada do outono, num profundo contraste entre a limpidez e a claridade das "aguas do rio", com a tristeza sentida por alguém que perdeu sua amada.

Citando os livros A água e os sonhos, de Gaston Bachelard, e As estruturas antropológicas do imaginário, de Gilbert Durand, Christine Pâris-Montech faz algumas reflexões a respeito de "Paisagens de Inverno II" que, em certa medida, poderiam se aplicar a "Assassinato de Simonetta Vespucci", principalmente nas referências às relações entre a água, a cabeleira feminina e a morte:

[...] Gilbert Durand [sublinha o] simbolismo da água e da cabeleira feminina, e [a] "contaminação" da primeira pela segunda ${ }^{23}[\ldots]$. E em Pessanha, como em tantos artistas e em tantos outros poetas, pode-se perceber, simultaneamente, [segundo Bachelard ${ }^{24}$ ], uma feminilização da água e uma ofelização da figura feminina, ambas fazendo-nos lembrar daquele pavor, anunciado por Heráclito, da fuga do tempo, [assim como] da idéia da morte. Isso porque, [citando Durand ${ }^{25}$, este por sua vez inspirado em Bachelard] "ao ondular, a cabeleira traz imagem aquática e vice-versa" - devido ao evidente isomorfismo entre ambas. [Assim,] o vínculo profundo que une a representação da água corrente à do tempo que se escoa, faz com que [citando mais uma vez Durand $\left.{ }^{26}\right]$ " [...] na poesia, a ondulação da cabeleira está ligada ao tempo, a esse tempo irrecuperável que é o passado". (PÂRIS-MONTECH, 1997, p. 123; trad. minha)

Numa última alusão a Pessanha, recordemos outro de seus sonetos, "Ó Magdalena", do qual citaremos apenas os dois primeiros versos, "Ó Magdalena, ó cabellos de rastos, /Lirio polluido, branca for inutil...” (PESSANHA). Essa

\footnotetext{
${ }^{23}$ Durand faz uma série de observações, relacionando a cabeleira feminina à água e afirmando que "o que constitui a irremediável feminilidade da água é que a liquidez é o próprio elemento dos fluxos menstruais" (DURAND, 2001, p. 101). Em seguida, após citar várias personagens femininas mitológicas e literárias, conclui que: "[...] o simbolismo da cabeleira parece vir reforçar a imagem da feminilidade fatal [...]. A cabeleira não se liga à água por ser feminina, mas, pelo contrário, feminiza-se por ser hieróglifo da água, água cujo suporte fisiológico é o sangue menstrual" (DURAND, 2001, p. 107).

${ }^{24}$ A água e os sonhos, p. 109 e p. 125.

${ }^{25}$ As estruturas antropológicas do imaginário, p. 99.

${ }^{26} I d$., p. 100.
} 
"Magdalena", nas palavras de Christine Pâris-Montech, aparece "como uma criatura vulnerável, ferida, ou mesmo morta" (PÂRIS-MONTECH, 1997, p. 123, trad. minha). Através da fragilidade, ou do estado de morta, Simonetta poderia ser associada a ela, notando-se que, além dos "cabellos", também o "lírio" constitui um elemento simbólico que aproxima os dois poemas.

Com relação ao intimismo de Sophia que estamos estudando, notamos que, em “Assassinato de Simonetta Vespucci”, quatro das seis estrofes estão marcadas pelo "Vê", que as inicia. Pois, em um outro poema de Coral, "Acordo", encontramos, também, um verbo ligado à visão, acordar. "Acordo" não menciona diretamente a prisão; visualizamos, porém, seu sujeito poético completamente murado por um medo intenso, em seu quarto, logo ao acordar:

Acordo quando os muros são o medo,

Acordo quando o tempo cai contado,

E no meu quarto entra o arvoredo,

E se desfolha ao longo dos meus membros.

Acordo quando a aurora nas paredes

Desenha nardos brancos e macios,

Acordo quando o sonho nos convence

De que sois rios. (ANDRESEN, 2001, p. 179)

O poema relembra o papel fundamental do quarto na vida do sujeito ${ }^{27}$, pois se trata do espaço onde ele acorda todos os dias - acordar, por sinal, que remete ao próprio nascimento do homem. A repetição anafórica dos termos "Acordo quando", no primeiro e no segundo verso da primeira estrofe, e no primeiro e no quarto da segunda, enfatiza a importância do ato de acordar, que define a parte do dia na qual o homem estará desperto, portanto atento ao mundo que o cerca. Este estado de atenção opõe-se ao do homem dormindo e, assim, afastado da realidade próxima, imerso no "sonho", que "nos convence de que sois rios".

Através do "sois", Sophia introduz no poema uma segunda pessoa, à qual o sujeito se dirige apenas no último verso, comparando-a a "rios", imagem da água em

\footnotetext{
${ }^{27}$ A esse respeito, vale citar o que lemos na contracapa de O quarto de dormir: um estudo etnológico, do etnólogo francês Pascal Dibie: "o quarto de dormir foi e continua sendo a peça mais importante da habitação, onde o homem passa pelo menos a terça parte de seu tempo. (DIBIE, 1988)
} 
movimento, de rica conotação simbólica. De certa forma, a água também é referida indiretamente no segundo verso, "quando o tempo cai contado" (grifo meu). Embora a primeira e mais rápida associação do verbo cair, nesse verso, relacione-o ao movimento da areia caindo numa ampulheta, é possível lembrar, também, da águas que caem, numa cachoeira, por exemplo, à semelhança das águas do rio, que passam e não voltam mais, sinalizando, assim, a passagem do tempo.

Por outro lado, o "tempo contado" pode ser interpretado como a medição do tempo feita pelo homem, assinalando a passagem dele pela terra em dias (o homem acordado) e noites (o homem sonhando), cuja sucessão sinaliza o próprio ciclo eterno da natureza. Nesse sentido, a importância da "aurora" é sinalizada, na segunda estrofe, quando esta "nas paredes/ Desenha nardos brancos e macios". A "aurora" corresponde, ainda, a outra imagem do nascimento e está associada aos "nardos", planta perfumada que Sophia freqüentemente escolhe quando quer enfatizar um caráter de pureza ou preciosidade ${ }^{28}$. Quanto à cor branca, embora já tenhamos nos referido a ela nesta dissertação, gostaríamos de assinalar o quanto ela reforça, neste poema, essa qualidade de pureza sugerida pelos "nardos". Nesse sentido, vale citar duas passagens de Sophia, nas quais a cor branca evidencia isso, ambas retiradas do texto poético "Caminho da manhã", de Livro sexto.

No primeiro trecho, temos:

(...) Aí deves parar e olhar um instante para o largo pois ali o visível se vê até o fim. E olha bem o branco, o puro branco, o branco de cal onde a luz cai direto. (...) (ANDRESEN, 1991, p. 105)

Além de salientar "o branco, o puro branco" (grifo meu), o trecho relaciona o "branco" ao "visível que se vê até o fim", privilegiando a visão como modo de percepção do universo, constante na poética da autora.

Mais adiante, lemos, ainda em "Caminho da Manhã" (aliás, o próprio título refere-se à "manhã”, parte inicial e mais radiosa do dia, que guarda nítida relação com o verbo acordar, de "Acordo"):

\footnotetext{
${ }^{28}$ O dicionário de Chevalier e Gheerbrant, acentuando a preciosidade do nardo, lembra que se trata de "planta desconhecida no Ocidente, mas amiúde citada pelos autores orientais", complementando: " Extraía-se do nardo um perfume dos mais preciosos, que evocava qualidades régias. [...] Ele [segundo uma descrição bíblica], entra na composição do Paraíso, onde desabrocha o amor" (CHEVALIER \& GHEERBRANT, 1999, p. 630).
} 
(...) Caminha até encontrares uma igreja alta e quadrada. Lá dentro ficarás ajoelhada na penumbra olhando o branco das paredes e o brilho azul dos azulejos. Aí escutarás o silêncio. Aí se levantará como um canto o teu amor pelas coisas visíveis que é a tua oração em frente do grande Deus invisível. (ANDRESEN, 1991, p. 105)

Neste segundo fragmento de "Caminho da manhã" além de temos o "branco" diretamente relacionado ao "silêncio", importante item da poética intimista, analisado em detalhe no Capítulo 1, percebemos, mais uma vez, o realce que Sophia coloca nas "coisas visíveis", enfatizando esta visibilidade através do contraste com a qualidade de "invisível" que caracteriza o "grande Deus".

Voltando a "Acordo", se nos fixarmos no primeiro verso do poema, "Acordo quando os muros são o medo", percebemos um ser amedrontado por "muros", elemento que, em termos de poética intimista, reporta-se aos obstáculos que se contrapõem ao sujeito, privando-o de um maior e melhor contato com o ambiente à sua volta. Segundo Cirlot, os muros podem ser considerados como um exemplo extremo das "paredes" (que, neste poema, aparecem na segunda estrofe). Cirlot explica, a respeito do muro:

Como parede, que fecha o espaço, é o "Muro das Lamentações" símbolo do sentimento de "caverna" do mundo, do imamentismo, da impossibilidade de [acessar] o exterior. (CIRLOT, 1984, p. 396).

Em um ensaio a respeito do poema "Andaime", de Fernando Pessoa, o escritor português José Leon Machado, considera o muro como "símbolo de cárcere":

A simbologia do muro [...] tem a sua importância para a compreensão do poema. O muro simboliza a comunicação cortada, interrompida. Pode servir para defesa, protecção, mas é ao mesmo tempo símbolo de cárcere. (MACHADO, 2006)

No poema "Acordo" a janela, outro componente importante do intimismo, não aparece explicitamente. Mas os dois últimos versos da primeira estrofe descrevem o "arvoredo" que "entra", à primeira vista numa espécie de ameaça ao sujeito, e "se desfolha ao longo dos meus membros", numa imagem antropomórfica (recurso, como vimos, bastante utilizado pela poeta) que, por isso mesmo, leva a uma idéia de 
comunhão total com a natureza, ideal perseguido por Sophia em muitos de seus poemas.

Percebemos que, analisadas isoladamente, as duas estrofes de "Acordo" como que brigam entre si, devido aos termos negativos da primeira ("muros", "medo", “cai”, "desfolha”), que se opõem aos positivos da segunda ("aurora", "nardos brancos e macios", "convence"). Como já notamos, Sophia é hábil na criação desses contrastes, que ajudam na criação de uma certa tensão poética, capaz de seduzir o leitor em sua leitura. Por outro lado, o desenho gráfico do poema, apresentando sete de seus oito versos de tamanho semelhante, só com o oitavo e último significativamente menor, faz os olhos de quem lê convergirem (caírem?) diretamente para os "rios", ou melhor, para o verso todo, "De que sois rios", chamando a atenção, assim, tanto para esta enigmática segunda pessoa, como para o componente água, de tão vívida conotação simbólica, presente em "rios".

Em relação ao rio, Geografia inclui um poema, "Portas da vila", que traz um "quarto atravessado pelo rio":

\section{I}

A casa está na tarde

Actual mas nos espelhos

Há o brilho febril de um tempo antigo

Que se debate emerge balbucia

\section{II}

Com um barulho de papel o vento range na palmeira

O brilho das estrelas suspende o nosso rosto

Com seu jardim nocturno de paixão e de perfume

A casa nos invade e nos rodeia

III

A casa vê-se de longe porque é branca

Mas sombrio

É o quarto atravessado pelo rio

IV 
A casa jaz com mil portas abertas

O interior dos armários é obscuro e vazio

A ausência começa poisando seus primeiros passos

No quarto onde poisei o rosto sobre a lua (ANDRESEN, 1999, p. 55)

O primeiro elemento enunciado neste poema é "A casa", reproduzido anaforicamente na abertura da terceira e da quarta estrofes. Aliás, cada estrofe aparece introduzida por um numeral, como se o poema fosse dividido em capítulos. No entanto, o tema que percorre todas as estrofes permanece, sempre, o mesmo, o da "casa" como ponto de referência para o sujeito, este enunciado primeiramente no plural, na segunda estrofe ("nosso rosto", grifo meu) e, pela segunda e última vez, no singular, no derradeiro verso do poema ("No quarto onde poisei o rosto sobre a lua", grifo meu).

Seja ao recordar um tempo já passado, que volta insistente para a memória do sujeito ("Há o brilho febril de um tempo antigo/ Que se debate emerge balbucia"), provavelmente como recordação da sua infância (o que é sugerido pelo verbo balbuciar), seja pela sugestão de um abrigo limpo e não contaminado pelas impurezas do mundo ("A casa vê-se de longe porque é branca", grifo meu), a presença insistente da casa, em "Portas da Vila", relaciona-se com todas aquelas observações que fizemos sobre a habitação do homem, no Capítulo 1. Na verdade, incluímos o poema neste Capítulo 3, pela possível ressonância com "Acordo", cujo par de versos "Acordo quando o sonho nos convence/ De que sois rios", de certa forma ecoa imageticamente em "É o quarto atravessado pelo rio", do poema agora analisado.

O rio, como se sabe, possui notável conotação simbólica. Lemos em Chevalier e Gheerbrant: "O simbolismo do rio e do fluir de suas águas, é, ao mesmo tempo, o da possibilidade universal e o da fluidez das formas [segundo o filósofo e poeta suíço Frithjof Schuon], o da fertilidade, da morte e da renovação. O curso das águas é a corrente da vida e da morte.[...] Seja a descer as montanhas ou a percorrer sinuosas trajetórias através dos vales, escoando-se nos lagos ou nos mares, o rio simboliza sempre a existência humana e o curso da vida, com a sucessão de desejos, sentimentos e intenções, e a variedade de seus desvios" (CHEVALIER E GHEERBRANT, 1999, p. 780 e 781). 
Em “As Portas da Vila”, temos um "quarto atravessado pelo rio", quarto no qual, assim como no rio, o seu habitante encontra refletida toda a sua vida, incluindo tanto os momentos bons, como os ruins.

Em oposição flagrante à brancura da "casa", tão "branca" que "vê-se de longe", o quarto encontra-se "sombrio", já que Sophia, como sempre, mostra certa insistência na descrição das sombras e das penumbras. Por um lado, o cenário “sombrio" estaria favorecendo o exercício de introspecção do sujeito, por apresentar condições de semi-obscuridade, que facilitariam a meditação; por outro, poderiam ser resultado da própria introspecção, refletindo as lembranças desagradáveis que o eu recorda.

Referimo-nos aos momentos bons e ruins da vida do sujeito. Numa observação sobre o quarto, o etnólogo Paul Dibe, que já citamos em nota, algumas páginas atrás, fala das lembranças, anódinas ou essenciais: "Ninhos dispostos no centro de nossos pontos de referencia, os quartos são as pecas em que fazemos constantes e prolongadas estadias interiores. Se essas espécies de espaços ${ }^{29}$, no dizer de Georges Perec, bastam para reanimar, renovar e reavivar tanto as lembranças mais anódinas como as mais essenciais, infelizmente, porém, nossa sociedade moderna orgulha-se da normalização de tudo que se refere ao homem" (DIBE, 1988, p. 183).

Vale ressaltar, no texto, a importância conferida ao quarto, como ambiente especialmente favorável às operações do intimismo, por parte do sujeito. Muito a propósito, Dibe define os quartos como ninhos, isto é, como lugares nos quais podemos nos sentir protegidos contra as vicissitudes, quase como no ventre materno. Todavia, ressalta o autor, à introspecção e à proteção sugeridas pelo quarto, opõe-se a normalização de nossa sociedade moderna, ou seja, a massificação à qual está sujeita o homem do fim do século XX e início do XXI.

Curtas no tamanho, as estrofes de "Portas da Vila" foram compostas com versos irregulares, sem preocupações quanto a rimas, aliterações, ou outros recursos poéticos tradicionais. Três delas apresentam quatro versos cada, com exceção da terceira, justamente aquela que introduz o quarto, colocado, assim, em posição de destaque no poema.

No entanto, a contenção de meios é apenas aparente. "Portas da Vila", com efeito, carrega, em seus poucos versos, inúmeras imagens de sugestivo vigor poético.

\footnotetext{
${ }^{29}$ Título do livro de Perec, ao qual já nos referimos no Capítulo 1.
} 
Ao lado da "casa" e do "quarto", e de outros elementos aos quais já nos referimos na análise de poemas anteriores, como os "espelhos", as "estrelas", o "jardim" (aqui, definido como "nocturno" e, portanto, associando à sua própria simbologia a da noite) e as "portas", todos eles importantes para a caracterização do estilo intimista, temos um outro item, a "palmeira", introduzido com certo destaque, pois é o último termo do verso mais longo do poema. Esse verso, aliás, vibra com intensa sonoridade, através da metáfora com a qual Sophia descreve o ruído produzido pelo vento nas folhas da palmeira: "Com um barulho de papel o vento range na palmeira".

De qualquer modo, a palmeira, por si só, relaciona-se a uma simbologia particular. Biedermann lembra uma citação bíblica, para em seguida, apontar a conotação altamente positiva dessa planta: "O significado simbólico judaico-cristão da palma deriva antes de tudo de um trecho dos Salmos $(91,13)$ : 'O justo florescerá como a palma'.[...] De modo geral, por causa de seu tronco reto e fino e de sua coroa exuberante, ela é considerada uma referência à ascensão, à vitória e ao renascimento.”(BIEDERMANN, 1993, p. 278)

"No quarto", também de Geografia, recorre ao "quarto" para narrar a situação de um sujeito aparentemente aprisionado:

No quarto roemos o sabor da fome

A nossa imaginação divaga entre paredes brancas

Abertas como grandes páginas lisas.

O nosso pensamento erra sem descanso pelos mapas

A nossa vida é como um vestido que não cresceu connosco

(ANDRESEN, 1999, p. 49)

O sujeito, enunciado no plural, ao roer "o sabor da fome", lembra a situação de um indivíduo sofrendo um extremo sacrifício, podendo, mesmo, se reportar a alguém encarcerado e recebendo uma pena de pouca (ou nenhuma) alimentação. A menção às "paredes brancas", ao mesmo tempo que faz eco a dois poemas que estudamos no Capítulo 1, "III” (que traz o verso "As paredes são brancas e suam de terror"), e "Instante" (no qual lemos a estrofe Deixai-me limpo/ O ar dos quartos/ E liso/ O branco das paredes), sugere um limite físico a isolar o ocupante deste "quarto". Além de "brancas" (ou, justamente por serem dessa cor), as "paredes" abrem-se (termo que se opõe aos próprios limites representados pelas "paredes") "como grandes 
páginas lisas", aludindo, metaforicamente, tanto àquela "página em branco/ Onde o poema emerge", verso de "Revolução" ao qual já nos referimos anteriormente, neste capítulo, quanto a um outro tipo de página, desta vez dos "mapas" mencionados em "No Quarto". Ao abrirem-se para estes "mapas", as "paredes brancas" estariam, então, sugerindo ao sujeito a possibilidade de uma escapada, através de possíveis viagens, reais ou imaginárias (o nome do livro ao qual pertence "No Quarto", vale lembrar, intitula-se Geografia), que o libertariam da angústia em que vive. Essa angústia traduz-se no último verso do poema, "A nossa vida é como um vestido que não cresceu connosco", bela imagem para descrever um estado de sofrimento, uma vez que traz a lembrança da infância, nesta vestimenta "que não cresceu" (grifo meu), acompanhando o sujeito. Trata-se, aliás, de uma figuração um tanto recorrente na obra de Sophia, ocorrendo, por exemplo, também em "Igrina" (só que ao contrário, como veremos), texto poético que abre Geografia e que reproduzimos abaixo:

O grito da cigarra ergue a tarde a seu cimo e o perfume do orégão invade a felicidade. A omnipotência do sol rege a minha vida enquanto me recomeço em cada coisa. Por isso trouxe comigo o lírio da pequena praia. Ali se erguia intacta a coluna do primeiro dia - e vi o mar reflectido no seu primeiro espelho. Igrina.

É esse o tempo a que regresso no perfume do orégão, no grito da cigarra, na omnipotência do sol. Os meus passos escutam o chão enquanto a alegria do encontro me desaltera e sacia. O meu reino é meu como um vestido que me serve. E sobre a areia sobre a cal e sobre a pedra escrevo: nesta manhã eu recomeço o mundo. (ANDRESEN, 1999, p. 11, grifo meu)

Aqui, o "vestido" cresceu juntamente com o sujeito, pois "me serve", constatação tão plena como a de "O meu reino é meu", celebrando, em tom epifânico, a plenitude perfeita da integração do indivíduo com tudo aquilo que o cerco.

Para encerrar, um poema famoso, de $O$ nome das coisas, "Por Delicadeza", no qual Sophia parafraseia o poeta francês Arthur Rimbaud, paradigma do modernismo:

Bailarina fui 
Mas nunca dancei

Em frente das grades

Só três passos dei

Tão breve o começo

Tão cedo negado

Dancei no avesso

Do tempo bailado

Dançarina fui

Mas nunca bailei

Deixei-me ficar

Na prisão do rei

Onde o mar aberto

E o tempo lavado?

Perdi-me tão perto

Do jardim buscado

Bailarina fui

Mas nunca bailei

Minha vida toda

Como cega errei

Minha vida atada

Nunca a desatei

Como Rimbaud disse

Também eu direi:

"Juventude ociosa

Por tudo iludida

Por delicadeza

Perdi a minha vida" (ANDRESEN, 1999, p. 241) 
Trata-se de um poema constantemente citado, inclusive por um dos filhos de Sophia, o jornalista Miguel de Souza Tavares, que escreveu o artigo "E ela dança", para o jornal português Público, em 1999, do qual reproduzimos apenas dois parágrafos, o primeiro e o último:

Às vezes, quando a casa estava adormecida à noite, ela dançava pela sala fora, tal qual como escreveu ("bailarina fui mas nunca bailei"). Às vezes, convencia-se que havia ladrões em casa e acordava-me do sono para espreitar debaixo da minha cama, e às vezes havia ladrões a sério, com cara de assassinos e crachá da PIDE, que chegavam pela alvorada do dia, mas verdadeiramente ela não tinha medo dos ladrões nem dos esbirros do "velho abutre": só tinha medo de fantasmas. [...]

A outra lição decisiva foi a da liberdade. Não só a liberdade física, não só a liberdade na luta pela justiça, "num sítio tão imperfeito como o mundo", mas ainda a liberdade na busca de um caminho próprio onde as coisas tenham uma ética e façam sentido e, acima de tudo, a liberdade da nossa própria solidão. Prémios, condecorações, homenagens, são-lhe de tal forma alheios que ninguém mais o entende. Dêem-lhe, sim, silêncio e tempo, manhãs como a "manhã da praça de Lagos" e noites com "jardins invadidos de luar". E ela dançará. Ao longo das sílabas dos poemas, como dançava na minha infância. ( TAVARES, 1999)

Dançar sempre foi um verbo importante para a poeta que, inclusive, cismou em grafá-lo, em alguns poemas, à sua própria maneira, com "s", ao invés de "ç",30. Um exemplo é "Puro Espírito", de No tempo dividido:

Puro espírito do êxtase e do vento

Que no silêncio da planície dansas

Eu não quero tocar teu corpo de água

Nem quero possuir-te nem cantar-te

Pesa-me já demais a minha mágoa (ANDRESEN, 1991, p. 28)

O sujeito dialoga com um interlocutor, sublimado na força do "vento", que dansa (quem dansa? o interlocutor? o vento?) no cenário de "silêncio" de uma "planície". Mas o interlocutor apresenta-se, também, numa forma dissolvida, "teu corpo de água". Assim, acaba rejeitado pelo sujeito, através de enfáticas negativas: ao

\footnotetext{
${ }^{30}$ A propósito da insistência de Sophia em grafar dança com "s", vale citar "Dansa", curioso poema do poeta e escritor português Gonçalo M. Teixeira, nascido em Angola e residente em Portugal. Pouco após a morte da poeta, Gonçalo homenageou-a com uma série de poemas, cujos títulos referem-se a elementos recorrentes na obra de Sophia: "Pedra", "Mesa", "Dansa", "Claridade", "Canto", "Destino", "Chão", "Vida", "Espanto", "Vento", “Jardim", "Mar”. Desses, o anexo F reproduz "Dansa”.
} 
sujeito o que importa, acima de tudo, é a "mágoa", “minha” (portanto íntima) e pesada.

Em "Dansa", poema de apenas três versos, de Coral, o "quarto" vem colorido por uma cor pouco citada por Sophia, o "verde":

O quarto verde, os peixes da penumbra

Peso duplo do corpo no vazio

Gesto dilacerando os nós do frio (ANDRESEN, 2001, p. 241)

O poema menciona a "penumbra", o "vazio" e o "frio", alguns dos vetores do intimismo mais comentados por nós, mas tratados de maneira um tanto inédita, não só pela cor "verde". O "peso duplo do corpo no vazio" parece duplicar a sensação de incômodo sentida por um sujeito não nomeado. A indefinição contribui para certo tom surrealista do poema, percebido, principalmente, nos "peixes" que a "penumbra" forma, como num sonho irreal. No entanto, o "peso duplo do corpo", o "vazio" e o "gesto dilacerando os nós do frio" constituem indícios de desconforto muito reais, quase palpáveis, apontando para o desconcerto íntimo de um sujeito que, mesmo invisível, se torna muito presente, através desses elementos.

A "Dansa", um tanto surpreendentemente, aparece só no título, abrindo espaço, como em outros poemas de Sophia, para discussões e hipóteses várias. Mesmo porque Sophia nem sempre grafa "dança" com "s", como vemos em "Por Delicadeza" e, para citar outro exemplo, no verso "Inventei a dança para me disfarçar" (ANDRESEN, 1991, p. 29), no poema imediatamente seguinte a "Puro Espírito", em Coral.

As idiossincrasias ortográficas de Sophia, de qualquer modo, dão margens a muitas teorias. Para citar apenas uma, eis o que disse João Ribeirete: "a ortografia de Sophia, para lá de conservadora, tem também aquilo a que poderíamos chamar de expressionismo visual. De recordar a ortografia da palavra "dansa", com o movimento sinuoso de uma dança impresso na opção do grafema "s" (RIBEIRETE, 2007).

Mais importante, no entanto, é notar que, em "Por delicadeza", a dança aparece como metáfora para a liberdade (liberdade também mencionada no artigo de Miguel Souza Tavares), em oposição à prisão, enfatizada, na terceira estrofe, por ser “a prisão do rei”, ou seja, um cárcere efetivamente real, comandado por aquele que manda. 
Podemos nos referir a "Por Delicadeza" como um poema coreográfico, pois a composição em redondilhas favorece a sugestão da dança. $\mathrm{O}$ sujeito encontra-se às voltas com um "tempo bailado" (seria um tempo de equívocos, um tempo não vivido, semelhante à vida perdida de Rimbaud?), no qual a censura e o tormento representado pelas "grades" opõem-se ao "tempo lavado", limpo, puro, metaforizado no "mar" e no "jardim".

Em "Por Delicadeza" não aparece o quarto. Notamos, porém, o sujeito querendo livrar-se a si mesmo de um enclausuramento imposto pelos hábitos e pelas regras de um mundo que mantém a "minha vida atada", presa "toda" (o termo é do poema) ela a um conjunto de circunstâncias tão inúteis quanto imperiosas, frente às quais este sujeito só encontra negativas. Com efeito, o advérbio "nunca" é repetido em quatro das sete estrofes, enquanto na segunda, ao invés do advérbio, temos o próprio verbo negar, em sua forma de particípio e contraposto ao "avesso", esse que é o lado escondido das coisas e da vida. O lado errado? A vida avessa de Rimbaud?. De certo modo, também, o outro lado do espelho, elemento tão freqüentemente citado por Sophia. 


\section{CONCLUSÃO}

Quando o jornalista e escritor português Eduardo do Prado Coelho comentou, numa entrevista, que Sophia teria um "léxico muito concentrado e até utilizando a repetição, a repetição voluntária, premeditada", a poeta lhe respondeu:

Há um poema de João Cabral de Melo em que ele diz: "Escrevo com vinte palavras". As palavras têm que ser exactamente as palavras que conquistámos, quer dizer, não são só as palavras que sabemos: são as palavras que viveram e viverão connosco. Além disso, eu sou muito repetitiva de natureza... (COELHO, 1986)

Na mesma entrevista, a uma observação do entrevistador sobre "a importância das casas, das velhas casas, dum certo tipo de casas, tanto nos seus contos como também na poesia”, Sophia explicou:

Tenho muita memória visual e lembro-me sempre das casas, quarto por quarto, móvel por móvel e, lembro-me de muitas casas que desapareceram da minha vida, como por exemplo, a casa dos meus avós que foi leiloada, vendida, as coisas dispersas... Eu penso que há em todo o homem, em todo o poeta, uma tentativa para conservar uma eternidade que está latente nas coisas, porque no fundo, todos nós amamos as coisas sob um olhar de eternidade mesmo que depois vejamos as coisas desfazerem-se... Eu tento "representar", quer dizer, "voltar a tornar presentes", as coisas de que gostei e é isso o que se passa com as casas; quero que a memória delas não vá à deriva, não se perca. (COELHO, 1986)

As duas respostas de Sophia deixam bem claras duas de suas principais preocupações, que ela deixou expressas de maneira veemente em sua obra: o cuidado com a escolha das palavras utilizadas em sua poesia e a dimensão da eternidade, frente à dimensão finita do homem. 
Quando fala sobre as "vinte palavras" de João Cabral de Melo Neto ${ }^{31}$, é como se Sophia se referisse à sua própria poesia, tão profunda é a identificação que se nota entre ela e o poeta brasileiro, como, aliás, já havíamos apontado na Introdução. Assim, recorrendo, mais uma vez, a "Arte Poética II", texto de Sophia, que citamos também na Introdução, poderíamos identificar, entre as "vinte palavras", agora como sendo também as de Sophia, aquelas que ela menciona, ao se referir à "vida concreta" de sua poesia: "Por isso, o poema não fala de uma vida ideal mas sim de uma vida concreta: ângulo da janela, ressonância das ruas, das cidades e dos quartos, sombra dos muros, aparição dos rostos, silêncio, distância e brilho das estrelas, respiração da noite, perfume da tília e do orégão.[...] (ANDRESEN, 1999, p. 95)

Através da série de poemas que analisamos, algumas vezes verso a verso, nos três capítulos desta dissertação, tentamos apontar como alguns desses elementos, em especial o representado pelo ambiente do quarto, contribui para expressar, no que respeita à linguagem intimista, a problemática existencial do homem, considerando o seu horizonte finito em relação à dimensão da eternidade.

Para conseguir enxergar o cosmos, o homem volta-se para dentro de si mesmo. Ele tenta encontrar solução para sua angústia interior, muitas vezes reflexo do mundo fragmentado da segunda metade do século XX. O período, iniciado e marcado por um acontecimento trágico, a II Guerra, acompanhou a tecnologia chegar a patamares nunca antes alcançados. No entanto, não era de respostas tecnológicas que o homem precisava, para resolver suas dúvidas existenciais. Sophia, que escreveu seus 14 livros de poesia exatamente nesse período, utilizou as "vinte palavras" num estilo ímpar, muitas vezes repetitivo, como ela mesma reconheceu, na entrevista que reproduzimos acima. A repetição, talvez, reflita algo como sucessivas tentativas, cada vez mais insistentes, de estabelecer uma saída final, definitiva para o homem. No entanto, final e definitiva parece ser sempre a morte; Sophia não se deu por vencida e conseguiu construir, não só a partir das "estrelas", mas também a partir do ponto de vista real e concreto das "coisas" que nos rodeiam, o arcabouço poético de uma perspectiva ao mesmo tempo cósmica e terrestre, que coloca o homem ao mesmo tempo no centro, no início e no fim do mundo em que vive.

\footnotetext{
${ }^{31} \mathrm{Na}$ verdade, estes são os versos João Cabral de Melo Neto: "Falo somente com o que falo:/ com as mesmas vinte palavras" (MELO NETO, 1973, p. P. 56). Estão no poema "Graciliano Ramos", do livro Serial, de 1961. Um comentário do poeta Frederico Barbosa: "Falo somente com o que falo: a linguagem enxuta, cortante e densa" (BARBOSA, 2007).
} 
Analisar poesia através de um viés intimista constitui um procedimento relativamente recente, sobre o qual não existe muito material bibliográfico especifico, principalmente no Brasil. Para entender a perspectiva do intimismo, é necessário nos voltarmos, também, para o estudo da literatura e da sociedade a partir de meados do século XIX, época em que o homem começou a aprender a ser moderno. Uma das maneiras como isso se refletiu, na vida pessoal de cada indivíduo, foram as significativas mudanças no estilo de morar, através do despertar da consciência de cada um para o seu próprio espaço privado.

O filósofo Walter Benjamin escreveu um ensaio bem esclarecedor a esse respeito. Trata-se de "Paris, Capital do Século XIX", que aponta como o período, em vários aspectos, foi prenunciador do século $\mathrm{XX}$, através dos significativos avanços representado pelas novidades arquitetônicas e urbanísticas, pela fotografia, pela poesia de Baudelaire, pela "peregrinação ao fetiche mercadoria” (BENJAMIN, 1985, p. 35), pelos sucessos das barricadas populares...

O ensaio inclui uma afirmação do historiador Jules Michelet,"Cada época sonha a seguinte", que enfatiza o caráter vanguardista da época. Quanto aos avanços em si, ao refletir sobre a contribuição que trouxeram para revolucionar a sociedade e, também, a vida particular das pessoas, Benjamin conclui que "pela primeira vez, o espaço em que vive o homem privado se contrapõe ao local de trabalho" (BENJAMIN, 1985, p. 37).

Não é mera coincidência que estilos de decoração que permitiram uma expressão mais distinta, diferente e quase exclusiva da personalidade, como o artnouveau, tenham surgido na transição do século XIX para o XX. O homem estava recém-descobrindo o que Benjamin denominou de interieur, significando tanto o interior da casa a ser decorado (melhor dizendo, abarrotado, para nos atermos ao gosto da época), como aquela essência íntima que cada um carrega bem guardada dentro de si. Ou, nas palavras do filósofo, "o homem privado, realista no escritório, quer que o interieur sustente suas ilusões" (BENJAMIN, 1985, p. 37).

Já nos referimos, na Introdução, ao grupo de poetas portugueses que, na virada dos oitocentos para os novecentos soube transmitir, através da poesia, o desconforto existencial que parecia ser cada vez maior, na exata medida do desenvolvimento extraordinário do capitalismo e da industrialização. A resposta poética veio por meio de imagens da desilusão, da melancolia, do tédio. E também através de todos aqueles ingredientes tão caros ao simbolismo, tais como o gosto pelo vago e pelo irreal, as 
paisagens nebulosas e outonais, a insistência nas recordações de uma infância mais amena, a dolorosa percepção da efemeridade da vida. Um sofrimento profundo marcou a linguagem intimista desses poetas de Portugal, num contexto onde a dor íntima, muitas vezes, foi igualmente sinônimo da melhor poesia.

Não pretendemos, aqui, resumir a história da poesia portuguesa nos séculos XIX e XX. No entanto, sintetizando um intervalo de aproximadamente cem anos numa única sentença, diríamos que àquela dor dos poetas do oitocentos, os poetas do novecentos souberam reagiram com o domínio sobre a palavra, com a consciência clara da linguagem como o melhor vetor para o conhecimento da realidade.

Sophia de Mello Breyner Andresen, nos anos cruciais imediatamente posteriores à II Guerra, soube como poucos - já dissemos, na Introdução, que são três os grandes poetas portugueses do período, ela, Eugénio de Andrade e Jorge de Sena captar a problemática de um mundo fragmentado, filtrando-a através de um estilo característico e muito pessoal, exorcizando os demônios do íntimo do sujeito com a mesma serenidade com a qual nomeava as coisas. Mas não é só. Valendo-se da capa ancestral herdada da mitologia, com o mesmo conhecimento que lhe permitia dedicar poemas a Camões, Byron ou Pessoa, viajando pelo Mediterrâneo, Grécia ou Brasil com curiosidade igual à de quando explorava as praias portuguesas. E ainda: interpretando as cores e os espaços de Vieira da Silva, lendo os "espantos" de Manoel Bandeira, dansando com o mesmo júbilo com o qual descreveu as maravilhas, os esplendores e as mazelas do mundo.

Isso tudo é bastante, mas também é pouco, porque a poesia de Sophia significa tudo e muito mais. Consciente da importância tanto do $e u$, quanto da palavra, ela conseguiu realizar, por meio de sua poesia, um extraordinário cruzamento poético entre os nomes, as coisas e o sujeito, transitando, muito à vontade, entre a realidade visível, mas finita, e a eternidade cósmica. Realmente, seus poemas demonstram uma invejável familiaridade mesmo com temas complexos, como se o mundo, para ela, embora parecesse não ir mais além das árvores frutíferas do quintal, ou de uma maçã esquecida sobre a mesa, estivesse, ao mesmo tempo, iluminado pela grandiloqüência do sol da Grécia, ou perfumado pelos mais raros incensos.

$\mathrm{O}$ seu mundo era o mar e era o céu, eram as gaivotas, as estrelas e as constelações, os deuses gregos e os grandes poetas. Era o leite e era o sangue.

Uma enormidade, com certeza. Mas que cabia entre as quatro paredes de um quarto. Muitos quartos, na verdade... Sempre os mesmos? 
Quando começamos a leitura de qualquer poema de Sophia, nunca sabemos aonde o poema irá nos levar. Iniciar um poema sobre o quarto significa a mesma emoção de abrir uma porta fechada (e se o leitor, aqui, se lembrar de Ponge, não será mera coincidência). O que nos aguarda, do outro lado da porta?

Uma surpresa, sem dúvida. Talvez uma musa dedilhando uma harpa, talvez um cubo sobre um jardim de medusas, quem sabe uma flauta com som de Pessanha, ou janela com vista para a Lisboa pintada por Cesário... E muitas outras surpresas, desta vez do outro lado das paredes: o ruído ensurdecedor dos bondes (perdão, dos carros, estamos em Portugal), as árvores da noite que se assemelham a fantasmas, o verdugo, o toiro e a cisterna.

Entre as surpresas de dentro do quarto e as de fora, a presença inefável de um sujeito. Rindo, chorando, sofrendo - vivendo. Enquanto isso, muito lá no alto, o brilho sempre aceso das estrelas...

Mas, chega de conversa, chega de saber de Sophia através de terceiros. Nada será melhor do que o próprio leitor, ele mesmo, ser surpreendido pela vitalidade perene de uma poeta com luz de astro, que não morre nunca. Mesmo quando fala da morte. 


\section{REFERÊNCIAS BIBLIOGRÁFICAS}

ADORNO, T.W. Lírica e sociedade. In: Os pensadores. Trad. de J. L. Grünnewald [et al]. São Paulo: Abril Cultural, 1980. p. 193-208.

ALMEIDA, R. F. S. de. Poesia de Sophia de Mello Breyner Andresen como renomeação das coisas. Dissertação (Mestrado em Literatura Portuguesa). Faculdade de Filosofia Letras e Ciências Humanas, Universidade de São Paulo, São Paulo, 1992.

ALMINO, J. A literatura da cisma. Folha de S. Paulo, São Paulo, 26 set. 1999.

Entrevista disponível na Internet em:

$<$ http://www1.folha.uol.com.br/fsp/mais/fs2609199907.htm>. Acesso em: 10 nov.

2006.

ALVES, I. F. Os poetas sem qualidades na poesia portuguesa recente. In: PEDROSA, C., CAMARGO, M. L. de B. Poéticas do olhar e outras leituras de poesia. Rio de Janeiro: 7 Letras, 2006.

-----De casa falemos. In: SILVEIRA, J. F. da. (org.). Escrever a casa portuguesa. Belo Horizonte: UFMG, 1999.

ANDRADE, E. de. Saudades de Sophia. Relâmpago - revista de poesia. Lisboa, n. 9/10, 2001.

ANDRESEN, S. de M. B. O Búzio de Cós e outros poemas. Lisboa: Caminho, 2004.

----. “A Coisa Mais Antiga”, in Poemas Escolhidos. V. Arêas (introd. e sel.). São Paulo: Companhia das Letras, 2004; p.155.

-----. Obra poética I. $6^{\mathrm{a}}$. ed. Lisboa: Caminho, 2001.

-----. Obra poética III. 4ª ed. Lisboa: Caminho, 1999.

-----. O nu na antigüidade clássica. 3ª . ed. Lisboa: Caminho, 1992.

-----. Obra poética II. Lisboa: Caminho, 1991. 
-----. O rapaz de bronze. Lisboa: Moraes, 1956.

-----. A poesia de Cecília Meireles. Cidade Nova. Coimbra, v. IV, série 6, p. 341-352, 1956.

APOLLINAIRE, 2007. Disponível em http://leo.ifrance.com/meduse.html.

Acesso em 15 mai 2007.

APOLONIA, M. A. F. Transfiguração do real na obra de Sophia de Mello Breyner Andresen (1940-1960). Dissertação (Mestrado em Literatura Portuguesa). Faculdade de Filosofia Letras e Ciências Humanas, Universidade de São Paulo, São Paulo, 1988.

-----. Memória da expansão ultramarina portuguesa em Navegações, de Sophia de Mello Breyner Andresen. Tese (Doutorado em Literatura Portuguesa). Faculdade de Filosofia Letras e Ciências Humanas, Universidade de São Paulo, São Paulo, 1985

APRIL IN PORTUGAL, 2006. Disponível em:

$<$ http://en.wikipedia.org/wiki/April_in_Portugal_(song)> Acesso em: 23 out. 2006.

ARÊAS, V. Sophia: clássica e anticlássica. In: ANDRESEN, S. de M. B. Poemas escolhidos. São Paulo: Companhia das Letras, 2004. p. 15-25.

ARRIGUCCI JR, D. Humildade, paixão e morte: a poesia de Manuel Bandeira. São Paulo: Companhia das Letras, 1990.

AVRIL AU PORTUGAL, 2006. Disponível em http://www.frmusique.ru/texts/g/giraud_yvette/avrilauportugal.htm. Acesso em: 23 out. 2006.

AZEVEDO, L. C. de M. O quarto, figuração do intimismo na poesia de Manuel Bandeira e na de Sophia de Mello Breyner Andresen. Anais do X Congresso Internacional, Associação Brasileira de Literatura Comparada, Rio de Janeiro, 2006. CD-Rom.

-----. O homem moderno aprisionado dentro de si mesmo: pontos de tangência entre a poesia de Francis Ponge e a de Sophia de Mello Breyner Andresen. Comunicação apresentada no I Encontro Paulista de Professores de Literatura Portuguesa, Associação Brasileira de de Professores de Literatura Portuguesa, Faculdade de Filosofia, Letras e Ciências Humanas, USP, São Paulo, 2005. CD-Rom, a sair. 
BACHELARD, G. A psicanálise do fogo. Trad. de P. Neves. $2^{\mathrm{a}}$. ed. São Paulo: Martins Fontes, 1999.

----- A terra e os devaneios do repouso. Trad. de P. N. da Silva. São Paulo: Martins Fontes, 1990.

-----. O ar e os sonhos. Trad. de A. de P. Danesi. São Paulo: Martins Fontes, 1990.

-----. A água e os sonhos. Trad. de A. de P. Danesi. São Paulo: Martins Fontes, 1990.

-----. A poética do devaneio Trad. de A. de P. Danesi. São Paulo: Martins Fontes, 1988.

A poética do espaço. In: BACHELARD, Gaston. O novo espírito cientifico; $A$ poética do espaço. Trad. de R. F. Kuhnen, A. da C. Leal e L. do V. C. Leal. São Paulo: Nova Cultural, 1988 (Os pensadores).

BANDEIRA, M. Poesia completa e prosa. Rio de Janeiro: Nova Aguilar, 1966.

BELCHIOR, M. de L. Itinerário poético de Sophia. Colóquio/Letras. Lisboa, n. 89, p. 36-42, jan. 1986.

BELLINE, A. H. C. Da solidão à solidariedade: uma leitura da obra poética de Sophia de Mello Breyner Andresen. Dissertação (Mestrado em Literatura Portuguesa). Faculdade de Filosofia Letras e Ciências Humanas, Universidade de São Paulo, São Paulo, 1985.

BENJAMIN, W. Paris, capital do século XIX. In: BENJAMIN, W. Sociologia. F. R. Kotke (org.). São Paulo: Ática., 1985. p. 30-43.

BESSA-LUÍS, A. Prazer e glória. Lisboa: Guimarães, 1988.

BIEDERMANN, H. Dicionário ilustrado de símbolos. Trad. de G. P. de Camargo. São Paulo: Melhoramentos, 1993.

BRANDÃO, F. H. P. As fábulas. Vila Nova de Famalicão: Quasi, 2002. 
----.. O triplo nome: Sophia. A Phala. Ed. “Um Século de Poesia”, Lisboa, p. 79-82, dez. 1988.

CAMINHO, 2006. Disponível em $<$ http://html.editorial-caminho.pt $>$. Acesso em: 4 out. 2006.

CAMÕES, L. V. de. Os Lusíadas. F. Da S. Bueno (com.). 11ª . Ed. Rio de Janeiro: Ediouro, 1996.

----.. Lírica completa III. M. de L. Saraiva (pref.) Lisboa: Imprensa Nacional/ Casa da Moeda, 1981.

CANDIDO, A. O direito à literatura. In CANDIDO, A. Vários escritos. $3^{\mathrm{a}}$. ed. São Paulo, Duas Cidades, 1995, p. 235-263.

CARPINEJAR, F. A claridade marítima da poesia de Sophia de Mello Breyner Andresen. Revista Agulha, Fortaleza e São Paulo, n. 40, 2004. Disponível em $<$ http://www.revista.agulha.nom.br/ag40andresen.htm>. Acesso em: 9 out. 2006.

CARVALHO, A. M. de. Sophia, a fada azul. Visão. 8 jul. 2004, p. 112-116. Disponível em $<$ http://files.sapo.pt/turma/Sophia_de_Mello_Breyner_A_Fada_Azul_8Jul04.pdf $>$. Acesso

em: 10 mar. 2007.

CASTRO, E. M. de M. e. O fim visual do século XX e outros textos críticos. Org. de N. B. Gotlib. São Paulo: Edusp, 1993.

CATTANEO, C. V. Introduzione. In: ANDRESEN, S. de M. B. Il nome delle cose. Roma: Portucale, 1983, p. 5-19.

CEIA, C. Iniciação aos mistérios da poesia de Sophia de Mello Breyner Andresen. Lisboa: Vega, 1996.

CIRLOT, J-E. Dicionário de símbolos. Trad. de R. E. F. Frias. São Paulo: Moraes, 1984. 
CISTERNA. In: CORREIA, A. M. et al. (org.) Grande enciclopédia portuguesa e brasileira. Lisboa: Editorial Enciclopédia, 1960. Vol. 6, p. 881.

CHEVAliER, J., GHEERBRANT, A. (org.) Dicionário de símbolos. Trad. (org.) de C. Sussekind. 14 ${ }^{\text {a }}$ ed. Rio de Janeiro: José Olympio, 1999.

COELHO, E. do P. Uma personalidade, um tempo,uma obra. Revista ICALP Instituto de Cultura e Língua Portuguesa,. Lisboa, n. 6, ago./dez. 1986. Disponível em:

< http://www.instituto-camoes.pt/escritores/sophia/sophiaepc.htm > Acesso em 15 set. 2004.

-----. Sophia, a lírica e a lógica. Colóquio/Letras. Lisboa, n. 57, 1980, p. 20-25.

COELHO, J. do P. Irene Lisboa. In: COELHO, J. do P. (org.) Antologia da ficção portuguesa contemporânea. Lisboa: Instituto de Cultura Portuguesa, 1979. p. 37-38.

COHEN, J. M., COHEN, M. J. The Penguin dictionary of quotations. Harmondsworth: Penguin, 1960.

COIMBRA, 2006. Disponível em

$<$ http://www.cdroots.com/tradisom-coimbra.html>. Acesso em: 23 out. 2006.

COSTA E SILVA, A., BUENO, A. (Org.) Antologia da poesia portuguesa contemporânea - um panorama. Rio de Janeiro: Lacerda, 1999.

CUNHA. M. I. B. Luzes e sombras - metáforas da ambivalência na poética de Sophia de Mello Breyner Andresen. Tese (Doutorado em Literatura Portuguesa). Faculdade de Filosofia Letras e Ciências Humanas, Universidade de São Paulo, São Paulo, 1992.

-----. Entre o espelho do mundo e o espelho do texto - introdução à poesia de Sophia de Mello Breyner Andresen. Dissertação (Mestrado em Literatura Portuguesa). Faculdade de Filosofia Letras e Ciências Humanas, Universidade de São Paulo, São Paulo, s/d.

DE LISA, A. Serpenti piumati e profumi di donna. Visual art and visual communication researches. Disponível em $<$ http://www.visualartjournal.net/index.html>. Acesso em: 10 jan. 2007. 
DELILLE, M. M. G. A figura da femme fragile e o mito de Ofélia na lírica juvenil e no Só de Antonio Nobre. Colóquio/Letras. Lisboa, n. 127/128, jan.-jul. 1993, p. 117135.

DEMOUGIN, J. (org.) Dictionnaire des littératures française et etrangères. Paris: Larousse, 1992.

DIBIE, P. O quarto de dormir: um estudo etnológico. Trad. de P. A. N. da Silva. Rio de Janeiro: Globo, 1988.

DUMOUliÉ, C. Medusa (a cabeça de). In: Brunel, P. (org.) Dicionário de mitos literários. Trad. de C. Sussekind [et al]. Rio de Janeiro: José Olympio, 1997, p. 620626.

DURAND, G. As estruturas antropológicas do imaginário. Trad. de H. Godinho. São Paulo: Martins Fontes, 2001.

ELIADE, M. O sagrado e o profano: a essência das religiões. Trad. de R. Fernandes. São Paulo: Martins Fontes, 1992.

FAVRE, Y.-A. Narciso. In: Brunel, P. (org.) Dicionário de mitos literários. Trad. de C. Sussekind [et al]. Rio de Janeiro: José Olympio, 1997, p. 747-750.

FERRAZ, E. Ouvir o poema. Relâmpago. Lisboa, n. 10, p. 31- 48, out. 2001.

Disponível em $<$ http://eucanaaferraz.com.br/ensaio/ensaio_relampago.htm $>$. Acesso em 10 jun. 2007.

FERREIRA, A. B. de H. Novo Dicionário da Língua Portuguesa. Rio de Janeiro: Nova Fronteira, s/d.

FERREIRA, R. “Os Astros Nascem”. Disponível em: $<$ http://alfarrabio.di.uminho.pt/reinaldo/reinaldo2.html\#45>. Acesso em: 23 nov. 2006.

GALHARDO, 2006. Disponível em $<$ http://natura.di.uminho.pt/ jj/musica/html/galhardo-coimbra.html>. Acesso em: 23 out. 2006.

GAMBA, C. Botticelli. Milão: Hoepli, 1936. 
GLUSBERG, J. Moderno/postmoderno. Buenos Aires: Emecé, 1993.

GONZAGA, T. A. Marília de Dirceu. Disponível em:

$<$ http://www.ig.com.br/PAGINAS/NOVOIGLER/livros/marilia_de_dirceu_tomaz_go nzaga/parte1_3.html $>$. Acesso em 10 jun. 2007.

GRAVES, R. Os mitos gregos. Lisboa: Dom Quixote, 1990.

GRIMAL, P. The Penguin dictionary of classical mythology. Trad. para o inglês de A. R. Maxwell-Hyslop. Londres: Penguin, 1991.

GUIMARÃES, F. A poesia contemporânea portuguesa. Vila Nova de Famalicão: Quasi, 2002.

GUIMARÃES, R. Dicionário da mitologia grega. São Paulo: Cultrix, 1995.

GUYER, L. R. Imagística do espaço fechado na poesia de Fernando Pessoa. Trad. portuguesa de A. Hatherly. Lisboa: Imprensa Nacional/ Casa da Moeda, 1982.

HIGHSMITH, P. “O piano dos Steinach”. In HIGHSMITH, P. Nada é o que parece ser. Trad. de C. Magalhães e I. Fonseca. São Paulo: Arx, 2005, p. 195-228.

HORÁCIO, 2007. Disponível em

$<$ http://www.citador.pt/citarios.php?op=2\&sectionid=0\&autoria $=1771 \&$ firstrec $=0>$. Acesso em 10 jun. 2007.

HORTA, M. de L. Poetas portugueses contemporâneos. Recife: Pirata, 1985.

JORGE, L. N. Poesia - 1960/1989. Lisboa: Assírio e Alvim, 1993.

KERENYI K. Os deuses gregos. São Paulo: Cultrix, 1999.

KURY, M. da G. Dicionário de mitologia grega e romana. São Paulo: 1992. 
LANGROUVA, H. C. Sophia de Mello Breyner: transmutação da palavra em poesia. Texto apresentado ao III Colóquio "Discursos e Práticas Alquímicas", Lisboa, 2001.Disponível em: < http://www.triplov.com/sophia/langr_alquimia_3.html $>$ Acesso em: 10 mar. 2007.

-----.Mar-poesia de Sophia de Mello Breyner Andresen: poética do espaço e da viagem. Revista Brotéria. Lisboa, mai.,/jun./jul. 2002. Disponível em <http://www.triplov.com/sophia/helena.html>. Acesso em 9 out. 2006.

LEMPRIERE, J. A classical dictionary. Londres: 1984

LÉVINAS, E. Totalidade e infinito. Lisboa: Edições 70, 1988.

LHOSTE, J. L'homme et sa maison. Paris: NRF, 1972.

LOPES, H. C. O que vi em Portugal. Rio de Janeiro: [s.n.], 1956.

LOPES, S. R. A afirmação silabada. Jornal de Letras. Lisboa, 21 jul. 2004, p. 10-11.

MARINHO, M. F. Sophia de Mello Breyner Andresen: um original cruzamento de tendências. Máthesis, Viseu, n. 10, 2001, p.59-72. Disponível em

$<$ www4.crb.ucp.pt/Biblioteca/Mathesis/Mat10/mathesis10_59.pdf $>$. Acesso em 9 out. 2006.

-----. A poesia portuguesa nos meados do século XX: rupturas e continuidades. Lisboa: Caminho, 1989.

MARTA, E. “Almadilha”. Disponível em $<$ http://www.ciberduvidas.sapo.pt/php/resposta.php?id=16201>. Acesso em: 23 out. 2006.

MARTINS, M. F. 10 anos de poesia em Portugal. Lisboa: Caminho, 1986.

MATOS, M. L. S. de. Os itinerários do maravilhoso: uma leitura dos contos para crianças de Sophia de Mello Breyner Andresen. Porto: Porto Editora, 1993.

MEDICI, 2006. Disponível em <http://www.fvza.org/medici.html>. Acesso em: 15 set. 2006. 
MEIRELES, C. Antologia poética. $2^{\mathrm{a}}$. ed. Rio de Janeiro: Editora do Autor, 1965.

MELO NETO, J. C. Antologia poética. 2ª ed. Rio de Janeiro: Sabiá, 1973.

MESQUITA, Z. R. C. de. A insigne dor humana - presença de Schopenhauer na poesia de Camilo Pessanha. Dissertação (Mestrado em Literatura Portuguesa). Faculdade de Filosofia Letras e Ciências Humanas, Universidade de São Paulo, São Paulo, 1999.

MISTÉRIO. In: CORREIA, A. M. et al. (org.) Grande enciclopédia portuguesa e brasileira. Lisboa: Editorial Enciclopédia, 1960. Vol. 17, p. 398.

MONTAIGNE, M. E. de. Ensaios - Da vaidade. Disponível em: $<$ http://

www.citador.pt/pensar.php?op=10\&refid=200411211626>. Acesso em: 3 out. 2006.

MOREIRA, M. S. de G. Os cabelos da medusa: tricotilomania e fetichismo. Aeternus. Disponível em <http://www.aetern.us/article49.html>. Acesso em 15 mai. 2007.

MORGENTHAU, H. J.; PERSON, E. As raízes do narcisismo. Diálogo, Rio de Janeiro, v. 14, n. 1, s/d.

MOUTINHO, M. A arquitetura popular portuguesa. Lisboa: Estampa, 1979.

NOBRE, A. Só. 13ª ed. Porto: Tavares Martins, 1966.

-----. Despedidas. Porto: Imprensa Moderna, 1945.

OPHÉLIE. In: Dictionnaire des personnages de tous les temps et de tous les pays. Paris: Robert Laffont, 1992, p. 730.

PÂRIS-MONTECH, C. L'Imaginaire de Camilo Pessanha. Résonances fin-de-siècle et hantises individuelles, Lisboa: Fundação Calouste Gulbenkian, 1997.

PEIXOTO, M. H. F. Sophia, a tecelã do mundo: uma leitura da poética de Sophia de Mello Breyner Andresen. Dissertação (Mestrado em Literatura Portuguesa). 
Faculdade de Filosofia Letras e Ciências Humanas, Universidade de São Paulo, São Paulo, 1992.

PEREC, G. Espèces d'espaces. Paris: Galilée, 1974.

-----. Un homme qui dort. Paris: Denoel, 1967.

PEREIRA, E. Uma casa para ler e deitar. In: SILVEIRA, J. F. da (org.). Escrever a casa portuguesa. Belo Horizonte: UFMG, 1999, p. 493-499.

PERROT, M. Maneiras de morar. In: PERROT, M. (org.). História da vida privada. Vol. 4. São Paulo: Companhia das Letras, 1992, p. 307-323.

PESSANHA, C. Clepsydra. P. Franchetti (ed. crítica). Lisboa: Relógio D’Água, 1995.

PESSOA, F. Para a memória de António Nobre. A Galera. Ed. comemorativa sobre Antonio Nobre. Coimbra, 25 fev. 1915. Artigo disponível na Internet, em

$<$ http://interregno.blogspot.com/2006_05_01_archive.html>. Acesso em 15 jul. 2007.

-----.. Mensagem. F. C. Matos (ed.). 2a . ed. Lisboa: Assírio e Alvim, 2000.

PINSENT, J. Mitos e lendas da Grécia antiga. Trad. de O. M. Caputo. São Paulo: Melhoramentos/ Edusp, 1976.

PONGE, F. O partido das coisas. I. A. NEIS, M. PETERSON (org.). São Paulo: Iluminuras, 2000.

QUENTAL, A. de. Sonetos. 4a . ed. Lisboa: Sá da Costa, 1972.

RAPOPORT, A. Pour une anthropologie de la maison. Paris: Dunod, 1972.

REIS, C. A poesia portuguesa na posteridade do modernismo. Metamorfoses. Rio de Janeiro, n. 6, 2005, p. 111-113.

REZENDE, A. Phrases e curiosidades latinas. s/l., s/d. 
REZENDE, J. N. A simbolização nas imagens poéticas de Cecília Meireles e Sophia de Mello Breyner Andresen: tempo e espaço. Tese (Doutoramento em Literatura Portuguesa). Faculdade de Filosofia Letras e Ciências Humanas, Universidade de São Paulo, São Paulo, 2006.

RIBEREITE, J. Encontro de Sophia com Ricardo Reis "À Sombra das Palavras". Comunicação apresentada ao IV Congresso Internacional da Associação Portuguesa de Literatura Comparada. Disponível em:

$<$ http://www.eventos.uevora.pt/comparada/VolumeIII/ENCONTRO\%20DE\%20SOP HIA\%20COM\%20RICARDO\%20REIS.pdf> Acesso em 25 out. 2006

RILKE , R. M. Poemas I, pref., sel. e tradução de Paulo Quintela. 2a ed. Coimbra: Atlântida, 1967.

ROCHA, C. Sophia de Mello Breyner Andresen: poesia e magia. Colóquio/Letras. Lisboa, n. 132/133, 1994, p. 165-182.

-----.Máscaras de Narciso - estudos sobre a literatura autobiográfica em Portugal. Coimbra: 1992.

RÓNAI P. Dicionário universal Nova Fronteira de citações. Rio de Janeiro: Nova Fronteira, 1985.

ROZÁRIO, D. Palavra de poeta - Portugal. Rio de Janeiro: Civilização Brasileira, 1994.

SCRAMIM, C. G. A presença do helenismo de Ricardo Reis e da visão do mundo grego clássico na poesia de Sophia de Mello Breyner Andresen. Dissertação (Mestrado em Letras). Centro de Ciências Humanas Letras e Artes, Universidade Estadual de Maringá, Maringá, 2006. Disponível em: $<$ http://dominiopublico.mec.gov.br>. Acesso em: 10 mar. 2007.

SERRA, P., SILVESTRE, O. M. (org.) Século de ouro: antologia crítica da poesia portuguesa do século XX. Braga: Angelus Novus / Cotovia, 2002.

SILVEIRA, J. F. Da. Da idade da pedra - Fiama poeta. Metamorfoses, Rio de Janeiro, n. 6 , ago. 2005, p.61-72.

-----. Verso com verso. Coimbra: Ângelus Novus, 2003. 
-----. (org.). Escrever a casa portuguesa. Belo Horizonte: UFMG, 1999.

SOARES, P. P. A dama branca e suas faces: a representação iconográfica da tuberculose. História, ciência, saúde - Manguinhos. Rio de Janeiro, vol. 1, n. 1, jul./ out. 1994, p. 127-134. Disponível em:

$<$ http://www.scielo.br/scielo.php?script=sci_arttext\&pid=S0104-

59701994000100012> Acesso em: 10 jan. 2007.

STEINBERG, V. "No Poema": um paradigma da tessitura poética de Sophia de Mello Breyner Andresen. 2006. Dissertação (Mestrado em Literatura Portuguesa). Faculdade de Filosofia Letras e Ciências Humanas, Universidade de São Paulo, São Paulo, 2006.

SUPINO, I. B. Sandro Botticelli. 4a . ed. Roma: Formiggini, 1924.

TARUGA, 2006. Disponível em $<$ http://www.flickr.com/photos/joe_taruga/44125125/in/set-72157594289259510/>. Acesso em: 30 out. 2006.

TAVARES, M. de S. E ela dança. Público, 1999. Disponível em $<$ http://www.triplov.com/sophia/poemas/miguel_sousa_tavares.htm> Acesso em: 15 out. 2006.

TEIXEIRA, G.M. “Dansa”. Disponível em: < http://www.stormmagazine.com/novodb/arq.php?arq $=1 \&$ edicao $=19 \% 20$ -

\%20Setembro/Outubro\%202004>. Acesso em: 5 nov. 2006.

TEIXEIRA, J. L. A casa por fabricar: uma leitura do poema "Andaime" de Fernando Pessoa. Disponível em: < http://alfarrabio.di.uminho.pt/vercial/letras/ensaio12.htm>. Acesso em: 2 nov. 2006.

THIBAUD, R-J. Dictionnaire de Mythologie et de Symbolique Grecque. Paris: Dervy, 1996.

TORRES, A. P. Sophia de Mello Breyner Andresen também no caminho para o concreto. In: TORRES, A. P. Poesia: programa para o concreto. Lisboa: Ulisseia, 1966. p. 28-37.

TORRES, U. L. A dança dos pensamentos. São Paulo: 1979. 
VASCONCELOS, J. C. Sophia: a luz dos versos. Jornal de Letras. Lisboa, n 468, 25 jun. 1991. p. 8-11.

VENTURI, 1. Botticelli. 2a. ed. Londres: Phaidon, 1974.

VESPUCCI, S. Disponível em: < http://en.wikipedia.org/wiki/Simonetta_Vespucci> Acesso em: 15 set. 2006. 
ANEXOS

ANEXO A - A tília na mitologia grega.

A tília, informa o dicionário de Aurélio Buarque de Holanda Ferreira, é "uma árvore ornamental da família das tiliáceas (Tília cordata), nativa e cultivada na Europa" (FERREIRA, s/d, p. 1388).

$\mathrm{Na}$ mitologia grega, encontramos pelo menos duas lendas ligadas a essa árvore. Uma refere-se à ninfa Filira, filha de Oceano, da qual Crono se enamorou. Como conta Robert-Jacques Thibaut, em seu Dictionnaire de Mythologie et de Symbologie Grecque, Crono "transformou-se em cavalo quando sua esposa Réia [descobriu a traição dele]. Da união [de Filira com Crono] nasceu o centauro Quíron, porém, amedrontada, Filira pediu aos deuses que a metamorfoseassem e eles a converteram numa tília” (THIBAUD, 1996, p. 592).

Outra lenda conta a história do casal de camponeses frígios Báucis e Filêmon. Reproduzimos a versão de Mário da Gama Kury, como aparece no Dicionário de mitologia grega e romana:

Báucis [foi uma] mulher humilde da Frigia, casada com Filêmon, um camponês tão pobre como a sua companheira. Um dia Zeus e Hermes, disfarçados em viajantes, percorriam a localidade onde os dois moravam e, enquanto os outros habitantes da região recusavam-se a acolhê-los, Báucis e Filêmon os receberam hospitaleiramente. Revoltados com a maioria dos moradores do local, os deuses provocaram um dilúvio, do qual somente se salvaram o casal e sua morada, transformada em seguida num templo. A única pretensão de Filêmon e Báucis, quando os deuses lhes perguntaram o que desejavam, foi a de chegarem juntos ao fim da vida (KURY, 1992, p. 56).

O fim da história do casal é melhor contado por Ruth Guimarães, em seu Dicionário de mitologia grega: "[O casal viveu] por muitos anos ainda e, certo dia, [os deuses Zeus e Hermes transformaram] Báucis numa tília e Filêmon num carvalho. E ali [defronte do templo] ficaram para sempre um ao lado do outro" (GUIMARÃES, 1993, p. 86). 
ANEXO B - "Os Astros Nascem".

Este é o poema “Os Astros Nascem”, de Reinaldo Ferreira, do livro Poemas, de 1960:

Os astros nascem,

Crescem e morrem

Sem aflição,

Por isso correm

Sem que perguntem

P'ra onde vão.

O fácil espaço

Foi-lhes materno

Ventre fecundo;

Nasci num quarto,

Nasci dum parto

E foi magoando

Que vim ao mundo.

Nasci rasgando

Quem me sonhava

Antes que mesmo

Me concebesse;

Não sei dum astro,

Tão impiedoso,

Que ao espaço agravos

Tamanhos desse!

Nasci rompendo

Quem me continha

No grácil ventre

Desfigurado,

Como um sacrário

Vaso sagrado!

Mãos impacientes

De me tocarem

Logo estendia

Quem eu magoava

E ensangüentava

Quando nascia!

Nascença de astros

Não tem valor:

Que o fácil espaço

Pare-os sem dor. (FERREIRA, 2006) 


\section{ANEXO C - Cassiopéia, Medusa, Pégaso.}

Cassiopéia é o nome de uma constelação do hemisfério norte celeste, próxima do pólo norte celeste, com cerca de 30 estrelas visíveis a olho nu. Entre as constelações vizinhas, estão Cefeu, Andrômedra e Perseu. A figura formada pelas estrelas de Cassiopéia lembra alguém sentado num trono, só que de cabeça para baixo. Para os gregos, isso representava a punição por um crime severo e logo associaram essa constelação ao mito de Cassiopéia, a vaidosa esposa de Cefeu, rei da Etiópia. A mitologia conta que Cassiopéia comparou sua beleza à das Nereidas, filhas de Posêidon. Estas não se conformaram e pediram para que seu pai as vingasse. Então, ele enviou o monstro marinho Cetus (besta similar a uma baleia e também representado no céu por uma constelação, Cetus, a Baleia, localizada no equador celeste), para destruir o reino de Cefeu. Para acalmar a ira do deus dos mares, um oráculo sugeriu que Cefeu e Cassiopéia acorrentassem sua filha Andrômeda a um rochedo, para que o monstro a devorasse.

Aí entra o herói Perseu, vindo do País dos Hiperbóreos, onde havia decapitado a Górgona Medusa, monstro terrível com cobras no cabelo e um olhar que transformava em pedra quem a encarasse. Perseu conseguiu essa façanha olhando não diretamente para a Medusa, mas para o reflexo dela em seu escudo, que havia sido fornecido pela deusa Atena. Em seguida, com uma foice, emprestada por Hermes, cortou a cabeça da Górgona Medusa e a jogou numa rede, conseguida através da Ninfa do Vento do Norte. Do sangue da Medusa, derramado sobre a areia, nasceu o cavalo alado Pégasus; as gotas desse mesmo sangue, ao caírem no mar, formaram os animais celenterados (medusas, corais, pólipos, anêmonas-do-mar, etc.).

Ao voltar para casa, Perseu encontrou Andrômeda amarrada no rochedo. Quando Cetus se levantou das profundezas, Perseu mostrou-lhe a cabeça da Medusa, transformando o monstro em pedra e conseguindo, assim, libertar Andrômeda. Para mais informações a respeito da constelação de Cassiopéia e dos mitos gregos a ela relacionados, consultar, entre outros, o Dictionnaire de mythologie et de symbologie grecque, de Robert-Jacques Thiabaud (THIBAUD, 1996). Sobre a presença dos mitos gregos na poesia de Sophia, ver, também, o livro de Carlos Ceia, Iniciação aos mistérios da poesia de Sophia de Mello Breyner Andresen (CEIA, 1996). 


\section{ANEXO D - Almadilha.}

A professora portuguesa Eunice Marta estabeleceu uma longa teoria, para explicar o termo "almadilha", utilizado por Sophia no texto "As Grutas": "almadilha [...] não figura nos dicionários [editados em Portugal] mais reconhecidos, nem no Dicionário de Morais, nem no de Cândido de Figueiredo, nem no da Academia das Ciências de Lisboa, nem no Dicionário etimológico da língua portuguesa de José Pedro Machado, do que se infere que tal palavra é uma criação poética de Sophia, realidade-desvio que a própria liberdade literária/artística permite a todo o artista, pois pela arte se acede ao estatuto privilegiado da diferença".

"Se [formos] estabelecer uma analogia com o que aconteceu com a criação poética usada por Fernando Pessoa, no poema 'D.Dinis', de Mensagem - [o termo] marulho - misto de mar e de barulho, fórmula que cria e passa um efeito sonoro muito agradável, provocando uma série de sensações, podemos ousar colocar [...] almadilha ao mesmo nível, procurando descodificar/desvendar as possíveis leituras que daí

poderemos fazer, partindo das associações que tal termo nos evoca. É importante também assinalar que o próprio texto 'As Grutas' nos remete para essa idéia da criação de novas palavras, poucas linhas antes do aparecimento de almadilha[:] 'Sem dúvida um novo mundo nos pede novas palavras, porém é tão grande o silêncio e tão clara a transparência, que eu muda encosto a minha cara na superfície das águas lisas como um chão' [segundo o que Sophia escreveu, grifo da professora Marta]”.

“[...] O termo almadilha [deve] ser lido/interpretado à luz do texto. Não podemos negligenciar a presença de, pelo menos, duas dimensões: por um lado, a do domínio do sonho/onírico [em oposição à] do real, assim como a do universo marinho ('águas lisas') e do terreno ('chão'). A presença desses elementos indicia - e talvez se possa mesmo dizer que legitimiza - algo que remeta para esses universos vários. Caberá, então, ao leitor ler as conotações que a polissemia dessa palavra poderá permitir. Por exemplo, [...] inferir que esse termo é um misto de um termo de origem árabe almandrilha , que está associado ao mar - armação de pesca - e de armadilha. Um e outro termo apontam para a idéia de rede, de algo dissimulado, com [o qual] se pretende apanhar algo. Não estará a narradora ela própria presa nas redes do seu sonho, ou queria ficar presa nas grutas que lhe permitem mergulhar nas origens? São as liberdades que o texto literário permite!” (MARTA, 2006) 


\section{ANEXO E - "Coimbra", "Avril au Portugal" e "Uma Casa Portuguesa"}

A canção "Coimbra", embora escrita originalmente na década de 30, só alcançou alguma repercussão em Portugal a partir de 1947, quando apareceu no filme Capas negras, de Armando Miranda, tendo se tornado extremamente popular três anos depois, ao ser gravada por Amália Rodrigues (1920-1999). Segundo consta, a transformação de "Coimbra" em "Avril au Portugal", sua versão em francês, ocorreu por influência direta de Amália, que teria sugerido sua inclusão no repertório de Yvette Giraud. Ou, como lemos na Internet:

Através de uma complexa articulação de símbolos, gostos e interesses, \{0 mote Abril em Portugal] tornou-se um símbolo turístico de grande importância. A propaganda governamental [da ditadura de Salazar] aproveitou isso [para a criação de] panfletos e, em 1955, [produziu] um filme de média-metragem, Abril em Portugal, com Amália interpretando a canção". (COIMBRA, 2006)

Por causa do sucesso internacional de "Avril au Portugal", em 1966, o dia 20 de abril foi instituído em Portugal como Dia Nacional do Turismo. Para mais informações, consultar (AVRIL AU PORTUGAL, 2006) e (APRIL IN PORTUGAL, 2006).

De certa forma, o destino político de "Coimbra", a partir de sua transformação em "Abril em Portugal", repetiu o ocorrido com a igualmente famosa "Uma Casa Portuguesa", também do repertório de Amália Rodrigues, com música de V. M. Sequeira e Artur Fonseca, letra do já citado poeta Reinaldo Ferreira, aquele que passou grande parte de sua vida em Moçambique. O professor Jorge Fernandes da Silveira, em "Casas de Escrita", texto de apresentação a Escrever a Casa Portuguesa, lembra isso (apesar de incluir o adjetivo "pequena" à "casa portuguesa", ele deve estar se referindo à mesma canção) ao comentar, ironicamente, a queda de Salazar de uma cadeira, em 1968, acidente que provocou sua morte, dois anos depois:

Lusitanamente falando, algumas ditaduras caem de podre da cadeira.[...] O acidente, que depois de dois anos de paralisia leva o todo poderoso Sr. Prof. Primeiro Ministro à morte, foi parodiado em prosa e verso. "A pequena casa portuguesa" - de acordo com a retórica do fascismo , imagem ideal, (irrealista segundo Eduardo Lourenço) de um país feliz de viver imobilizado em seu sonho imperial saudosista à margem de uma Europa obrigada a questionar seu passado colonialista - como se desfamiliarizando os seus objetos, ataca fatalmente o seu dono". (SILVEIRA, 1999, p. 13; grifo do autor) 
Seguem as letras completas de "Coimbra", tanto a versão original em português, de José Galhardo, como a tradução para o francês, "Avril au Portugal”, de Jacques Larue. (Há uma versão em inglês, "April in Portugal”, aqui não incluída, com letra de Jimmy Kennedy.)

Completando este anexo, "Uma Casa Portuguesa", de Reinaldo Ferreira.

\section{"COIMBRA"}

Coimbra é uma lição

de sonho e tradição (Refrão)

O lente é uma canção e a lua, a faculdade.

O livro é uma mulher,

só passa quem souber,

E aprende-se a dizer "saudade".

Coimbra do Choupal, ainda és capital

Do amor em Portugal, ainda...

Coimbra, onde uma vez, com lágrimas se fez

A história dessa Inês, tão linda.

(Refrão)

Coimbra das canções, tão meiga que nos pões

Os nossos corações a nu...

Coimbra dos doutores, pr'a nós os teus cantores,

A fonte dos amores és tu.

(Refrão) (GALHARDO, 2006)

\section{“AVRIL AU PORTUGAL"}

Je vais vous raconter

Ce qui m'est arrivé

Sous un ciel où l'été

S'attarde

Histoire d'amoureux

Voyage aventureux

Que pour les jours heureux

Je garde

Un grand navire à quai,

La foule débarquait

Deux yeux sous des bouquets

Regardent

L'amour devait rôder

Puisqu'on s'est regardés

Et que mon cœur s'est mis à chanter ...

Avril au Portugal,

A deux c'est idéal,

Là-bas si l'on est fou, 
Le ciel l'est plus que vous,

Pour un sentimental

L'amour existe t-il

Ailleurs qu'au Portugal

En Avril.

Le soir sous mes yeux clos

Glissant au fil de l'eau

Je vois par le hublot

La rive

Des voiles de couleur

De lourds parfums de fleurs

Des chants de bateleurs

M'arrivent...

Tout ça berce mon cœur

D'un rêve de bonheur

Dont les regrets ailleurs

Me suivent,

L'amour devait savoir

En nous suivant le soir

Que j'aimerais un jour la revoir...

Avril au Portugal,

A deux c'est idéal,

Là-bas si l'on est fou,

Le ciel l'est plus que vous,

Mais sans penser à mal

Son cœur attendra t-il

Que j'aille au Portugal,

En avril. (AVRIL AU PORTUGAL, 2006)

\section{"UMA CASA PORTUGUESA"}

Numa casa portuguesa

fica bem

pão e vinho sobre a mesa.

Quando à porta humildemente

bate alguém,

senta-se à mesa co'a gente.

Fica bem essa franqueza,

fica bem,

que o povo nunca a desmente.

A alegria da pobreza

está nesta grande riqueza

de dar, e ficar contente.

Quatro paredes caiadas, um cheirinho á alecrim,

um cacho de uvas doiradas, duas rosas num jardim, um São José de azulejo sob um sol de primavera, uma promessa de beijos

dois braços à minha espera.

É uma casa portuguesa, com certeza! 
É, com certeza, uma casa portuguesa!

No conforto pobrezinho

do meu lar,

há fartura de carinho.

A cortina da janela

é o luar

mais o sol que gosta dela...

Basta pouco, poucochinho p'ra alegrar

uma existéncia singela...

É só amor, pão e vinho

e um caldo verde, verdinho

a fumegar na tijela. (SILVEIRA, 1999, p.383) 
ANEXO F - "Dansa".

Incluímos, aqui, o poema "Dansa", de Gonçalo M. Teixeira, escrito em 2004, logo após a morte de Sophia:

Tem $\mathrm{S}$ a palavra, pois certas curvaturas marcadas no mundo exigem alterações de grafia.

$\mathrm{O}$ traço imprevisto obriga a parar a meio;

à paragem insólita chamarás insólito movimento.

E ficarás contente. (TEIXEIRA, 2006) 